OECD Economics Department Working Papers No. 67

\title{
Saving Trends \\ and Behaviour in OECD \\ Countries
}

\author{
Andrew Dean, \\ Martine Durand, \\ John Fallon, \\ Peter Hoeller
}

https://dx.doi.org/10.1787/006737401012 


\title{
OECD \\ DEPARTMENT \\ OF ECONOMICS AND STATISTICS
}

\section{WORKING PAPERS}

No.67 SAVING TRENDS AND BEHAVIOUR IN OECD COUNTRIES

by

\author{
Andrew Dean, \\ Martine Durand*, \\ John Fallon * and \\ Peter Hoeller \\ (General Economics Division)
}

June 1989

Ms. Durand is now in Country Studies I Division.

Mr. Fallon is a member of Economic Prospects Division.

(0)ED

丽角晋

(0) हCD 



\title{
ECONOMICS AND STATISTICS DEPARTMENT
}

\section{VORKING PAPERS}

\begin{abstract}
This series of Horking Papers is designed to make available, to a wider readership, selected studies which the Department has prepared for use within OECD. Authorship is generally collective, but main individual authors are named.

Comment on the Papers is invited, and may be sent to OECD, Department of Economics and Statistics, 2 rue Andre Pascal, 75775 Paris Cedex 16, France. Additional copies of the Papers on a limited basis can be forwarded on request.
\end{abstract}

ORGANISATION POR ECONOMIC CO-OPERATION AND DEVELOPHENT

Copyright OECD, 1989 
National saving ratios are generally lower now than in the $1960 s$ or 1970s. This paper first reviews developments in national and international saving and investment trends in OECD countries since the 1960s. It then examines sectoral saving trends and considers the links between them. There are seen to be important offsets between government and private sector saving and, within the latter, between the business sector and households, so that national and private saving rates tend to be more stable than their component parts. The paper looks in particular at the reasons lying behind the volatile behaviour of household saving in certain countries in recent years.

Les niveaux des taux d'épargne nationaux sont généralement plus bas aujourd'hui que dans les années 60 et 70 . Cet article présénte les évolutions de 1'épargne et de l'investissement dans les pays de l'oCDE depuis les années 60 . Il examine ensuite les tendances des taux d'épargne dans les différents secteurs de l'économie et les relations entre les évolutions de ces divers taux. En particulier, il apparait qu'il existe des compensations entre I'épargne publique et l'épargne privée et au sein de l'épargne privée entre l'épargne des entreprises et celle des ménages. Ainsi, les taux d'épargne nationaux et privés ont tendance à être plus stable que leurs composantes. Cet article examine en outre les facteurs explicatifs de l'évolution particulière de l'épargne des ménages dans un certain nombre de pays au cours des dernières années. 
NO.67 SAVING TRENDS AND BERAVIOUR IN OECD COUNTRIES

by

\author{
Andrew Dean, \\ Martine Durand, \\ John Fallon and \\ Peter Hoeller
}

June 1989

The authors would like to acknowledge the comments and suggestions of Derek Blades, Robert Hagemann, Kenichi Kawasaki, Jeffrey Shafer, Kumiharu Shigehara and other colleagues in the Economics and Statistics Department. They are also grateful to Valérie Barca, Marie-Christine Bonnefous, Anick Lotrous and Chantal Nicq for statistical assistance and to Jackie Gardel for expert typing. 
TABLE OF CONTENTS

$\underline{\text { Page }}$

INTRODUCTION AND SUMMARY 6

I. TRENDS IN NATIONAL SAVING AND INVESTMENT 8

A. Declining saving and investment rates 8

B. Should lower rates of saving and investment be a concern? 8

i) Saving and investment choices over time 8

ii) The international dimension $\quad 10$

II. GOVERNMENT SAVING AND DISSAVING 12

III. RRIVATE SECTOR SAVING

A. Overall trends $r$

B. Business saving 15

C. Household saving $\quad 15$

i) The rise and fall of household saving 15

ii) Is household saving being measured "correctly"? 16

iii) Why do households save and can inter-country $\begin{array}{ll}\text { differences be explained? } & 17\end{array}$

iv) Unanticipated inflation and uncertainty 19

v) Functional income distribution $\quad 20$

vi) The broader picture; personal net worth and debt 20

vii) Tax structures and their influence on household saving 22

viii) The interaction of financial market liberalisation and
tax distortions

$\begin{array}{lr}\text { IV. CONCLUSIONS } & 24\end{array}$

$\begin{array}{lr}\text { Notes } & 27\end{array}$

$\begin{array}{ll}\text { References } & 31\end{array}$

Annexes I: Statistical annex 67

II: Saving, investment and international capital flows 72

III: Measurement issues relating to household saving 78 
1. Net and gross national saving ratios 36

2. Relation between national saving and investment ratios 37

3. Government saving and dissaving 38

4. Public sector claims on private saving 39

5. Net and gross private saving ratios 40

6. Variation of saving ratios 41

7. Business saving 42

8a. Demographic and social factors influencing household saving 43

8b. Synthetic indicator for cross-country differences in saving 44

9. Income distribution 45

10. Taxation of housing 46

11. Tax wedges for housing investment 47

12. Taxation of consumer purchases 48

CHARTS

A. Trends in national saving and investment rates 49

B. Real gross fixed investment 52

C. External assets and liabilities 53

D. Gross saving ratios: recent trends and outlook 54

E. Wealth/GNP ratios $\quad 57$

F. Net and gross household saving ratios 58

G. Inflation-adjusted gross household saving ratios 61

H. Gross household saving, net worth and debt/income ratios 62

\section{AMREX TABIES}

A1 Saving and investment ratios by country and sector

A2 The relation between savings and investment ratios:

a summary of earlier studies 


\section{SAVING TRENDS AND BEHAVIOUR IN OECD COUNTRIFS}

\section{INTRODUCTION AND SUMOARY}

National saving and investment rates in most OECD economies have declined in the last two decades. This has led to concern in some countries about the adequacy of national saving and investment. Lower rates of investment have been linked to the considerable slowing of the growth of potential output while demographic and environmental factors have been raised as other reasons suggesting the need for higher saving and investment. Furthermore, current-account imbalances associated with disparities between national saving and investment rates in individual economies have become a major concern for policy-makers during the $1980 \mathrm{~s}$.

Concern about low rates of investment has been more pronounced recently because many of the OECD economies are at or moving towards degrees of capacity utilisation that may make faster capital accumulation a crucial factor for sustained non-inflationary growth. In addition there has been an especially rapid decline in household saving rates in some countries during the 1980s. The paper, while it raises issues about saving and investment at a national and even global level, focuses on the saving behaviour and net worth and debt positions of the household sector.

The paper begins with a summary of the main facts about saving and investment, which provides a more detailed "signposting" of the structure of the paper. A brief description of trends in national saving and investment rates and a discussion of whether saving/investment gaps should be of concern in a world of increasingly integrated financial markets is presented in Section I. The role of government saving and dissaving is then assessed in Section II. The rest of the paper then looks at trends in private sector saving rates, mentioning first, why it is useful to consider the private sector as a whole, and then focusing mainly on household saving (Section III).

Summary of the main facts

National saving and investment rates in OECD countries have in general been lower in the $1980 \mathrm{~s}$ than in the $1960 \mathrm{~s}$ or $1970 \mathrm{~s}$, though disparities between countries have remained large. Measures of gross saving and investment have fallen by less than net measures, depreciation having become more important (Section I.A).

Saving and investment decisions by the private sector are considered in a framework of intertemporal optimisation. Although there is no necessary reason to believe that the small trend declines in national saving and investment rates indicate inadequate saving or investment, recent pressures on capacity may suggest the need for continuing high investment while various distortions, especially on the tax side, may be leading to a sub-optimal allocation of resources (Section I.B).

The strong covariation between national saving and investment rates which was found by Feldstein and Horioka (1980) and others has been reduced 
substantially, the influence of international financial liberalisation in the 1980 sacilitating the large capital flows necessary to sustain recent saving/investment gaps in many countries (Section I.B).

Reductions in government saving since the $1960 \mathrm{~s}$ have been an important factor contributing to the decline in national saving and investment. While there are a number of ways in which changes in government saving may induce offsetting changes in private saving, a complete offset seems to have been far from the norm. Only in countries with very high government debt/GNP ratios is there evidence for something close to "Ricardian equivalence". Changes in government expenditure programmes may also affect private saving, even when. they are financed by current taxation, and may therefore influence overall national saving. This is especially important for the areas of pension, health and education policies, where the design of programmes may have significant effects on the private sector's incentives to save (Section II).

Private sector saving rates have exhibited greater stability over time than have the component household and business rates. One implication is that households do see through the "corporate veil", although empirical work usually indicates offsets that are far from complete (Section III.A).

Business saving is strongly related to profit developments. The sharp recovery in profits since the early 1980 s has boosted business saving and considerably increased the self-financing of business investment (Section III.B).

Household saving ratios rose almost everywhere in the 1970s. In the 1980s, they have declined markedly in almost all countries to levels mostly similar to those in the $1960 \mathrm{~s}$ but in some cases even lower. The 1970s "bulge" in saving ratios is a common feature in all OECD countries; it is less significant if adjustment is made for inflation. Other adjustments, such as treating consumer durables as investment, affect the levels of saving ratios but not in general the trends. Demographic factors are important in explaining inter-country disparities in saving ratios (Section III.C).

Household net worth has increased strongly since the 1970 s in several OECD countries and has allowed saving rates to decline without any deterioration in wealth/income positions (Section III.C.vi)). The rise in net worth can largely be attributed to the rise in the value of housing and equities (notwithstanding the stockmarket crash). Meanwhile debt/income ratios have risen sharply, and in many cases this has been associated with financial market liberalisation. The interaction of more readily-available finance, favourable tax treatment of housing and rising property values has encouraged borrowing and may have led to a misallocation of resources. In the context of rising interest rates and some easing in property values there has been concern about the sustainability of debt.

Tax structures are shown to be an important influence on household saving decisions and seem likely in many cases to lead to important distortions (Section III.C.vii)). Although there have been tax reforms in many countries in recent years which have reduced such distortions, those which remain may have interacted with financial market liberalisation in unfortunate ways, raising the important issue of unfinished business in the area of structural reform (Section III.C.viii)). 


\section{TRENDS IN MATIONAT, SAVING AND INVESTMENT}

\section{A. Declining saving and investment rates}

National saving and investment rates differ considerably across OECD countries, with a striking persistence of large disparities between countries (Chart A). A common feature, however, is that in almost all countries the shares of saving and investment in GNP have declined since the $1960 \mathrm{~s}$.

For the OECD area as a whole, the average ratio of gross national saving to GNP fell by 3 percentage points between 1960-70 and 1981-87 while the decline of gross national investment relative to GNP was about 2 percentage points. The largest falls have occurred in continental European countries and Australia, the smallest declines (or even rises) in the United Kingdom, Canada, Finland, Ireland, New zealand, Portugal and Switzerland. While gross national saving rates in the United States and Japan have both fallen by 3 to 4 percentage points (Table 1), the investment rate in Japan has fallen by about 6 percentage points and in the United states, albeit from a much lower level, hardly at all. Hence a net surplus of saving has emerged in Japan and the reverse has occurred in the United States.

The fall in net saving and investment in relation to net national product has generally been more pronounced, reflecting a rise in the depreciation of fixed capital. For the OECD area this amounted on average to 60 per cent of gross national investment in the $1980 \mathrm{~s}$ compared with 40 per cent in the 1960s. Between the $1960 \mathrm{~s}$ and $1980 \mathrm{~s}$ net rates of national saving and investment for the OECD area have thus fallen by more than gross rates -- by 6 and 5 percentage points respectively, compared with 3 and 2 percentage points respectively for gross saving and investment rates. Although the net figures would seem to indicate a more serious decline, with a smaller addition to the capital stock, the data on capital consumption are notoriously unreliable so that it is often felt more prudent to focus on the gross measures (1). Irrespective of the precise measure used, however, there does seem to have been a decline in national saving and investment rates in most OECD countries since the 1960 s.

\section{B. Should lower rates of saving and investment be a concern?}

\section{i) Saving and investment choices over time}

Saving and investment decisions reflect intertemporal choices about consumption and production. Hence low saving rates, for instance, which are a current matter of concern in some countries, are in part a reflection of individuals! rates of time preference -- in this case a preference for current consumption. If low saving rates in a country mean that there is not sufficient national saving to finance the desired national investment, then should this cause concern, especially if other countries seem willing to cover any gap?

The rate of saving by consumers and companies reflects private sector decisions which are a normal feature of the operation of markets. However, private sector decisions are made against a background of government policy, 
past and present, which may give rise to distortions and sub-optimality of one sort or another. The private sector may be deciding how much to save in the light of individual rates of time preference, taking into account the government's own saving position (Section II), but distortions introduced by policies may mean that those decisions are not the optimal ones from the national viewpoint. On these arguments, the role of government should not be to worry about the level of saving and investment, per se, but to worry about whether its own activities -- its own claims on resources but more importantly the structure of tax and expenditure -- are unduly distorting the private sector's saving and investment decisions. Pertinent questions about the role of government would include consideration of the level of government saving, the interaction of taxation changes with financial liberalisation, social security policy and the effect of tax structures on the saving decisions of firms and households, issues taken up in sections II and III below.

In an open economy, the level of national investment may not be matched by the requisite amount of national saving. It is possible for foreign capital inflows to finance domestic investment, even for long periods of time, so long as the returns on the domestic investment generate the requisite income to pay the foreign capital exporter, i.e. the marginal productivity of domestic capital exceeds the marginal cost of foreign borrowing. Differences between countries in national saving and investment rates will reflect different aptitudes, opportunities and preferences for consumption and production over time. If there were no major distortions (such as capital controls or tax distortions) and markets functioned well, there would hardly be a problem if national saving and investment did not match. But, as later sections will discuss, there are important distortions influencing the decision to save or consume, as well as to invest in real assets at home or abroad. Such distortions may well mean that national saving and investment rates are sub-optimal and any gaps between them may be reflecting disequilibria.

The neo-classical closed-economy model, where the "steady-state" growth rate is determined by the growth of the labour force and improvements in technology, provides some insights to understanding investment, saving and growth in the $1950 \mathrm{~s}$ and $1960 \mathrm{~s}$ (2). In that period there were ample investment opportunities to undertake post-war reconstruction and achieve technological "catch-up" with the United States (see Maddison, 1987). In this context, as argued by Boskin (1988), the much lower saving and growth rates of the United states relative to other countries were not unreasonable. However, as population growth, slowed and the potential for catch-up was gradually exhausted, there was also a gradual lowering of investment and saving rates in other countries in the 1970 s and 1980s. A slowing in the growth of potential output which reflected slower labour force growth or slowing in technological progress would entail a lowering in the investment rate.

The rate of investment would seem on some evidence to play a much more active role in growth processes, however. Investment and the process of technological change are often inextricably related. New production processes are normally embodied in new capital, and reorganisation of the firm's workforce and method of operation often accompany large investment expenditures (3). In a recent OECD study, Englander and Mittelstädt (1988) suggest that there has been a marked decline in the pace of productive capital accumulation since the early $1960 \mathrm{~s}$ in most OECD countries, and they identify 
lower growth of productive capital as one of the most important explanations of the slowdown in total factor productivity growth. A study by wolff (1987) found a strong positive correlation between the rate of technical progress (as indicated by total factor productivity growth) and the rate of growth of the capital stock, which he interpreted as confirmation of the embodiment hypothesis. There may be good reasons, therefore, why low investment is frequently linked with poor economic performance. Thus saving and investment would seem to be instrumental in the growth process and not simply passive reflections of exogenous processes of innovation.

Investment trends. There are various ways of looking at trends in investment but most of the measures seem to indicate that investment rates in OECD countries have generally been lower during the $1980 \mathrm{~s}$ than in the $1960 \mathrm{~s}$ and $1970 \mathrm{~s}$ (see Table Al in Annex I). It is nevertheless important to note that conventional measures of investment do not include expenditures on research and development and investment in human capital leducation and training) which may crucially affect the quality and productivity of the capital stock (4).

With the OECD area entering its seventh year of recovery, it is encouraging that in most OECD countries total gross real investment rates have increased in recent years or are projected to increase substantially over 1989-90 (Chart B). The resurgence in investment is linked to the strong rise in rates of return since the last recession and generally high levels of capacity utilisation in most OECD countries (5). Rates of return have recovered sharply in all the major countries with the exception of Japan. In the United States they are as high as before the first oil shock, in Canada even higher. Meanwhile rates of capacity utilisation have increased rapidly and suggest the need for continued high investment if demand growth is to be maintained.

In most OECD countries, business investment has held up better than overall investment as both housing and government investment rates have declined over most of the period since 1960 (see Chart B and Table Al for details). Declines in housing investment have usually been associated with demographic factors in the long run and monetary restraint in the short run, though a more recent pick-up in some countries is linked to financial market liberalisation and monetary easing until recently. The reduction in government investment is related to pressures on public expenditure more generally.

\section{ii) The international dimension}

In a world of integrated financial markets, saving should flow across national borders to seek the highest expected risk-adjusted, after-tax rate of return, Capital flows tend to equalise the demand for and supply of loanable funds and establish a common global real rate of return (adjusted for tax and risk). Hence, an exante increase in saving in one country could increase investment everywhere. On the other hand, if restrictions on capital movements existed, national investment would be constrained to some extent by national saving and rates of return to capital would differ. For many years, the latter situation seemed to prevail and there was a strong covariation of saving and investment within countries. More recently, as financial markets have become more and more globally integrated, this relationship seems to have been waning. 
During the $1960 s$ and 1970 s there was a broad balance between national saving and investment within OECD countries except for a few countries which remained habitual capital exporters (Switzerland and the Netherlands) or importers (Canada, Greece, Ireland and some Nordic countries). Even when, as in the early 1970s, there was an oil price shock that effectively reduced the net saving of the industrialised countries and raised optc saving, saving/ investment gaps were eradicated relatively quickly, at least in most industrialised countries -- the developing countries borrowed more, sowing the first seeds of the debt crisis. But while the imbalances were soon eroded, the levels of national saving and investment were in general lower from the mid-1970s onwards.

Not only have national saving rates in the $1980 \mathrm{~s}$ been lower than in the $1960 \mathrm{~s}$ and 1970s, but gaps have persisted in a few countries where investment and saving, taking several years together, had previously been relatively well-balanced. The emergence of such gaps, which has been reflected in persisting current-account imbalances, has coincided with a period of greater international financial market liberalisation and persistent exchange-rate misalignment.

While capital flows have permitted saving/investment gaps to develop and persist, the fundamental causes have been associated with the underlying behaviour of national saving and investment and exchange-rate developments related to differences in policy mix. In Japan, Germany and the Netherlands, where there has been an excess of national saving over investment, the excess has occurred because investment has declined by more than saving. In contrast, in the United States, the United Kingdom, Canada and Australia, where national saving has been inadequate to finance investment, the cause has been a substantial fall in saving. In the United states, gross total investment as a share of GNP has been relatively well maintained in the 1980 , after a strong recovery following the sharp drop during the recession, while in Canada and Australia investment has declined but by far less than saving.

In a study covering the period of broad balance between national saving and investment, Feldstein and Horioka (1980) tested the degree of capital mobility between countries by regressing domestic saving on domestic investment ratios using cross-country data and average ratios over runs of several years. Results for the years 1960 to 1974, both for the entire period and for sub-periods, showed that domestic saving passed into domestic investment nearly one to one. A more explicit structural model which allowed for inter-country differences in saving behaviour (e.g. differences in pension benefit/earnings replacement ratios or the age structure of the population) yielded the same results. These findings suggested that an increase in saving in one country added little to an internationally-mobile pool of saving and investment. The result was generally confirmed by later studies, as indicated in Annex II.

Nevertheless, the Feldstein-Horioka result gradually came to seem less relevant in the $1980 \mathrm{~s}$ as freer movement of capital and the development of imbalances seemed to contradict the basic thesis. Some new research showed different results (Obstfeld (1985), Turner (1986)). A repetition of Feldstein and Horioka's work -- regressing five-year averages of saving on investment ratios - and extending the sample to 23 OECD countries and the time period to 1987, suggests a less important correlation of national saving and investment 
than previously. While the coefficients in the regressions for the $1960 \mathrm{~s}$ and early 1970 s are close to one, they drift down later to reach a low of only 0.58 for the last five-year period from 1983 to 1987 (Table 2). Foreign financing seems to have become more important and it has apparently become much "easier" to sustain saving/investment imbalances over longer periods (6). The rapid increase in international financial interdependence is also evident from the growth in foreign assets and liabilities (Chart $C$ ).

The extent to which capital flows in recent years have conformed to the idealised model is a contentious issue. Moreover, as Williamson (1985) has pointed out, it is difficult to establish what the time preferences and marginal efficiencies of investment are which would allow one to judge whether welfare-maximising capital flows are taking place. Welfare maximisation in the context of liberalised capital markets would require equalisation of before-tax rates of return (7). However, considerable differences in effective marginal rates of income taxation exist, which distort decisions on where to locate physical and financial investment.

\section{GOVERMMGNT SAVIKG AND DISSAVING}

The main change in the sectoral composition of national saving between the $1960 \mathrm{~s}$ and $1980 \mathrm{~s}$ in most countries is the reduction in general government saving (Table 3). In every case apart from Norway, there was a reduction in government saving and in half of the cases shown in the table the government moved from being a saver to a dissaver.

During the $1960 \mathrm{~s}$ government saving contributed to aggregate saving in all the OECD countries shown in Table 3 . In some cases the contribution was substantial. In Japan, Germany, Austria, Finland and Norway gross government saving was more than 5 per cent of gross national product or close to a quarter of gross national saving. In most countries government saving could cover capital outlays and for the area as whole the financial position of governments was roughly in balance.

During the $1970 \mathrm{~s}$ government saving fell more than capital outlays and financial deficits became large in some cases. After the first oil price shock, revenue growth slowed because of the slowdown in activity, while expenditure growth continued to outstrip GDP growth due to the spending momentum built into.social programes put in place in a period of high growth expectations. In many cases discretionary policies also aimed at cushioning the adverse demand effects of the first oil-price shock. The build-up of government debt and rising interest rates at the turn of the $1980 \mathrm{~s}$ boosted expenditure further. Increased interest payments only partly compensated holders of government debt for the inflationary erosion of asset values, so that inflation-adjusted government saving was much higher, especially in countries with high inflation and a large amount of outstanding debt such as Italy and Belgium.

During the period 1981-87, government saving fell again and public sector borrowing to finance government consumption and transfers on a large scale became widespread. Among the major seven economies, only the Japanese, 
German and French governments covered current expenditure with current revenue. Dissaving as a per cent of GNP reached 2.4 per cent in the United States, 2.2 per cent in Canada, 6.0 per cent in Italy and 6.6 per cent in Belgium (Table 3). In some cases dissaving persists even though the understatement of government saving arising from inflation was markedly reduced as inflation came down.

In many countries reduced gross government saving more than accounts for the fall in gross national saving between the 1960 s and $1980 s$. In the United States, for instance, the gross national saving rate fell by 3.3 percentage points, that of government alone by 4.2 percentage points, with the private sector saving rate being about 1 point higher (Table 3 ). Other countries where the government saving rate has fallen by more than the national saving rate are the United Kingdom, Italy, Canada, Austria, Belgium and Finland. In Japan and Germany the fall in the national saving rate has been due to a combination of declines in the government and the private sector rates. Of the ten countries covered in Table 3, Norway is the only one where the government saving rate has picked up between the $1960 \mathrm{~s}$ and $1980 \mathrm{~s}$, presumably because of oil revenues, but this has been partly offset by a fall in the private sector saving rate.

The implications of persistently large government deficits and rapidly growing debt led governments to seek to correct financial balances. Significant consolidation results were achieved in Japan, Germany, Denmark, Ireland, Sweden, Australia and New zealand. Government debt/GNP ratios began to fall in a number of countries as from the mid-1980s (8). Other countries made much less progress and in some countries -- the United States, Canada and Italy among the major seven economies -- government dissaving was still significant by 1988, even though lower than at the cyclical peak in the early 1980 s (Chart D). Table 4, which shows government net lending as a per cent of private gross saving also illustrates increasing government claims on private funds in most countries since the 1970 s and consolidation efforts during the 1980 s.

The effects of government deficits on private saving are manifold and interact importantly with policy measures which may be fiscally neutral on the budget but affect the intertemporal choice of individuals. One view, known as the "debt neutrality hypothesis" or "Ricardian equivalence" argues that individuals "pierce the government veil" (9). The private sector is assumed to-anticipate the future tax burden associated with government debt service and adjust its saving accordingly. On this view, the way public outlays are financed does not affect the flow of funds available for investment nor interest rates and makes the choice between tax and debt finance irrelevant to macroeconomic outcomes. "Crowding out" of investment or consumption would only occur by the direct absorption of government goods and services.

A recent OECD study by Nicoletti (10), which also provides a summary of earlier work on this topic, found little empirical support for the strict "debt neutrality hypothesis". For most countries the estimated offset of an increase of government deficits by an increase in private saving was much lower than one for one, but still significantly different from zero in the cases of the United States and Canada. Italy and Belgium, two countries where high debt/GNP ratios have threatened explosive debt dynamics, were exceptions in exhibiting something approximating debt-neutrality behaviour, suggesting 
that there may be some sort of threshold effect. Ireland, though not in the study, might also be included in this category.

The rejection of the strict debt neutrality hypothesis in empirical work does not mean that fiscal action has little influence on private saving since partial offsetting is still likely. Furthermore, as reviewed in section III, tax distortions are important and changes in tax rules, even if they are deficit-neutral, can have a strong impact on private saving. In addition, expenditure programmes can change saving patterns. The introduction of a pay-as-you-go system for financing pensions or extension of health care and public education programes would be likely to reduce private saving previously committed to meeting future pension, health and education requirements.

\section{PRIVATE SECTOR SAVIMG}

\section{A. Overall trends}

Private sector saving is by far the largest source of financing for national investment. Even though, as noted above, the contribution of government to national saving has been significant at certain times (notably the 1960s) and in certain countries (Japan, Norway and Switzerland), in general it is the private sector that has been the main provider of investment finance. Some of this saving has been intermediated, originating in the household sector, but much of it has been from internally-generated funds of business. In addition, as noted above, the foreign sector has become increasingly important in closing national saving/investment gaps.

Developments in private sector gross and net saving rates are summarised in Table 5. Private sector gross saving rates have been fairly stable over time. Apart from fairly sharp increases in Canada and the United Kingdom, gross private saving rates in the first half of the 1980 s were little different from their levels in the 1960s. Differences across countries are also relatively small: in the first half of the 1980s gross private saving rates were in the range of 16 to 23 per cent apart from Japan where the rate was 27 per cent. These trends may have been influenced by the gradual increase in wealth in most countries. In general, private wealth/GNP rates are now significantly higher than in the early 1970s (Chart $E$ ).

Gross private saving rates generally have been less volatile in the past than either their component household and business rates or the national saving rates (Table 6). Households are the ultimate owners of businesses, so that they may view retained business earnings as a close substitute for their own saving. More concretely, in periods of strong corporate sector profit expectations, market valuation rises; since this will raise household wealth and probably influence consumption, some offsetting of business and household saving is likely. Earlier studies of the United States found evidence that changes in household saving were nearly completely offset by changes in business saving. Denison (1958) and David and Scadding (1974) found greater stability in private sector saving behaviour than in either personal or corporate saving. More recent studies such as Poterba (1987), Kotlikoff 
(1988) and schultze (1988) have indicated a less than complete offset. Poterba estimated that a fall in U.S. corporate saving of $\$ 1$ increases household saving by roughly 50 to 75 cents and schultze estimated a change of 55 cents. The situation might be rather different for small open economies where domestic firms' assets are not all held by domestic households while the latter possess a lot of foreign assets, cf. the case of Belgium.

Despite the record of stability of private saving ratios, just recently such ratios have dropped considerably in a number of countries. The downward movement has been especially sharp in Denmark, Sweden and Norway but still appreciable in the United States, the United Kingdom and Italy (Chart D). In the short term, lower private saving can be expected to lead to higher expenditure and, through higher tax revenues, to greater government saving, i.e. the reverse causality to the Ricardian equivalence discussed above.

\section{B. Business saving}

Business saving accounts for a considerable part of funds to finance investment. Including depreciation, business saving provides about half of private saving in most countries. Gross and net corporate saving and investment, ratios are shown in Table Al.

Developments in business saving track profit developments very closely, differing from profits by the amount of dividends paid out to shareholders. While profits were rather stable in North America during the 1960 s and early 1970s, a considerable squeeze occurred in most European countries and Japan. Profit shares and rates of return reached low levels between the mid-1970s and early $1980 \mathrm{~s}$ but have rebounded sharply since then. Ratios of corporate saving to GNP closely mirxor these developments (Table 7 and Table Al).

During the profits squeeze of the 1970 s business investment was sustained by considerable borrowing. The ratio of corporate interest payments to GDP increased considerably and continued rising into the 1980s. This reduced cash-flow further in the early 1980s. Interest payments of corporations as a proportion of GDP had, for instance, trebled since the $1960 s$ in the United states and doubled in Finland. In addition to the low capacity utilisation rates reached in the early 1980s, a desire to restructure balance sheets may help to explain the slow recovery of business investment in many countries during the initial phase of the current upswing. But a sharp recovery in profits in recent years, associated with wage moderation, has played a vital role in increasing business saving to levels closer to those of the 1960s. These developments have contributed to: 1) stronger corporate cash-flow, and 2) reduced interest payments following balance-sheet restructuring.

\section{Household saving}

\section{i) The rise and fall of household saving}

Gross household saving ratios increased substantially in the 1970 s and then decreased markedly in almost all OECD countries during the course of the $1980 \mathrm{~s}$ (11) (Chart F). The uncertain economic environment of the two oil price 
shocks and the inflation of the 1970 s seem to have contributed to the rise in saving ratios while the disinflation and sustained recovery of the $1980 \mathrm{~s}$ seem to have contributed to their fall. The decline in household saving ratios in recent years has been particularly pronounced in some countries, often associated with financial market liberalisation.

Household saving ratios are now lower than in the $1960 \mathrm{~s}$ in the Scandinavian countries, in a few other European countries (the United kingdom and France) and in the United States and Australia. They also followed a downward trend in Japan, Italy and Ireland in the $1980 \mathrm{~s}$ but remain higher than in the 1960 s and relatively high compared with the OECD average (Chart F).

Because capital depreciation is difficult to evaluate, both within and across countries (12), especially in periods of inflation, net saving ratios tend to be less reliable than gross ratios. Nevertheless, the pattern of trends in net household saving ratios is similar to that for the gross ratios (Chart F). In Finland, Norway and Sweden recent declines have even led to negative household net saving ratios. Current trends and prospects for most OECD countries up to 1990 do not point to a reversal of the downward trend, but rather to a stabilisation of net household saving ratios around current levels (see Chart D).

\section{ii) Is household saving being measured "correctly"?}

A number of measurement problems, besides those of measuring depreciation, may distort calculations of household income, consumption and saving in the national income accounts (Blades, 1983; Boskin, 1988). Annex III reviews a number of these issues and identifies different kinds of possible adjustments that would be necessary to derive measures of household saving ratios which would be more consistent across countries. Apart from the exclusion of unincorporated enterprises from the household sector, these adjustments concern the inclusion of purchases of consumer durables in capital rather than current expenditure, the standardization of the treatment of public and private pension and life insurance schemes and the inclusion of saving by social security funds. It should be noted that these adjustments either have a counterpart in the definition of saving of other sectors (adjustment for pensions and social security, exclusion of unincorporated enterprises) or in the definition of household investment (adjustment for consumer durables), and do not as a matter of definition affect the overall national investment/saving balance. Such adjustments do not in practice have much effect on the inter-country disparity in saving ratios. They affect the levels of the household gross saving ratio, sometimes substantially, le.g. the exclusion of consumer durables from consumption expenditure in the case of the United states or the inclusion of pension fund saving in sweden), but in general do not have a marked impact on the trends.

Measured trends in household saving ratios are significantly altered, however, if an adjustment is made for holding gains and losses arising from inflation. Because disinflation has been an important phenomenon in the 1980s, it has been argued that part of the decline in household saving ratios could be attributable to the mismeasurement of inflation-induced changes in household income and saving. Although measured nominal income and outlays include interest receipts and payments which include inflation premia, holding gains and losses on financial assets and liabilities do not enter into the 
calculation of income or saving in the standardized National Accounts. However, when there is persistent inflation, holding losses and gains on monetary assets and liabilities which tend to be recurrent and predictable should also be treated as current transactions (Hill, 1984 and 1988). Nominal interest payments should therefore be corrected by offsetting imputed transfers between creditors and debtors to avoid overstating the saving of the creditors and understating the saving of the debtors. Inflation adjustment reduces the level of saving of the lending sectors and increases that of the borrowing sectors. The mirror image of the inflation adjustment of household saving can thus be found in the business and government sectors, at least for countries with a net external: position close to zero.

Chart $G$ shows inflation-adjusted saving ratios for the major seven countries in the 1970s, a period of increasing inflation, and in the 1980s, when the deceleration of inflation was pronounced (13). The major feature is that the inflation adjustment substantially mitigates movements in unadjusted rates and in some cases reverses the trends. In the United states, for example, the gross saving ratio on an inflation-adjusted basis, would have increased by about 4 points between 1980 and 1986 , compared with a decline of $31 / 2$ points on an unadjusted basis. In Germany and Italy, where SNA.gross saving ratios remained broadly stable in the $1980 \mathrm{~s}$, the adjusted ratios show a marked increase (see also Table A3). In general inflation adjustment changes the story about when household saving rates rose and fell but does not change the position of saving ratios in the $1980 \mathrm{~s}$ relative to the $1960 \mathrm{~s}$.

Measurement problems due to exchange-rate movements are of the same nature as those arising from inflation and should in principle be taken into account, to the extent that a proportion of financial assets and liabilities held by households is denominated in foreign currency. A study covering Canada (Haydu, 1987) show that the household saving ratio adjusted for changes in real exchange rates would have been somewhat lower since 1976 because of the depreciation of the Canadian dollar vis-a-vis the U.S. dollar. This suggests that variations in exchange rates could have had some impact on the measured household saving ratios in other countries during the period of exchange-rate volatility in the 1980s, though no adjustments have been attempted here.

\section{iii) Why do households save and can inter-country differences be explained?}

There is a large body of theoretical as well as empirical work on the determinants of household saving behaviour. For individual households the main saving motives are: to allocate consumption over time given a pattern of expected income flows (14) and particularly the necessity to save for retirement, as embodied in the life-cycle hypothesis (15); to allow for uncertainty about the future, which leads to a demand for precautionary assets; and the willingness to save for bequest. In the short to medium term, saving and dissaving by households also occur because of the planning of future acquisition of consumer durables and housing. household saving behaviour thus depends on demographic factors, current and expected wealth, and institutional or structural characteristics, such as financial market opportunities, pension schemes and tax systems, which interact with individual household saving behaviour to determine aggregate saving ratios (16). variations in a number of these factors explain some of the differences in 
saving ratios across countries or within a country over time. Those most relevant for a comparative analysis of the household saving behaviour in the $1980 \mathrm{~s}$ are briefly discussed below. The important influence of changes in net worth and debt is addressed separately in Section $v i$ ).

Demographic factors -- that is, changes in the age distribution of the population -- alter the aggregate household preferences if, as suggested by the life-cycle hypothesis, an individual's propensity to save varies with age (Musgrove, 1982; Barnes and Gillingham, 1984; Modigliani, 1986; Graham, 1987). A recent analysis by Heller (1988) of the effects of demographic changes on saving rates in the major seven OECD countries shows that the share of elderly in the population has reduced saving (and could continue to reduce it substantially into the first quarter of the next century) with the largest declines expected to occur in Japan. As shown in Table 8, the old-age dependency ratio has indeed increased in most countries in the $1980 \mathrm{~s}$ compared with the $1970 \mathrm{~s}$ and the 1960s. Horioka (1986) also estimates that important forthcoming changes in the age structure of the population in Japan could lead to a precipitous decline in the household saving ratio after 1995 . The ageing of the population could have a similar effect in Germany and in some other countries (17). There is thus some economic rationale for Germany and Japan currently having relatively high private and national saving ratios, with savers seeking the highest real after-tax rate of return internationally.

Not only does the age structure of the population change, but there is evidence that individuals of a given age behave differently than earlier -- a "vintage effect". Based on a decomposition of the U.S. population by cohorts, Boskin and Lau (1978) estimate that persons born since 1939 have, at the same age, a significantly lower propensity to save than those born prior to 1939. Similarly, Kessler (1989) estimates that, in 1988, French households aged between 25 and 45 have a higher propensity to consume than their parents had at the same age and, as noted by Christine (1989), this effect may have been enhanced by the liberalisation of financial markets. Other social factors such as youth dependency ratios and labour force participation of the aged and of women (18) may also help to explain differences in household saving ratios across countries. Table 8 presents a synthetic indicator of the demographic and social influences on household saving ratios for the major seven countries over the 1980 s which shows that, based on a simple composite ranking of these factors alone, the levels of saving rates should be comparatively high in Japan and Italy and low in the United States and the United Kingdom.

The increase in the share of the elderly in the population has been accompanied by an improvement in their economic situation, and this has also been advanced as an explanation of reduced aggregate saving. The way in which compulsory social-security systems alter the time pattern of consumption, and hence saving, has been discussed by a number of authors. Feldstein and Pellochio (1978), for instance, found that social security significantly depressed private wealth accumulation in the United States in the 1960s, and Boskin, Kotlikoff and Knetter (1985) and Sumners and Carroll (1987) argued that the increase in the relative well-being of the elderly is an important cause of the drop in the U.S. household saving ratio in the 1980s. Although some doubt has, been cast on such an effect by a number of other authors (Barro, 1978, Leimer and Lesnoy, 1982, Kaskela and Viren, 1983, Auerbach and Kotlikoff, 1983) empirical evidence of the depressing effect of social security on saving has been found more recently in a number of other 
countries. Bentzel and Berg (1983) argued that the introduction of the public social security systems in sweden had a significant depressing impact on private saving (which would mitigate the pensions adjustment mentioned in Section ii). Similarly, Shibuya (1987) and Brugiavini (1987) found empirical evidence of reduced saving due to public pension schemes in Japan and Italy respectively. Annex III reports gross household saving ratios adjusted for this effect. It should be stressed that public pension expenditure rose substantially in most OECD countries in the 1980s, representing an average of 9 per cent of GDP for the major seven countries compared with 7 per cent in the 1970s. This evolution has been even more pronounced in some of the smaller economies, the most striking example being sweden, where public pension expenditure represented 5 per cent of GDP at the end of the $1960 \mathrm{~s}$ and almost 11 per cent in 1985 (19).

How interest rates affect saving is an important issue as it bears on questions regarding public indebtedness and the effects of fiscal policy. The liberalisation of financial markets which has occurred during the $1980 \mathrm{~s}$ has made this issue more relevant, as it has increased the role of interest-rate movements in balancing demand and supply in financial matters. A priori, the effect of interest rates on saving is ambiguous, since they have both an income (via net interest payments) and a substitution effect. Hall (1985), for instance, found strong evidence that a higher expected real interest rate makes U.S. consumers defer consumption and Boskin (1978) pointed to a "modest positive interest elasticity of U.S. private saving". Dicks (1988) also emphasized the positive interest elasticity of saving in explaining U.K. household saving behaviour. This conclusion was confirmed for seven other industrial countries by Tullio and Contesso (1986) (20). Beach et al. (1986) found that in Canada the age distribution of the population was important, the response of aggregate household saving to changes in real'rates of return being positive for the young (the substitution effect dominating) and negative for those approaching retirement (income effects dominating). The effect of interest rates operating through wealth effects, as described below, is also likely to be important.

\section{iv) Unanticipated inflation and uncertainty}

Changes in inflation may lead to real changes in saving as well as distorted measures of it because, at least in the short term, nominal interest rates may not adjust to fully offset inflation. In response to such unanticipated inflation, individuals may save more in order to maintain their real wealth positions. similarly, periods of decelerating inflation which result in an unexpected better real wealth position, could induce individuals to save less (Jump, 1980). This behavioural link between saving and inflation is different from the pure measurement problem discussed above which in any case also occurs when interest rates increase in line with inflation, i.e. when inflation is anticipated. Recent econometric studies suggest that inflation-induced wealth effects have had a positive impact on saving in most OECD countries (21).

Apart from the induced wealth effects, the relation between saving and inflation is also a reflection of uncertainty. As periods of high inflation are often periods of more general uncertainty, households may react by adding to their stock of precautionary assets. During the two oil price shocks in the 1970s, when inflation surged, inflation-adjusted household saving ratios 
increased strongly in Japan and more moderately in Canada. In Japan, France and Canada inflation-adjusted saving ratios declined markedly in 1974 before rising sharply again in 1975 (Chart G). On the other hand, during the $1980 s$ the long period of disinflation may have contributed to some reduction in uncertainty, thereby inducing some running-down in precautionary assets.

\section{v) Eunctional income distribution}

If households have a higher propensity to save out of property income than out of labour and transfer income, as suggested by Taylor (1971), then household saving may typically be higher in countries where a high proportion of profits is distributed. The share of property income out of total income over the last two decades is shown in Table 9. The liberalisation of financial markets as well as the disinflation process of the 1980 seem to have contributed to a functional redistribution of household disposable income. There appears to have been some relation between developments in property income and household saving in some countries, for example the United Kingdom, Austria and the Netherlands. The Secretariat has also found evidence of this in its consumption function for Denmark. For most countries, however, saving ratios have decreased even though property income has risen. This may be explained by the large improvements in household net worth in the $1980 \mathrm{~s}$ examined below, which may have induced lower household saving ratios in a number of countries.

\section{vi) The broader picture; personal net worth and debt}

Net worth. The life cycle and permanent income approaches to consumption stress the importance of net wealth positions in affecting consumption/saving behaviour. In the life-cycle approach, households have some target wealth position (changing systematically over the life cycle) to support consumption through their lifetimes while, in the permanent income approach, permanent consumption is defined as the amount that can be consumed that leaves net wealth unchanged (including the discounted present value of expected labour incomel. In either case, from the household's point of view, improvements in net worth give rise to a lower need to save. Despite low saving in many countries, data depicting net worth or net financial wealth suggest a broadly healthy or strongly improving financial picture for the personal and total private sectors in recent years, even allowing for the October 1987 stockmarket decline (Charts E and H) (22).

During the 1980 s personal saving ratios have fallen while the ratio of personal net worth (or net financial wealth for Italy) to personal disposable income has risen significantly in the United States, Japan, the United Kingdom and Italy. In Germany, changes in net financial wealth/income closely follow the saving ratio because shareholdings are small. In Canada there is no clear link between saving and net worth/income ratios over most of the past 25 years (23).

Equities. Housing (including land) and equities generally account for much of the variation in household wealth. Until the October 1987 stockmarket decline, capital gains on equity were boosting wealth relative to household disposable income, encouraging a reduction in household saving. The loss in wealth after the October decline was expected to lead to slower growth of consumer spending and increase the saving ratio -- and more so in those 
countries such as the United states where losses on equities were a more important component of changes in household net worth -- but in most countries consumption growth hardly slowed or slowed by less than expected.

Several factors appear to be important in explaining the continued buoyancy in consumer spending after the October 1987 decline. In hindsight a large part of the build up in equity prices may have been regarded by many equity holders as temporary. In most countries the october decline merely wiped out most of the year's gains and in many countries equity prices have subsequently recovered substantially; in Japan they have passed the pre-crash peak. The recovery in equity prices and the strength of consumer spending after the october decline suggest that the underlying strength of oECD economies was under-estimated at the time, but can also be associated with the prompt availability of ample credit as central banks acted to avoid a financial crisis.

Housing. In Japan and the United Kingdom changes in the value of the housing and land stock have dominated changes in net worth over the past 20-25 years and in most years have been larger than the aggregate value of personal saving. Increases in the value of the housing stock have also been large in Canada, Australia, Sweden and Norway in recent years. In most of these countries the greater availability of credit through financial liberalisation, or general monetary ease as in the case of Japan, has been an important factor in explaining the rapid growth of mortgages and property prices.

Capital gains on housing often increase net worth substantially and hence stimulate consumption. In the United Kingdom there is evidence that the rapid growth of house prices in London has encouraged equity withdrawals as property is bought and sold with a substantial part of sales proceeds being consumed and not reinvested (24). In several other countries, financial liberalisation and competition have also made it easier to use home equity as collateral for other loans. In addition, the tax system often favours investment and saving in the form of housing, and this effect has become more important as other distortions have been removed and credit has become more available (see Sections vii) and viii)).

Personal debt. Increases in personal net worth have been accompanied by a rapid build up of gross personal debt in recent years, particularly in the United States, France, the United Kingdom, Australia, Sweden, Finland and Norway. The increase of personal debt can be closely related to an easing of borrowing constraints associated with significant financial market liberalisation and innovation. In the case of France, for instance, some credit liberalisation occurred in 1986 and the removal of credit controls for households at the beginning of 1987 has encouraged consumption and borrowing (25). But the most important.increases in debt have been directly related to housing or to consumer loans based on housing equity.

Borrowing for housing represents the largest liability of most households in most OECD countries. In some countries credit rationing of housing finance, which was previously extensive, has largely disappeared. rormal and informal saving and downpayment requirements have been substantially reduced through liberalisation and competition in financial markets. In the United States the average down-payment as a per cent of the 
sales price fell from 20.5 to 11.4 from 1980 to 1985 (26). In the United Kingdom over half of those buying their first property in 1987 were given mortgages of 95 per cent or more of the purchase price (27). Similar developments have accompanied financial liberalisation in Australia, Sweden, Finland and Norway in recent years. Furthermore in many of these countries consumer loans based on the value of housing equity have become significant. In the United States home-equity financed credit has grown rapidly as a result of the Tax Reform Act of 1986, although there is evidence that it has largely substituted for other consumer debt with little effect on aggregate borrowing (28). In the United kingdom and some of the Nordic countries, however, such Ioans seem to have contributed to the sharp rise in personal debt in recent years.

In linking the build-up in household borrowing for mortgages to the drop in the household saving ratio it is helpful to consider how the relevant transactions are treated in the national accounts. The saving ratio for a typical household falls considerably after the purchase of a house but then rises again as interest payments (a deduction from income) become less important relative to principal repayments (saving) (29). There would be no effect on the aggregate household saving ratio if the dissaving of some households were offset by the saving of others. However, in most OECD countries the "baby-boom" demographic bulge has in recent years led to an increase in the size of the age groups characterised by high rates of family formation and associated expenditure on housing and its accoutrements, thus providing a large base for the growth of debt through financial liberalisation to have an important effect. In the United States, for example, there has been a rapid increase in the rate of household formation in recent years and this has been accompanied by a surge in housing investment (30).

\section{vii) Tax structures and their influence on household saving}

The potentially undesirable way in which tax structures operate adversely on the level and form of saving and investment is of increasing concern. Because after-tax rates of return tend to be lower than before-tax rates under an income tax, saving may be discouraged by discriminating against future relative to current consumption, though heavy reliance on consumption taxation may have the reverse effect. Whether such a distortion is, in fact, important depends on the size of the tax wedge (the difference between before and after-tax rates of return) and the elasticity of saving with respect to the after-tax rate of return. Because, for a net saver, the income and substitution effects are of opposing signs, the net effect of income taxation on saving is ambiguous. As noted earlier, recent studies suggest that saving is likely to be more positively responsive to the after-tax rate of return than previously thought.

A large number of different tax instruments influence saving. No current tax system tries to treat all forms of income in an equal manner, and no existing tax system provides a total exemption of saving and capital income from taxation as would be the case in a tax system with a pure expenditure tax. Research has increasingly indicated that current tax systems are in many cases likely to have a discouraging impact on saving, and that moves away from taxation of saving and capital income could provide substantial economic gains. Eor instance, simulations of dynamic general equilibrium models, such as those of Auerbach and Kotlikoff (1987), show that a shift away from capital 
taxation towards taxation of labour income, or a move towards a consumption tax, could increase capital formation and output substantially in the long-run (31). In the former case, greater neutrality with respect to saving would come at the expense of a larger distortion of incentives to accept employment.

Saving incentives. Many countries provide fàvourable treatment of some form of financial saving, especially that related to retirement pensions. A critical question arises as to whether such tax incentives increase aggregate household saving, or whether they only result in a transfer of saving into a preferentially-treated category. Carroll and summers (1987) found strong evidence that the sharp divergence in Canadian and U.S. saving rates since the end of the $1960 \mathrm{~s}$ can partly be explained by the generous tax treatment of pension contributions in Canada, and Venti and Wise (1987) found some evidence that introduction of IRAs in the United states increased financial saving of households somewhat. Fox Japan, Shibuya (1987) found a small positive effect of generous tax exemption provisions for interest income on household saving.

Investment in owner-occupied housing receives a considerable amount of preferential tax treatment (32). This preferential treatment arises via several channels such as tax relief on mortgage interest payments and exclusion of capital gains and non-taxation of implicit rental income (Table 10). Among OECD countries, only Canada, New Zealand and Turkey allow no tax deductions or credits for mortgage interest payments. While tax relief is limited in a number of countries, many provide for full deductibility of interest, and in some countries this extends to secondary residences as well. In terms of economic efficiency, tax deductibility of interest payments would be justified with respect to investment in housing if the accrued income on housing investment (including capital gains and implicit rental income) were taxed. However, capital gains and imputed income, if taxed at all, are only lightly taxed in most countries. Estimates of tax wedges for investment in owner-occupied housing for some OECD countries are shown in Table 11 (using tax parameters for 1985). Tax wedges (differences in pre- and after-tax rates of return in percentage points) are large for countries which allow generous or complete deductibility of interest payments. In this case, the tax wedge increases considerably with inflation (e.g. in Sweden, the united Kingdom and the United states). The extent to which the favourable tax treatment really benefits first-time buyers is not clear since such measures increase demand, with the result that the tax incentive may be capitalised in existing house and land prices. To the extent that tax breaks then lead to "overinvestment" in housing, the funds available for business investment are reduced.

Disincentives to saving. Deductibility of consumer credit interest payments clearly favours debt-financed consumption although this may be offset by heavy taxation of consumption. Such deductibility is provided in only a few OECD countries (Table 12). However, where, as is sometimes the case, mortgage credit is not tied to actual construction activity or in practice can be used for other purposes, the bias against financial saving is exacerbated. If no restrictions apply, possibilities for arbitrage arise where consumer or mortgage credit can be used to buy tax-sheltered financial assets, so that lower tax payments finance part of the asset purchase. Generosity of tax systems with respect to consumer goods purchases are but one feature influencing household saving. Nevertheless, countries with low household 
saving ratios, like the United States and the Nordic countries, are among the most generous in this respect.

\section{viii) The interaction of financial market liberalisation and tax distortions}

Tax deductibility of interest payments is not generally a new feature of tax systems. But financial market liberalisation has eliminated or reduced credit rationing so that households have been able to take greater advantage of tax incentives related to purchases of housing or consumer goods by borrowing at an earlier stage of their lifetimes and making larger purchases than would otherwise be the case. The attractiveness of borrowing for housing and consumer goods has been further enhanced as other distortions have been removed in the personal income tax system in some of these countries. The net effect on housing may have been to encourage overinvestment. Although the initial effect of recent financial market liberalisation has apparently been largely reflected in rising values of existing properties, the volume of housing investment grew by 15 per cent or more in 1988 in the United Kingdom, Australia and Finland, three countries where these interactions are clearest. The increase in household borrowing and decline in the household saving ratio have in turn been reflected in a deteriorating external position. Thus financial liberalisation has worsened the effects of remaining distortions and have led to imbalances elsewhere in the economic system. This should not, however, be offered as an argument to re-introduce controls and regulations, but rather as an example of why it is important to continue to proceed with reforms on a broad front and in a co-ordinated way.

\section{IV. concrosions}

The long-run trend in the levels of saving and investment

The paper has identified a reduction in national saving and investment rates in most OECD countries over the last two decades. Some reduction might have been expected given the slowing of population growth and as post-war reconstruction in certain countries was completed. The possibility of strong productivity growth arising from technological "catch up" has been reduced. Moreover, the oil price shocks in the $1970 \mathrm{~s}$ and the disinflation and generally high level of real interest rates in the 1980s, have clearly impaired both growth and investment. Nevertheless, insofar as embodiment of technical progress is important, there may have been a link between the general reduction of national investment rates and the lower rates of growth generally experienced over this period. A more recent concern, that might argue for investment having been inadequate in recent years, is the strong increases in rates of capacity utilisation in nearly all countries and associated inflationary pressures.

\section{National saving/investment gaps}

National saving/investment gaps -- current-account deficits -- are sustainable only so long as the rate of return on the domestic investment is sufficient to service the external debt. National saving "shortages", on 
this view, are only a problem if the dynamics of external debt threaten sustainability. International financial market liberalisation and integration has so far facilitated the capital flows necessary to allow persisting national saving/investment gaps, but concern has been expressed about the continued financing of such gaps because of the interest-rate and exchange-rate implications.

\section{Private saving}

The decline in household saving rates during the $1980 \mathrm{~s}$ has been particularly pronounced in North America, the United Kingdom, the Nordic countries (where negative rates have occurred), Australia and New Zealand -- mostly countries where there has been some domestic financial liberalisation. In a few countries -- Germany, Austria, the Netherlands and Switzerland -- there has been no decline or even a rise. For most countries the fall is also associated with disinflation and a strong rise in personal sector wealth since the early 1980s, in part reflecting the long bull market for equities (even taking account of the October $1987 \mathrm{crash}$ ) and in part reflecting the house price boom in certain countries.

Against the background of the strong rise in the value of personal sector assets and financial deregulation, there has been an increase in personal sector debt/income ratios. However, the distribution of assets and debt may differ substantially, so that rising debt and interest burdens for some households could precipitate general financial difficulties. In most of the economies where personal debt has grown rapidly, economic growth is currently strong, although there is a question about its sustainability given inflation pressures and external account problems. In current circumstances, with monetary policy being directed towards dealing with inflationary pressures, there are clearly greater risks for those individuals and companies which are now highly leveraged.

Increases in household net worth are, inter alia, a reflection of improved profits and business saving. Private saving rates have declined much less than household saving in the 1980 s since business saving, reflecting the profits recovery, has picked up strongly in recent years. It would seem that the "corporate veil" is indeed pierced although there has been a sharp fall in overall private saving rates in a few countries in the last two years.

\section{Government saving and tax policy}

One of the main features of the trend fall in national saving rates between the $1960 \mathrm{~s}$ and $1980 \mathrm{~s}$ was the reduction in the contribution of government saving to national saving. This decline in government saving, which has only recently been reversed in some countries, has not in general been offset to any great extent by private saving. Hence, strict "Ricardian equivalence" does not appear to have occurred, although there is much stronger evidence of important offsets where public sector deficits have been rather high, suggesting some sort of threshold effect.

Government decisions influence the level and allocation of national saving and investment in many ways. The public provision of social programmes is likely to reduce private saving that would otherwise be committed to expenditure on pension, health or education requirements. Differential tax 
treatment of different forms of private saving or investment can lead to a misallocation of resources, a sub-optimal composition of the capital stock and considerable welfare losses.

The increased access to liquidity and reduced spreads on consumer or housing loans may have discouraged saving while distortions in the tax system may have meant that additional expenditure has been directed to areas where there is the greatest tax relief. Financial market liberalisation, in the context of tax structures which commonly encourage housing, may have encouraged overinvestment in housing at the expense of productive investment. The interaction of financial market liberalisation and tax distortions should not however be taken as an argument for slowing or reversing the deregulation of financial markets but rather as an argument for pushing ahead with further reforms of tax systems. 
1. Depreciation is only one of the areas where measurement issues arise. There are other important issues such as the effect of inflation on measured national income and saving which are explicitly raised in the case of household saving in Section III.C and Annex III. Moreover, the way countries elaborate their national accounts sometimes differs conceptually. To alleviate some of these problems and to facilitate cross-country comparisons, this paper uses system of National Accounts (SNA) data which ensure better consistency. In some countries, however, SNA data are only available with some lag so that national data have occasionally been used to illustrate the most recent trends.

2. Neoclassical growth theory suggests that the capital stock should expand at a rate which equates the marginal productivity of capital with the economy's growth rate. But, in practice, measurement problems make it difficult to answer questions about dynamic efficiency (see Abel, Mankiw, Summers and zeckhauser (1989)).

3. The Schumpeterian view is that it is technical progress, in the form of product and process innovation, that causes high investment rather than the other way round.

4. The proposed revision to the SNA will treat R\&D expenditures as investment. See Blades (1989).

5. Rates of return, profit shares and capacity utilisation are shown in Tables 52 and 53 and Chart $K$ in OECD Economic Outlook 45, June 1989.

6. While saving for the whole OECD was always greater than investment from 1960 to 1973 and the difference never larger than 1 to 2 per cent of total area capital formation, saving was usually lower afterwards. Large swings occurred at the time of the two oil price shocks. Capital inflows from the rest of the world financed 3 per cent of total OECD capital formation in 1980. In the aftermath of the second oil price shock and the developing country debt crisis, the aggregate saving/investment imbalance was not redressed. In 1987 rest of the world capital inflows still financed 4 per cent of the OECD's capital formation.

7. Recent research has concluded that differences in risk-adjusted rates of return on assets denominated in the same currency but issued in different countries are arbitraged away quickly in the absence of strict capital controls. Bilateral correlations show that ex-ante real interest rates tend to move together and that there was a clear tendency towards convergence from the early to the mid-1980s. See R. Cumby and F. Mishkin (1985) and M. Obstfeld (1985).

8. In addition to consolidation efforts, privatisation generated a considerable amount of funds during the $1980 \mathrm{~s}$ in a number of countries though it would not have altered public sector net worth. 
9. For some recent discussion of Ricardian equivalence, see Leiderman and Blejer (1987) and Barro (1988).

10. Nicoletti (1988).

11. The household saving ratios used here and in the following paragraphs are those derived from the system of National Accounts. (SNA). These sometimes differ from national definitions. For the United states, for instance, measured household saving in SNA adds estate and gift taxes and saving by government employers in state and local government pension funds to the national definition of personal saving.

12. For example, depreciation is valued at historical cost in Japan and at replacement cost in the United States. In Canada, depreciation is estimated on an historical-cost basis except for housing, agriculture and government which are estimated on a replacement-cost basis.

13. The adjustment for inflation is obtained by multiplying the current rate of inflation by the preceding period's stock of net monetary assets held by the household sector. The definition of net monetary assets includes bonds. Hill (1984) indicates that "while the price of long-term bonds may change significantly during any individual accounting period, over the long term they share the characteristics of monetary assets whose real value is continually eroded by inflation". See also Hibbert, (1983) and Cukierman and Mortensen (1983). Changes in the private consumption deflator have been used to measure inflation.

14. The income usually associated with the saving decision in economic theory is the "economic" or "Hicksian" income which is defined as "the maximum value which a person can consume during a given period and still expect to be as well-off at the end of the period as he was at the beginning" (Hicks, 1946). See also Hill (1984).

15. See Ando and Modigliani (1963).

16. For a survey on the determinants of saving, see sturm (1983).

17. This effect was discussed by the Working Party at its October 1988 meeting (see CPL/WPI (88)6); see also Hagemann and Nicoletti (1989).

18. See, for example, Horioka (1986) and Kawasaki (1989) for a discussion of such social and demographic effects on Japanese household saving ratios, and Kaufmann (1988) for Germany and the United States.

19. See Reforming public pensions, OECD (1988).

20. Belgium, France, Gexmany, Japan, Sweden, the United Kingdom, Italy and the United States are the countries included in Tullio and Contesso's study.

21. In the OECD's INTERLINK model, the consumption function for the major seven countries, apart from the United states (see next note), includes the inflation rate as an explanatory variable. The inflation term proxies both inflation-induced wealth effects and the effect of the 
inflation adjustment discussed in paragraph 52. The semi-elasticity of household saving ratios with respect to a 1 point increase in the inflation rate varies from 0.11 in France to 0.45 in Japan and Germany. See Richardson (1987).

22. There is a large body of literature on the effects of wealth on household saving and consumption. See, for instance, Simes and Horn (1986) and Holtham and Kato (1986). Numerous empirical studies have been conducted which include household net worth as a determinant of saving and many national models now include wealth variables in their equations for private consumption. The OECD's INTERLINK model has a wealth term in the U.S. consumption function with an elasticity of 0.05 .

23. See Carroll and sumers (1987). The sudden decline in the net worth/income ratio in Canada in 1980 and in the household saving ratio in 1982 can be explained by a property boom and bust in the late 1970s followed by the most severe recession of all OECD countries in 1981-82.

24. Muellbauer and Murphy (1988); and Calverley and Datta (1988).

25. A recent Bank of France study shows that the inclusion of a credit variable improves the tracking performance of a standard consumption function in recent years -- Banque de France, "Analyse Econometrique de l'Influence des Credit de Trésorerie aux Particuliers sur la Consommation des Ménages". mimeo, 3rd May 1988.

26. Summers and Carroll (1987).

27. Shields (1988).

28. Canner, et al. (1988).

29. In the years prior to the purchase of a house, for example, savings are being accumulated to meet deposit requirements. But in the years immediately after the purchase, interest payments, which are treated as a deduction in calculating disposable income, are normally much larger than principal repayments (which are treated as saving) so that saving is likely to be low.

30. Gabriel (1987).

31. See Table 4 in Hagemann et al. (1987) which summarises simulation results of tax changes and also Kotlikoff (1984) and Borges (1986).

32. The deductibility of mortgage interest is the single most costly expense-related taxation relief in most countries. In the United States, mortgage interest payments are fully tax deductible and although the Tax Reform Act of 1986 provided for the gradual phasing-out of tax deductions allowed for interest on consumer debt, interest paid on loans secured by a home is still tax deductible within specified but fairly generous limits. In the United Kingdom tax relief is available against interest payments on the first $£ 30,000$ of housing mortgages. In Australia mortgage interest payments for owner-occupied housing are not tax deductible, but interest payments on borrowing for 
an investment property are fully tax deductible against all income: In Sweden there is full deductibility of all interest payments on both mortgages and consumer debt although it is not possible to have tax relief that amounts to more than 47 per cent of interest payments. In Denmark mortgage interest payments are deductible with a maximum tax value of 50 per cent, while the tax value of other consumer interest payments was reduced in late 1986 to a maximum value of 30 per cent. In Finland up to 25,000 Finnish marka of mortgage interest payments and 10,000 Finnish marka for other consumer loans are fully tax deductible; for the typical household the mortgage deduction is sufficient to cover annual mortgage interest payments. In Norway all interest payments of households are deductible for tax purposes. 


\section{RETERHCES}

Abel, A., G. Mankiw, L. Summers and R. Zeckhauser (1989), "Assessing dynamic efficiency: theory and evidence", Review of Economic studies, Vol. 56, Pp. $1-20$.

Ando, A. and F. Modigliani (1963), "The life cycle hypothesis of saving: aggregate implications and tests", American Economic Review, Vol. 53 (March), pp. 55-84.

Aschauer, D. (1988), "Is public expenditure productive?", Federal Reserve Bank of Chicago, Vol. 88, No. 7 .

Auerbach, A.J. and I. Kotlikoff (1987), Dynamic fiscal policy, Cambridge: Cambridge University Press.

Auerbach, A.J. and I. Kotlikoff (1983), "National savings, economic welfare and the structure of taxation" in M.S. Feldstein (ed.), Behavioural simulation methods in tax policy analysis, Chicago University Press.

Barnes, R.O. and R. Gillingham (1984), "Demographic effects in demand analysis: estimation of the quadratic expenditure system using micro data", Review of Economics and Statistics, Vol. 66, No.4 (November), Pp. 598-601.

Barro, R. (1978), The impact of social security on private saving, Washington: American Enterprise Institute.

Barro, R. (1988), "The Ricardian approach to budget deficits", NBER Working Paper No.2685 (August).

Beach, C., R. Boadway and N. Bruce (1986), "Taxation and saving in Canada", a study for the Economic Council of Canada.

Bentzel, R. and L. Berg (1983), "The role of demographic factors as a determinant of saving", in R. Hemmings (ed.), National saving and wealth, London: MaMilian.

Blades, D. (1983), "Alternative measures of saving", OECD Occasional Studies (June), PP. 66-84.

Blades, D. (1989), "Revision of the system of National Accounts", OECD Economic studies, No.12, (forthcoming).

Borges, A. (1986), "Applied general equilibrium models: an assessment of their usefulness for policy analyses", OECD Economic studies (Autumn), PP. 7-43).

Boskin, M. (1978), "Taxation, saving and the rate of interest", Journal of Political Economy, Vol. 86 (April), pp. S3-527.

Boskin, M. (1988), "Issues in the measurement and interpretation of saving and wealth", NBER Working Paper No. 2633 (June). 
Boskin, M., L. Kotlikoff and M. Knetter (1985), "Changes in the age distribution of income in the United States", NBER Working Paper No. 1766 .

Boskin, M. and L. Lau (1978), "An analysis of postwar U.S. consumption and saving behaviour", mimeo., Stanford University, cited in Boskin (1988).

Brugiavini, A. (1987), "Empirical evidence on wealth accumulation and the effects of pension wealth: an application to Italian cross-section data", mimeo.

Calverley, J. and T. Datta (1988), "The U.K. consumer: savings, debt and the housing market", AMEX Bank Review, No.15 (September).

Canner, G.B., J. Fergus and I. Luckett (1988), "Home equity lines of credit", Federal Reserve Bulletin (June), pp. 361-73.

Carroll, C. and I. Summers (1987), "Why have private savings rates in the United States and Canada diverged?", Journal of Monetary Economics, (20), pp. 249-79.

Christine, M. (1988), "L'endettement des ménages", Revue Banque No.489 (Decembex) .

Cukierman, A. and J. Mortensen (1983), "Monetary assets and inflation-induced distortions of the national accounts -- conceptual issues and correction of sectoral income flows in 5 EEC countries", EEC Economic Papers (June).

Cumby, R. and F. Mishkin (1985), "The international linkage of real interest rates: the European-US. connection", Journal of International Money and Finance, 4.

David, A. and J. Scadding (1974), "Private savings: ultrarationality, aggregation and Denison's law", Journal of Political Economy, Vol. 82, March-April 1974, pp. 225-49.

Denison, E.F. (1958), "A note on private saving", Review of Economics and Statistics, No.40 (August), pp. 261-267.

Dicks, M.J. (1988), "The interest elasticity of consumer's expenditure", Bank of England Working Paper No.20 (December).

Englander, A.S. and A. Mittelstädt (1988), "Total factor productivity; macroeconomic and structural aspects of the slowdown", OECD EConomic Studies, No.10 (Spring).

Feldstein, M. and C. Horioka (1980), "Domestic saving and international capital flows", The Economic Journal, 90 (June).

Feldstein, M. and A. Pellochio (1978), "Social security and household wealth accumulation: new microeconomic evidence", The Review of Economics and Statistics, pp. 361-68. 
Fukao, M. and M. Hanazaki (1987), "Internationalisation of financial markets and the allocation of capital", QECD Economic Studies (Spring), pp. 35-92.

Gabriel, S.A. (1987), "Housing and mortgage markets: the post 1982 expansion", Federal Reserve Bulletin (December), pp. 893-903.

Goulder, L. and B. Eichengreen (1988), "Saving promotion, investment promotion and international competitiveness", NBER Working Paper No. 2635 (June).

Graham, J.W. (1987), "International differences in saving rates and the life cycle hypothesis", European Economic Review, No.31, pp. 1509-29.

Hagemann, R., B. Jones and B. Montador (1987), "Taxation reform in OECD countries: economic rationale and consequences", OECD Working Papers No. 40 (August).

Hagemann, R. and G. Nicoletti (1989), "Ageing populations: economic effects and implications for public finance", OECD Working Papers No.61 (January) .

Hall, R.E. (1985), "Real interest and consumption", NBER Working Paper No.1694 (August).

Haydu, G. (1987), "Inflation adjustments to the national income and expenditure accounts", Canadian Statistics Review (August).

Heller, P. (1988), "Ageing, savings, pensions in the G7 countries: 1980-2025", IMF Working Paper (January).

Hibbert, J. (1983), "Measuring the effects of inflation on income saving and wealth".

Hicks, J.R. (1946), Value and capital, Oxford: Clarendon Press 2nd edition.

Hill, T.P. (1984), "Inflation, holding gains and saving" OECD Economic Studies, No.2 (Spring), pp. 151-164.

Hill, T.P. (1988), "The concept of income and the distinction between current and capital items", OECD, mimeo.

Holtham, G.H. and H. Kato (1986), "Wealth and inflation effects in the aggregate consumption function", OECD Working Papers No.35 (July).

Horioka, C.Y. (1986), "Why is Japan's private saving rate so high", IMF, mimeo.

Jump, G.V. (1980), "Interest rates, inflation expectations and spurious elements in measured real income and saving", American Economic Review, vol. 70, No.4, pp. 990-1004.

Kaskela, E. and M. Viren (1983), "Social security and household saving in an international cross section", American Economic Review (March), pp. 212-217. 
Kauffmann, B. (1988), "Zum Sparverhalten der privaten Haushalte in der Bundesrepublik Deutschland und in den Vereingten Staaten", Die Weltwirtschaft, 2, 53-62.

Kawasaki, K. (1989), "Japanese saving; a survey of the literature", mimeo., OECD (February).

Kessler, D. (1989), "L'endettement des français" in Le Monde (10th January).

Kotlikoff, I.J. (1984), "Taxation and savings: a neoclassical perspective", Journal of Economic Literature, Vol. XXII, No. 4 (December), pp. 1576-1629.

Kotlikoff, I.J. (1988), "Intergenerational transfers and saving", Journal of Economic Rerspectives, No.2 (Spring), pp. 41-58.

Leiderman, L. and M. Blejer (1987), "Modelling and testing Ricardian equivalence: a survey", IMF Working Paper No. $87 / 35$ (April)

Leimer, D.C. and S. Lesnoy (1982), "Social security and private saving: new time series evidence", Journal of Political Economy, Vol.90, No.3, pp. 606-629.

Maddison, A. (1987), "Growth and slowdown in advanced capitalist economies: techniques of quantitative assessment", Journal of Economic Literature (June), PP. 649-98.

Modigliani, F. (1986), "Iife cycle, individual thrift, and the wealth of nations", American Economic Review, Vol.76, No.3 (June), pp. 297-313.

Muellbauer, J. and A. Murphy (1988), "U.K. house prices and migration: economic and investment implications", Shearson Lehman Hutton Securities, Iondon (November).

Musgrove, P. (1982), U.S. household consumption, income and demographic changes; 1975-2025, Washington.

Nicoletti, G. (1988), "A cross-country analysis of private consumption, inflation and the debt neutrality hypothesis", OECD Economic Studies No. 11 (Autumn), pp. 43-87.

Obstfeld, M. (1985), "Capital mobility in the world economy: theory and measurement", NBER Working Paper No. 1692 (August).

OECD (1988), Reforming public pensions.

Poterba, J. (1987), "Tax policy and corporate saving", Brookings Papers on Economic Activity, 2, pp. 455-503.

Richardson, P. (1987), "Recent developments in OECD's international macroeconomic model", OECD Working Papers No.46 (June). 
Schultze, C.L. (1988), "Setting long-run deficit reduction targets: the economics and politics of budget decision", paper delivered to a meeting of the National Academy of Social Insurance, Washington, (December).

Shibuya, H. (1987), "Japan's household savings rate: an application of the life cycle hypothesis", IMF Working Paper No.87/15 (March).

Shields, J. (1988), "Controlling household credit", National Institute Economic Review (August), pp. 46-55.

Simes, R.M. and P.M. Horn (1986), "Wealth, inflation and the consumption function", paper presented at the 15th Conference of economists at Monash University.

Stiglitz, J. and A. Weiss (1981), "Credit rationing in markets with imperfect competition", American Economic Review, Vol. 71, pp. 393-411.

Sturm, P. (1983), "Determinants of saving theory and evidence", OECD EConomic Studies No.1 (Autumn), pp. 147-196.

Summers, L. and C. Carroll (1987), "Why is U.S. national saving so low", Brookings Papers on Economic Activity, 2, pp. 607-642.

Taylor, L.O. (1971), "Saving out of different types of income", Brookings Papers on Economic Activity, No.2, pp. 383-407.

Tullio, G. and F. Contesso (1986), "Do after-tax interest rates affect private consumption and saving? Empirical evidence for eight industrialised countries: 1970-83", Commission of the European Communities, Discussion Raper No. 51 .

Turner, P. (1986), "Savings, investment and the current account: an empirical study of seven major countries 1965-1984", Bank of Japan Monetary and Economic studies (October), pp. 1-58.

Venti, S.F. and D.A. Wise (1987), "IRAs and saving", in Feldstein, M. (ed.), The effects of taxation on capital accumulation, University of Chicago Press.

Williamson, J. (1985), The exchange rate system, Institute of International Finance, Washington.

Wolff, E. (1987), "Capital formation and long-term productivity growth", Working Paper, C.V. Starr Centre for Applied Economics, New York University. 
Sable 1

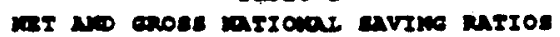

(a) par cont of net and roos netsonel probuct)

\begin{tabular}{|c|c|c|c|c|c|c|}
\hline \multirow[b]{3}{*}{ Onsted stater } & \multirow[b]{3}{*}{$\begin{array}{l}\text { Mot } \\
\text { oroes }\end{array}$} & \multicolumn{3}{|c|}{ Arezages } & \multirow{2}{*}{2906} & \multirow{2}{*}{2907} \\
\hline & & $1960-70$ & $2271-80$ & $2981-07$ & & \\
\hline & & $\begin{array}{l}10.6 \\
19.6\end{array}$ & $\begin{array}{r}6.9 \\
29.5\end{array}$ & $\begin{array}{r}3.9 \\
26.3\end{array}$ & $\begin{array}{r}2.0 \\
15.0\end{array}$ & $\begin{array}{r}2.7 \\
24.6\end{array}$ \\
\hline Japan & $\begin{array}{l}\text { Not } \\
\text { exose. }\end{array}$ & $\begin{array}{l}23.6 \\
33.0\end{array}$ & $\begin{array}{l}24.6 \\
34.4\end{array}$ & $\begin{array}{l}20.2 \\
31.1\end{array}$ & $\begin{array}{l}20.0 \\
31.0\end{array}$ & $\begin{array}{l}21.3 \\
32.2\end{array}$ \\
\hline Cormeny & $\begin{array}{l}\text { Mot } \\
\text { aroes }\end{array}$ & $\begin{array}{l}19.9 \\
27.3\end{array}$ & $\begin{array}{l}24.3 \\
23.7\end{array}$ & $\begin{array}{l}10.7 \\
21.0\end{array}$ & $\begin{array}{l}13.1 \\
23.8\end{array}$ & $\begin{array}{l}13.0 \\
23.7\end{array}$ \\
\hline Pranoe & Crose: & 26.3 & 23.4 & 19.6 & 10.1 & 19.6 \\
\hline Dnited Rungdon & $\begin{array}{l}\text { Mot } \\
\text { Gropes }\end{array}$ & $\begin{array}{l}11.2 \\
18.7\end{array}$ & $\begin{array}{r}0.2 \\
10.1\end{array}$ & $\begin{array}{r}6.2 \\
17.5\end{array}$ & $\begin{array}{r}5.6 \\
26.9\end{array}$ & $\begin{array}{r}6.1 \\
27.1\end{array}$ \\
\hline Italy & $\begin{array}{l}\text { Hot } \\
\text { Oroee }\end{array}$ & $\begin{array}{l}13.0 \\
21.0\end{array}$ & $\begin{array}{l}12.1 \\
19.2\end{array}$ & $\begin{array}{r}7.5 \\
15.6\end{array}$ & $\begin{array}{l}\cdots \\
\cdots\end{array}$ & $\ddot{*}$ \\
\hline Canede & $\begin{array}{l}\text { Not } \\
\text { Groos }\end{array}$ & $\begin{array}{l}11.3 \\
21.0\end{array}$ & $\begin{array}{l}13.3 \\
23.1\end{array}$ & $\begin{array}{r}9.1 \\
20.3\end{array}$ & $\begin{array}{r}7.6 \\
18.9\end{array}$ & $\begin{array}{r}0.3 \\
29.4\end{array}$ \\
\hline Auotrie & $\begin{array}{l}\text { Not } \\
\text { Groos }\end{array}$ & $\begin{array}{l}18.2 \\
28.0\end{array}$ & $\begin{array}{l}18.0 \\
27.6\end{array}$ & $\begin{array}{l}13.0 \\
23.8\end{array}$ & $\begin{array}{l}13.2 \\
24.0\end{array}$ & $\begin{array}{l}23.5 \\
24.3\end{array}$ \\
\hline Delgive & $\begin{array}{l}\text { Net } \\
\text { Gron: }\end{array}$ & $\begin{array}{l}14.4 \\
22.6\end{array}$ & $\begin{array}{l}23.0 \\
21.8\end{array}$ & $\begin{array}{r}6.5 \\
25.2\end{array}$ & $\begin{array}{r}7.9 \\
16.4\end{array}$ & $\begin{array}{r}9.0 \\
17.2\end{array}$ \\
\hline Donmark & $\begin{array}{l}\text { Mot } \\
\text { Grose }\end{array}$ & $\begin{array}{l}17.4 \\
23.2\end{array}$ & $\begin{array}{l}23.3 \\
20.3\end{array}$ & $\begin{array}{r}6.0 \\
14.8\end{array}$ & $\begin{array}{r}6.3 \\
26.7\end{array}$ & $\begin{array}{r}7.3 \\
16.2\end{array}$ \\
\hline Tinland & $\begin{array}{l}\text { Not } \\
\text { Groes: }\end{array}$ & $\begin{array}{l}25.7 \\
25.6\end{array}$ & $\begin{array}{l}24.2 \\
26.7\end{array}$ & $\begin{array}{l}10.7 \\
24.1\end{array}$ & $\begin{array}{r}0.5 \\
23.1\end{array}$ & $\begin{array}{r}9.3 \\
23.0\end{array}$ \\
\hline Groese & $\begin{array}{l}\text { Not } \\
\text { Groe. }\end{array}$ & $\begin{array}{l}15.3 \\
19.7\end{array}$ & $\begin{array}{l}20.7 \\
26.2\end{array}$ & $\begin{array}{r}0.5 \\
16.3\end{array}$ & $\begin{array}{r}3.4 \\
14.1\end{array}$ & $\begin{array}{r}6.1 \\
14.0\end{array}$ \\
\hline Ireland & $\begin{array}{l}\text { Mot } \\
\text { eroes }\end{array}$ & $\begin{array}{l}12.0 \\
10.6\end{array}$ & $\begin{array}{l}13.1 \\
21.0\end{array}$ & $\begin{array}{r}8.3 \\
18.3\end{array}$ & $\begin{array}{r}7.9 \\
17.8\end{array}$ & $\begin{array}{l}11.1 \\
20.7\end{array}$ \\
\hline Hothorlando & $\begin{array}{l}\text { Not } \\
\text { eroes }\end{array}$ & $\begin{array}{l}29.9 \\
26.9\end{array}$ & $\begin{array}{l}16.4 \\
23.9\end{array}$ & $\begin{array}{l}13.3 \\
22.2\end{array}$ & $\begin{array}{l}14.6 \\
23.2\end{array}$ & $\begin{array}{l}12.8 \\
21.0\end{array}$ \\
\hline Norway & $\begin{array}{l}\text { Mot } \\
\text { oxoos }\end{array}$ & $\begin{array}{l}16.1 \\
27.5\end{array}$ & $\begin{array}{l}16.0 \\
27.0\end{array}$ & $\begin{array}{l}15.8 \\
20.2\end{array}$ & $\begin{array}{l}10.6 \\
23.5\end{array}$ & $\begin{array}{l}20.5 \\
23.0\end{array}$ \\
\hline Portugal & $\begin{array}{l}\text { Mot } \\
\text { Growe }\end{array}$ & $\begin{array}{l}19.0 \\
23.9\end{array}$ & $\begin{array}{l}22.0 \\
25.6\end{array}$ & $\begin{array}{l}28.0 \\
23.0\end{array}$ & $\begin{array}{l}23.6 \\
27.0\end{array}$ & $\begin{array}{l}24.9 \\
20.3\end{array}$ \\
\hline Spain & $\begin{array}{l}\text { Not } \\
\text { Orosen }\end{array}$ & $\begin{array}{l}26.7 \\
25.5\end{array}$ & $\begin{array}{l}26.7 \\
25.0\end{array}$ & $\begin{array}{r}9.6 \\
20.3\end{array}$ & $\begin{array}{l}12.5 \\
21.7\end{array}$ & $\begin{array}{l}12.4 \\
22.1\end{array}$ \\
\hline Mrodon & $\begin{array}{l}\text { Wot } \\
\text { Groses }\end{array}$ & $\begin{array}{l}16.6 \\
25.0\end{array}$ & $\begin{array}{l}21.8 \\
22.1\end{array}$ & $\begin{array}{r}6.0 \\
17.2\end{array}$ & $\begin{array}{r}7.3 \\
16.3\end{array}$ & $\begin{array}{r}7.4 \\
18.3\end{array}$ \\
\hline sutsensland & $\begin{array}{l}\text { Mot } \\
\text { oxoses }\end{array}$ & $\begin{array}{l}21.2 \\
29.6\end{array}$ & $\begin{array}{l}29.4 \\
20.0\end{array}$ & $\begin{array}{l}20.2 \\
20.0\end{array}$ & $\begin{array}{l}22.3 \\
29.7\end{array}$ & $\begin{array}{l}22.9 \\
30.4\end{array}$ \\
\hline Aontralia & $\begin{array}{l}\text { Not } \\
\text { exose. }\end{array}$ & $\begin{array}{l}23.7 \\
24.8\end{array}$ & $\begin{array}{l}11.0 \\
23.2\end{array}$ & $\begin{array}{r}3.4 \\
19.3\end{array}$ & $\begin{array}{r}3.4 \\
18.7\end{array}$ & $\begin{array}{r}3.5 \\
21.6\end{array}$ \\
\hline Mon zaeland & $\begin{array}{l}\text { not } \\
\text { aroes }\end{array}$ & $\begin{array}{l}14.2 \\
21.2\end{array}$ & $\begin{array}{l}13.0 \\
21.0\end{array}$ & $\begin{array}{r}14.6 \\
21.5\end{array}$ & $\begin{array}{l}14.0 \\
22.0\end{array}$ & $\begin{array}{l}14.0 \\
21.2\end{array}$ \\
\hline $\begin{array}{l}\text { Average of } \\
\text { above countrine }\end{array}$ & $\begin{array}{l}\text { Mot } \\
\text { Oxoes }\end{array}$ & $\begin{array}{l}24.6 \\
23.3\end{array}$ & $\begin{array}{l}13.5 \\
23.5\end{array}$ & $\begin{array}{r}6.7 \\
20.2\end{array}$ & $\begin{array}{r}0.5 \\
19.0\end{array}$ & $\begin{array}{r}0.5 \\
18.7\end{array}$ \\
\hline
\end{tabular}

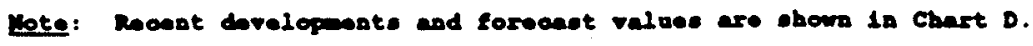

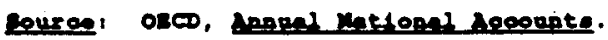


Table 2

RELATION BETWEEN NATIONAL SAVING AND INVESTMENT RATIOS (a)

\begin{tabular}{lccc}
\hline Period & Constant & $S / Y$ & $R^{2}$ \\
\hline & & & \\
1963.67 & 0.033 & 0.91 & 0.90 \\
& $(0.016)$ & $(0.064)$ & \\
$1968-72$ & 0.053 & 0.80 & 0.82 \\
& $(0.020)$ & $(0.079)$ & \\
$1973-77$ & 0.077 & 0.77 & 0.44 \\
& $(0.044)$ & $(0.181)$ & \\
1978.82 & 0.085 & 0.71 & 0.47 \\
& $(0.035)$ & $(0.156)$ & \\
1983.87 & 0.094 & 0.58 & 0.61 \\
& $(0.021)$ & $(0.098)$ & \\
\hline
\end{tabular}

a) Pooled data for 23 OECD countries. The regression is: $\quad I_{i} / Y_{i}=\alpha+\beta\left[S_{i} / Y_{i}\right]$. where $I_{i}, S_{i}$ and $Y_{i}$ are domestic investment, saving and income in country i. For countries with a statistical discrepancy, it is split between saving and investment. Investment and saving ratios are averaged over the subperiods. Standard errors are shown below coefficients.

Source: OECD. Annual National Accounts. 
Table 3

GOVERMMENT BAVING NND DIBBAVING

(por cent of GNP)

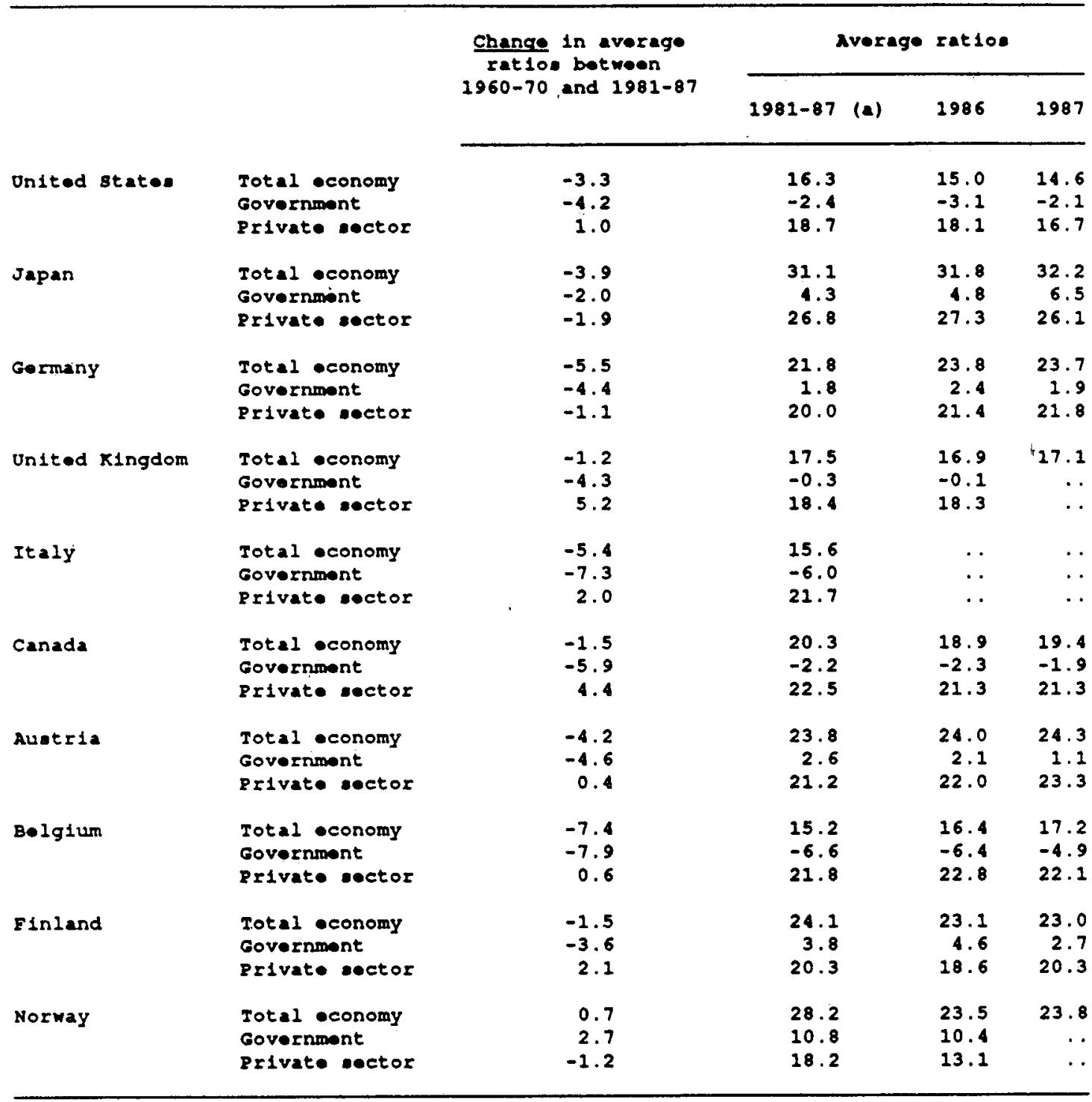

a) Averagea to 1987 or lateat ava1lable date.

Note: Only countriee with date for grose eaving ration covering the ent1re period are included in this table. Additional detall, both for these and other countries, a) well a important notes about the comparability of the perien, are given in Table Al. Recent developmente and forecast values are shown in Chart $D$.

Source: OECD, Annual National Accounte. 
Table 4

PUBLIC SECTOR CLAIMS ON PRIVATE SAVING

(Ratio of the general government deficit to gross private saving)

\begin{tabular}{|c|c|c|c|c|c|}
\hline & \multicolumn{2}{|c|}{ Averages } & \multirow{2}{*}{1986} & \multirow{2}{*}{1987} & \multirow{2}{*}{1988} \\
\hline & $1971-80$ & $1981-87$ & & & \\
\hline $\begin{array}{l}\text { United States } \\
\text { Japan } \\
\text { Germany } \\
\text { France } \\
\text { United Ringdom } \\
\text { Italy } \\
\text { Canada }\end{array}$ & $\begin{array}{r}5.4 \\
7.9 \\
9.9 \\
1.9 \\
14.6 \\
\ldots \\
5.6\end{array}$ & $\begin{array}{r}17.0 \\
8.2 \\
11.3 \\
14.3 \\
14.4 \\
39.5 \\
24.8\end{array}$ & $\begin{array}{r}21.2 \\
4.1 \\
6.1 \\
14.9 \\
13.2 \\
39.0 \\
26.5\end{array}$ & $\begin{array}{r}15.7 \\
1.2 \\
8.1 \\
13.5 \\
7.9 \\
39.8 \\
22.4\end{array}$ & $\begin{array}{r}12.0 \\
0.8 \\
8.4 \\
8.2 \\
-2.0 \\
38.7 \\
16.0\end{array}$ \\
\hline $\begin{array}{l}\text { Austria } \\
\text { Belgium } \\
\text { Denmark } \\
\text { Finland } \\
\text { Netherlands } \\
\text { Norway } \\
\text { Spain } \\
\text { Sweden } \\
\text { Australia }\end{array}$ & $\begin{array}{r}4.4 \\
23.2 \\
-6.1 \\
-17.1 \\
10.0 \\
-19.8 \\
. . \\
-13.4 \\
1.9\end{array}$ & $\begin{array}{r}14.8 \\
46.8 \\
18.7 \\
0.4 \\
26.1 \\
-36.0 \\
25.8 \\
14.8 \\
10.4\end{array}$ & $\begin{array}{r}16.9 \\
40.1 \\
-28.3 \\
-3.8 \\
24.7 \\
-47.0 \\
27.7 \\
4.8 \\
12.9\end{array}$ & $\begin{array}{r}18.0 \\
32.6 \\
-19.3 \\
4.3 \\
26.7 \\
-29.2 \\
18.3 \\
-40.8 \\
3.6\end{array}$ & $\begin{array}{r}12.0 \\
30.2 \\
-9.4 \\
-6.6 \\
22.9 \\
-12.8 \\
17.0 \\
-45.4 \\
-6.6\end{array}$ \\
\hline $\begin{array}{l}\text { Average of above } \\
\text { countries (excluding } \\
\text { Italy and Spain) }\end{array}$ & 6.6 & 14.6 & 14.4 & 10.6 & 7.2 \\
\hline
\end{tabular}

Note: Negative sign indicates a budget surplus, a positive sign a budget deficit.

Source: OECD. Annual National Accounts. For the recent period, data are based on OECD estimates published in Economic Outlook 44. 
Yable 5

MET AND GROBS PRTVATE BAVTNG RATIOB

(por cont of not and grose natlonel product)

\begin{tabular}{|c|c|c|c|c|c|c|}
\hline \multirow[b]{3}{*}{ Dnsted states } & \multirow[b]{3}{*}{$\begin{array}{l}\text { Hot } \\
\text { Grose }\end{array}$} & \multicolumn{3}{|c|}{ Averagen } & \multirow{2}{*}{2986} & \multirow{2}{*}{1987} \\
\hline & & $1960-70$ & $1971-80$ & $1981-87$ (a) & & \\
\hline & & $\begin{array}{r}9.9 \\
17.7\end{array}$ & $\begin{array}{l}10.2 \\
19.2\end{array}$ & $\begin{array}{r}8.1 \\
18.7\end{array}$ & $\begin{array}{r}7.8 \\
18.1\end{array}$ & $\begin{array}{r}6.4 \\
26.7\end{array}$ \\
\hline Japan & $\begin{array}{l}\text { Not } \\
\text { Groses }\end{array}$ & $\begin{array}{l}18.9 \\
28.7\end{array}$ & $\begin{array}{l}20.1 \\
29.9\end{array}$ & $\begin{array}{l}15.9 \\
26.8\end{array}$ & $\begin{array}{l}16.2 \\
27.3\end{array}$ & $\begin{array}{l}24.4 \\
26.1\end{array}$ \\
\hline Cormany & $\begin{array}{l}\text { Net } \\
\text { Grose }\end{array}$ & $\begin{array}{l}13.5 \\
21.1\end{array}$ & $\begin{array}{l}11.0 \\
20.2\end{array}$ & $\begin{array}{r}9.4 \\
20.0\end{array}$ & $\begin{array}{l}11.1 \\
21.4\end{array}$ & $\begin{array}{l}11.6 \\
21.8\end{array}$ \\
\hline France & Grose & $\cdots$ & 22.0 & 18.8 & 19.6 & 18.8 \\
\hline Onited Ringdom & $\begin{array}{l}\text { Not } \\
\text { Groose }\end{array}$ & $\begin{array}{r}6.4 \\
13.3\end{array}$ & $\begin{array}{r}8.1 \\
16.7\end{array}$ & $\begin{array}{r}0.6 \\
18: 4\end{array}$ & $\begin{array}{r}9.2 \\
18.9\end{array}$ & $\begin{array}{r}8.2 \\
18.3\end{array}$ \\
\hline Italy & $\begin{array}{l}\text { Not } \\
\text { Grose }\end{array}$ & $\begin{array}{l}13.9 \\
29.7\end{array}$ & $\begin{array}{l}16.3 \\
22.9\end{array}$ & $\begin{array}{l}14.4 \\
21.7\end{array}$ & $\ddot{*}$ & $\because$ \\
\hline Canada & $\begin{array}{l}\text { Not } \\
\text { Groses }\end{array}$ & $\begin{array}{r}8.6 \\
28.1\end{array}$ & $\begin{array}{l}12.3 \\
20.7\end{array}$ & $\begin{array}{l}13.6 \\
22.5\end{array}$ & $\begin{array}{l}12.2 \\
21.3\end{array}$ & $\begin{array}{l}12.4 \\
21.3\end{array}$ \\
\hline dustria & $\begin{array}{l}\text { Net } \\
\text { Groses }\end{array}$ & $\begin{array}{l}10.9 \\
20.8\end{array}$ & $\begin{array}{l}12.2 \\
21.7\end{array}$ & $\begin{array}{l}10.9 \\
21.2\end{array}$ & $\begin{array}{l}11.8 \\
22.0\end{array}$ & $\begin{array}{l}13.2 \\
23.3\end{array}$ \\
\hline Bolgium & $\begin{array}{l}\text { Not } \\
\text { Grose }\end{array}$ & $\begin{array}{l}13.1 \\
21.2\end{array}$ & $\begin{array}{l}14.9 \\
22.5\end{array}$ & $\begin{array}{l}14.1 \\
21.8\end{array}$ & $\begin{array}{l}15.2 \\
22.8\end{array}$ & $\begin{array}{l}14.7 \\
22.1\end{array}$ \\
\hline Donmark & $\begin{array}{l}\text { Not } \\
\text { Grose }\end{array}$ & $\ddot{*}$ & $\begin{array}{r}8.1 \\
24.8\end{array}$ & $\begin{array}{r}8.0 \\
25.8\end{array}$ & $\begin{array}{r}3.0 \\
21.1\end{array}$ & $\ddot{\circ}$ \\
\hline Finland & $\begin{array}{l}\text { Not } \\
\text { Groese }\end{array}$ & $\begin{array}{r}8.2 \\
28.2\end{array}$ & $\begin{array}{r}6.7 \\
19.3\end{array}$ & $\begin{array}{r}7.6 \\
20.3\end{array}$ & $\begin{array}{r}5.6 \\
18.6\end{array}$ & $\begin{array}{r}7.7 \\
20.3\end{array}$ \\
\hline Grance & Not & 21.2 & 18.7 & 25.1 & 12.5 & 12.5 \\
\hline Netberlande & $\begin{array}{l}\text { Mot } \\
\text { aroes }\end{array}$ & 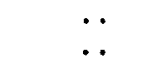 & $\begin{array}{l}13.8 \\
20.8\end{array}$ & $\begin{array}{l}24.9 \\
22.9\end{array}$ & $\begin{array}{l}26.1 \\
23.9\end{array}$ & $\begin{array}{l}14.6 \\
22.7\end{array}$ \\
\hline Norway & $\begin{array}{l}\text { Mot } \\
\text { oroses }\end{array}$ & $\begin{array}{r}7.4 \\
19.4\end{array}$ & $\begin{array}{r}4.9 \\
18.0\end{array}$ & $\begin{array}{r}5.8 \\
18.2\end{array}$ & $\begin{array}{r}0.3 \\
13.1\end{array}$ & $\ddot{*}$ \\
\hline smedon & $\begin{array}{l}\text { Not } \\
\text { Groses }\end{array}$ & $\ddot{x}$ & $\begin{array}{r}5.6 \\
14.3\end{array}$ & $\begin{array}{r}6.7 \\
16.5\end{array}$ & $\begin{array}{r}5.7 \\
15.4\end{array}$ & $\ddot{*}$ \\
\hline ewitzerland & Not & 16.1 & 15.2 & 16.3 & 17.5 & 18.2 \\
\hline awatralia & $\begin{array}{l}\text { Mot } \\
\text { exoes }\end{array}$ & $\because$ & $\begin{array}{l}10.7 \\
21.3\end{array}$ & $\begin{array}{r}4.8 \\
18.1\end{array}$ & $\begin{array}{r}3.7 \\
17.7\end{array}$ & 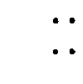 \\
\hline $\begin{array}{l}\text { Average of } \\
\text { above count riea }\end{array}$ & $\begin{array}{l}\text { not } \\
\text { axose }\end{array}$ & $\ddot{x}$ & $\begin{array}{l}11.9 \\
21.2\end{array}$ & $\begin{array}{l}20.2 \\
20.5\end{array}$ & $\begin{array}{l}10.3 \\
20.3\end{array}$ & $\ddot{m}$ \\
\hline
\end{tabular}

a) averagee to 1987 or lateat evaldable date.

Lete: Iecent doveloponte and lozeceat velues for groes private eaving ratioe are bhown in Chert $D$.

gource: OrCD, Annul watiend resounte. 
Table 6

VARIATION OE SAVING RATIOS

(Coefficients of variation across countries)

\begin{tabular}{lcc}
\hline $1960-70$ & $1971-80$ & $1981-87$ \\
\hline Net Gross & Net Gross & Net Gross
\end{tabular}

Major Seven Countries

$\begin{array}{lllllll}\text { National } & 0.35 & 0.22 & 0.40 & 0.22 & 0.54 & 0.24 \\ \text { Private } & 0.34 & 0.24 & 0.31 & 0.19 & 0.26 & 0.13 \\ & & & 0.43 & 0.35 & 0.38 & 0.30 \\ \begin{array}{l}\text { Households } \\ \text { Business }\end{array} & & & 0.55 & 0.26 & 0.70 & 0.26\end{array}$

Small Countries
National
$0.15 \quad 0.12$
0.20
0.10
0.46
0.20
Private
0.37
0.15
0.39
0.13

Note: The number of countries included in the calculation of coefficients of variation is constrained by data availability (see Annex Table Al). For the major seven countries, gross national saving is available for all seven countries; the other coefficients are based on six countries. National saving is available for 15 small countries and private saving for eight.

Source: OECD. Annual National Accounts. 
sable 7

DOsIness savnise (a)

(por cont of CDP)

\begin{tabular}{|c|c|c|c|c|c|c|c|}
\hline & & $1961-70$ & $2971-10$ & $1981-87$ & 2905 & 1986 & 1987 \\
\hline \multirow[t]{2}{*}{$\frac{\text { polted }}{\text { itated }}$} & $\begin{array}{l}\text { Defore-tax revonue } \\
\text { Direct taxes } \\
\text { otber current paymente } \\
\text { Intereat } \\
\text { Dividends } \\
\text { Mot eaving }\end{array}$ & $\begin{array}{r}12.2 \\
3.6 \\
0.3 \\
2.1 \\
3.4 \\
2.8\end{array}$ & $\begin{array}{r}12.1 \\
2.8 \\
0.4 \\
3.9 \\
3.2 \\
1.8\end{array}$ & $\begin{array}{r}13.3 \\
1.8 \\
0.5 \\
6.0 \\
3.2 \\
1.7\end{array}$ & $\begin{array}{r}13.6 \\
1.6 \\
0.5 \\
5.6 \\
3.1 \\
2.6\end{array}$ & $\begin{array}{r}12.9 \\
1.9 \\
0.5 \\
5.3 \\
3.1 \\
2.1\end{array}$ & $\begin{array}{l}\ddot{.} \\
\ddot{*} \\
\ddot{\cdots}\end{array}$ \\
\hline & Net londing & -1.0 & -2.7 & -0.5 & 0.2 & 0.1 & . \\
\hline \multirow[t]{2}{*}{ Inepen } & $\begin{array}{l}\text { Defore-tax revenue } \\
\text { Direct taxeo } \\
\text { otber current paymente } \\
\text { Interest } \\
\text { Dlvidende } \\
\text { Mot eaving }\end{array}$ & $\begin{array}{r}20.2 \\
3.3 \\
0.9 \\
6.5 \\
2.3 \\
5.2\end{array}$ & $\begin{array}{r}18.3 \\
3.6 \\
1.2 \\
9.9 \\
1.6 \\
2.0\end{array}$ & $\begin{array}{r}17.9 \\
1.0 \\
1.2 \\
9.2 \\
1.2 \\
2.3\end{array}$ & $\begin{array}{r}18.2 \\
4.4 \\
1.2 \\
0.8 \\
1.2 \\
2.6\end{array}$ & $\begin{array}{r}18.1 \\
4.2 \\
1.1 \\
8.5 \\
1.2 \\
3.1\end{array}$ & $\begin{array}{l}\cdots \\
\cdots \\
\cdots \\
\cdots \\
\cdots\end{array}$ \\
\hline & Het lending & -9.2 & -8.0 & -5.0 & -5.5 & -4.3 & $\cdots$ \\
\hline \multirow[t]{2}{*}{ Irence } & $\begin{array}{l}\text { Dofore-tax revenue } \\
\text { Direct taxe: } \\
\text { otbor current paymente } \\
\text { Intereat } \\
\text { Dividende } \\
\text { net eaving }\end{array}$ & $\begin{array}{l}\cdots \\
\cdots \\
\cdots \\
\cdots \\
\cdots\end{array}$ & $\begin{array}{r}10.2 \\
1.8 \\
2.8 \\
1.2 \\
2.0 \\
7.3\end{array}$ & $\begin{array}{r}19.3 \\
1.8 \\
3.2 \\
5.5 \\
2.4 \\
6.5\end{array}$ & $\begin{array}{r}19.7 \\
1.8 \\
3.1 \\
5.7 \\
2.4 \\
6.6\end{array}$ & $\begin{array}{r}20.7 \\
1.9 \\
3.0 \\
5.5 \\
2.5 \\
7.8\end{array}$ & $\begin{array}{r}21.1 \\
1.9 \\
3.0 \\
5.3 \\
2.7 \\
1.1\end{array}$ \\
\hline & Wot londing & . & -4.3 & -2.5 & -2.8 & -1.0 & -1.3 \\
\hline \multirow[t]{2}{*}{ Itely } & $\begin{array}{l}\text { Bofore-tax revenue } \\
\text { Direct taxes } \\
\text { otber current paymente } \\
\text { Intereat } \\
\text { Dividends } \\
\text { wot eaving }\end{array}$ & $\begin{array}{l}\cdots \\
\cdots \\
\cdots \\
\cdots\end{array}$ & $\begin{array}{r}6.9 \\
1.0 \\
3.1 \\
3.9 \\
0.1 \\
-1.3\end{array}$ & $\begin{array}{r}1.1 \\
1.5 \\
2.5 \\
5.8 \\
0.5 \\
-2.2\end{array}$ & $\begin{array}{r}1.4 \\
1.6 \\
2.4 \\
5.6 \\
0.6 \\
-1.8\end{array}$ & $\begin{array}{l}\cdots \\
\cdots \\
\cdots \\
\cdots \\
\cdots\end{array}$ & $\begin{array}{l}\ldots \\
\cdots \\
\cdots \\
\cdots \\
\cdots\end{array}$ \\
\hline & Not londing & $\cdots$ & -5.6 & -3.6 & -2.1 & $\cdots$ & $\cdots$ \\
\hline \multirow[t]{2}{*}{ Inlend } & $\begin{array}{l}\text { sofore-tax revenue } \\
\text { Direct taxeo } \\
\text { Otber eurrent pagmente } \\
\text { Interest } \\
\text { Dividoada } \\
\text { wet eaving }\end{array}$ & $\begin{array}{r}10.2 \\
2.0 \\
1.0 \\
3.5 \\
0.7 \\
3.0\end{array}$ & $\begin{array}{r}1.1 \\
1.4 \\
1.4 \\
3.2 \\
0.5 \\
-0.4\end{array}$ & $\begin{array}{r}9.9 \\
1.3 \\
1.6 \\
6.4 \\
0.7 \\
-0.1\end{array}$ & $\begin{array}{r}12.6 \\
2.3 \\
4.0 \\
6.5 \\
0.1 \\
-0.1\end{array}$ & $\begin{array}{r}11.6 \\
1.3 \\
3.6 \\
6.2 \\
0.9 \\
-0.3\end{array}$ & $\begin{array}{r}15.6 \\
1.4 \\
6.1 \\
6.1 \\
1.0 \\
1.1\end{array}$ \\
\hline & Wot lending & -3.6 & -6.3 & -3.4 & -3.3 & -3.0 & -3.0 \\
\hline \multirow[t]{2}{*}{ meden } & $\begin{array}{l}\text { Dofore-tax rovonue } \\
\text { Direct texee } \\
\text { Otber current paymente } \\
\text { Interest } \\
\text { DIvidonds } \\
\text { not eaving }\end{array}$ & $\begin{array}{l}\because \\
\cdots \\
\cdots \\
\cdots\end{array}$ & $\begin{array}{r}7.0 \\
1.0 \\
1.7 \\
3.6 \\
0.9 \\
-0.2\end{array}$ & $\begin{array}{l}9.7 \\
1.3 \\
1.8 \\
1.7 \\
1.2 \\
0.8\end{array}$ & $\begin{array}{r}21.3 \\
1.5 \\
2.0 \\
1.5 \\
1.3 \\
2.2\end{array}$ & $\begin{array}{r}11.2 \\
1.2 \\
2.1 \\
5.0 \\
1.5 \\
1.4\end{array}$ & $\begin{array}{l}\ddot{*} \\
\ddot{*} \\
\ddot{*}\end{array}$ \\
\hline & Wot londing & $\cdots$ & -4.7 & -1.9 & -2.5 & -2.6 & $\cdots$ \\
\hline \multirow[t]{2}{*}{ anctend4a } & $\begin{array}{l}\text { Dofore-tax roveaus } \\
\text { Direct taxeo } \\
\text { othex curront paymonts } \\
\text { Intereat } \\
\text { Dividonds } \\
\text { not eaving }\end{array}$ & $\begin{array}{l}\cdots \\
\cdots \\
\cdots \\
\cdots\end{array}$ & $\begin{array}{l}7.6 \\
2.9 \\
0.8 \\
1.8 \\
1.6 \\
0.5\end{array}$ & $\begin{array}{r}5.1 \\
2.2 \\
1.1 \\
2.1 \\
1.1 \\
-2.2\end{array}$ & $\begin{array}{r}6.1 \\
2.1 \\
1.2 \\
3.1 \\
1.0 \\
-1.3\end{array}$ & $\begin{array}{r}3.0 \\
2.1 \\
1.2 \\
3.0 \\
1.0 \\
-2.2\end{array}$ & $\begin{array}{l}\ddot{ } \\
\ddot{*} \\
\ddot{*} \\
\ddot{-}\end{array}$ \\
\hline & Wot londing & $\cdots$ & -3.7 & -6.0 & -5.6 & -3.4 & $\cdots$ \\
\hline
\end{tabular}

a) Ior the nop-financtel corporate eector.

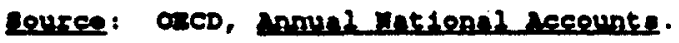


Table 8a

DEMOGRAPHIC AND SOCIAL FACTORS INFLUENCING HOUSEHOLD SAVING

\begin{tabular}{|c|c|c|c|c|c|}
\hline & $\begin{array}{l}\text { Old age } \\
\text { dependency } \\
\text { ratio }\end{array}$ & $\begin{array}{l}\text { Young age } \\
\text { dependency } \\
\text { ratio }\end{array}$ & $\begin{array}{c}\text { Participation } \\
\text { rate: }>65\end{array}$ & $\begin{array}{l}\text { Population } \\
\text { growth }\end{array}$ & $\begin{array}{l}\text { Participation } \\
\text { rate: women }\end{array}$ \\
\hline $1962 \cdot 1970$ & & & . & & \\
\hline $\begin{array}{l}\text { United States } \\
\text { Japan } \\
\text { Germany } \\
\text { United Kingdom } \\
\text { Canada } \\
\text { Australia } \\
\text { Finland }\end{array}$ & $\begin{array}{r}15.8 \\
9.5 \\
18.9 \\
19.3 \\
13.0 \\
13.6 \\
12.7\end{array}$ & $\begin{array}{l}49.5 \\
37.7 \\
35.0 \\
36.8 \\
54.6 \\
47.4 \\
41.2\end{array}$ & $\begin{array}{r}16.7 \\
35.6 \\
12.4 \\
12.6 \\
14.3 \\
12.1 \\
8.8\end{array}$ & $\begin{array}{l}1.2 \\
1.1 \\
0.8 \\
0.5 \\
1.7 \\
1.9 \\
0.3\end{array}$ & $\begin{array}{r}45.5 \\
56.4 \\
48.5 \\
49.2 \\
\ldots \\
61.9\end{array}$ \\
\hline \multicolumn{6}{|l|}{$1271-1280$} \\
\hline $\begin{array}{l}\text { United States } \\
\text { Japan } \\
\text { Germany } \\
\text { France } \\
\text { United Kingdom } \\
\text { Canada } \\
\text { Australia } \\
\text { Finland } \\
\text { Netherlands } \\
\text { Norway } \\
\text { Sweden }\end{array}$ & $\begin{array}{l}16.4 \\
11.8 \\
22.6 \\
21.5 \\
22.4 \\
13.4 \\
13.9 \\
16.0 \\
16.9 \\
22.7 \\
23.6\end{array}$ & $\begin{array}{l}38.8 \\
35.4 \\
32.5 \\
37.7 \\
36.3 \\
40.3 \\
42.4 \\
32.7 \\
38.8 \\
36.7 \\
31.8\end{array}$ & $\begin{array}{r}13.2 \\
28.0 \\
6.8 \\
8.6 \\
8.6 \\
9.4 \\
8.9 \\
10.9 \\
4.2 \\
15.5 \\
7.5\end{array}$ & $\begin{array}{l}1.0 \\
1.2 \\
0.0 \\
0.6 \\
0.1 \\
1.2 \\
1.3 \\
0.4 \\
0.8 \\
0.4 \\
0.3\end{array}$ & $\begin{array}{l}54.1 \\
53.5 \\
49.4 \\
51.7 \\
55.0 \\
50.5 \\
49.3 \\
66.2 \\
58.9 \\
67.5\end{array}$ \\
\hline \multicolumn{6}{|l|}{$1981 \cdot 1986$} \\
\hline $\begin{array}{l}\text { United States } \\
\text { Japan } \\
\text { Germany } \\
\text { France } \\
\text { United Kingdom } \\
\text { Italy } \\
\text { Canada } \\
\text { Australia } \\
\text { Finland } \\
\text { Netherlands } \\
\text { Norway } \\
\text { Spain } \\
\text { Sweden }\end{array}$ & $\begin{array}{l}17.7 \\
14.5 \\
21.7 \\
20.2 \\
23.1 \\
19.1 \\
14.9 \\
15.3 \\
18.2 \\
17.6 \\
24.2 \\
18.3 \\
26.3\end{array}$ & $\begin{array}{l}33.1 \\
32.9 \\
23.2 \\
33.0 \\
30.2 \\
27.3 \\
32.3 \\
36.6 \\
28.8 \\
30.1 \\
32.4 \\
37.4 \\
28.7\end{array}$ & $\begin{array}{r}10.8 \\
25.1 \\
3.6 \\
3.6 \\
5.3 \\
5.8 \\
7.5 \\
5.1 \\
5.0 \\
1.8 \\
12.6 \\
4.9 \\
4.4\end{array}$ & $\begin{array}{r}1.0 \\
0.6 \\
-0.2 \\
0.4 \\
0.1 \\
0.3 \\
0.8 \\
1.4 \\
0.5 \\
0.5 \\
0.3 \\
0.5 \\
0.1\end{array}$ & $\begin{array}{l}62.6 \\
56.7 \\
50.2 \\
54.7 \\
58.8 \\
40.4 \\
61.1 \\
53.3 \\
72.7 \\
40.0 \\
66.5 \\
32.8 \\
76.7\end{array}$ \\
\hline
\end{tabular}

Source: OECD, Labour Force Statistics. 


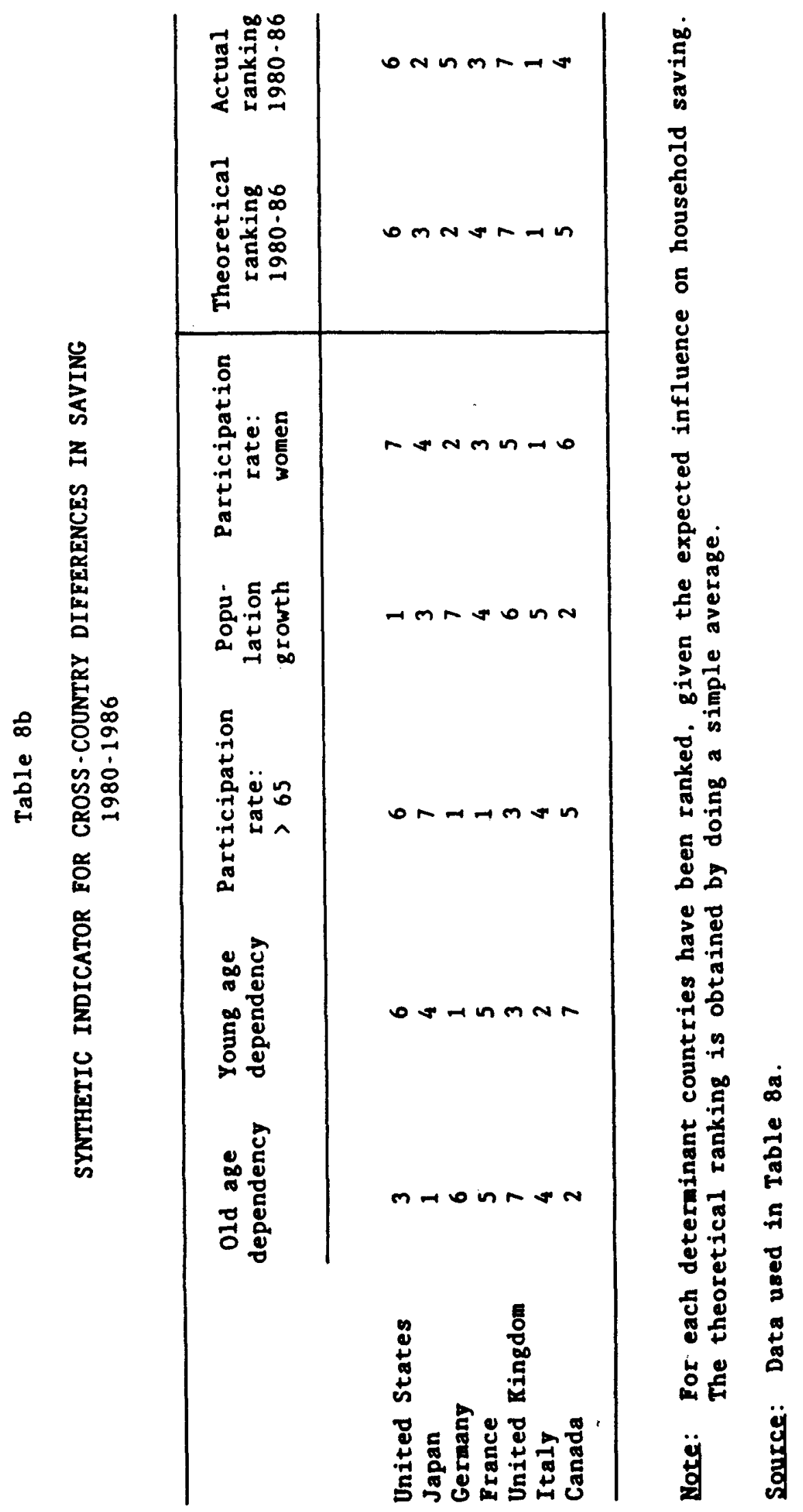


Table 9

INCOME DISTRIBUTION

(per cent of gross disposable income)

\begin{tabular}{|c|c|c|c|c|}
\hline & & $\begin{array}{l}\text { Net property } \\
\text { income }\end{array}$ & $\begin{array}{c}\text { Net interest } \\
\text { payments }\end{array}$ & Dividends \\
\hline 1962-1970: & $\begin{array}{l}\text { United States } \\
\text { Japan } \\
\text { Germany } \\
\text { United Kingdom } \\
\text { Canada } \\
\text { Australia } \\
\text { Finland }\end{array}$ & $\begin{array}{r}12.0 \\
6.2 \\
30.9 \\
9.7 \\
6.6 \\
7.4 \\
0.6\end{array}$ & $\begin{array}{l}5.1 \\
3.7 \\
2.7 \\
9.7 \\
4.9 \\
4.7 \\
0.2\end{array}$ & $\begin{array}{l}3.5 \\
2.2 \\
0.5 \\
1.7 \\
1.7 \\
2.7 \\
0.4\end{array}$ \\
\hline 1271-1980: & $\begin{array}{l}\text { United States } \\
\text { Japan } \\
\text { Germany } \\
\text { France } \\
\text { United Kingdom } \\
\text { Italy } \\
\text { Canada } \\
\text { Australia } \\
\text { Finland } \\
\text { Netherlands (a) } \\
\text { Norway } \\
\text { Sweden }\end{array}$ & $\begin{array}{r}11.2 \\
7.1 \\
31.2 \\
3.5 \\
5.5 \\
2.4 \\
8.7 \\
7.9 \\
0.4 \\
25.7 \\
.0 .8 \\
-0.7\end{array}$ & $\begin{array}{l}7.4 \\
4.7 \\
4.9 \\
1.1 \\
5.5 \\
2.1 \\
6.7 \\
6.5 \\
.0 .4 \\
1.5 \\
-1.1 \\
.2 .0\end{array}$ & $\begin{array}{r}2.6 \\
1.9 \\
0.3 \\
2.4 \\
\ldots .2 \\
2.0 \\
1.4 \\
0.3 \\
19.7 \\
0.9\end{array}$ \\
\hline 1981-1987: & $\begin{array}{l}\text { United States } \\
\text { Japan } \\
\text { Germany } \\
\text { France } \\
\text { United Kingdom } \\
\text { Italy (b) } \\
\text { Canada } \\
\text { Australia } \\
\text { Finland } \\
\text { Netherlands } \\
\text { Norway } \\
\text { Spain } \\
\text { Sweden }\end{array}$ & $\begin{array}{r}15.5 \\
8.4 \\
33.3 \\
4.3 \\
4.6 \\
6.0 \\
14.1 \\
11.7 \\
0.3 \\
27.4 \\
-2.4 \\
3.7 \\
-1.4\end{array}$ & $\begin{array}{r}12.4 \\
5.9 \\
7.1 \\
1.9 \\
4.6 \\
5.7 \\
11.6 \\
10.9 \\
-0.9 \\
4.7 \\
-3.1 \\
2.6 \\
-3.1\end{array}$ & $\begin{array}{r}2.7 \\
1.9 \\
0.3 \\
2.3 \\
0.3 \\
0.3 \\
2.5 \\
0.8 \\
0.4 \\
22.8 \\
0.7 \\
1.1 \\
1.0\end{array}$ \\
\hline
\end{tabular}

a) 1977 to 1980 .

b) 1981 to 1985 .

Source: OECD, Annual National Accounts. 
Table 10

TAXATION OF HOUSING

(1987 tax rules)

\begin{tabular}{|c|c|c|c|}
\hline & \multicolumn{2}{|c|}{ Deductibility of interest } & \multirow{2}{*}{$\begin{array}{l}\text { Taxation of } \\
\text { imputed rent }\end{array}$} \\
\hline & $\begin{array}{l}\text { Principal } \\
\text { residence }\end{array}$ & $\begin{array}{l}\text { Secondary } \\
\text { residence (a) }\end{array}$ & \\
\hline $\begin{array}{l}\text { United States } \\
\text { Japan } \\
\text { Germany } \\
\text { France } \\
\text { United Ringdom } \\
\text { Italy } \\
\text { Canada }\end{array}$ & $\begin{array}{l}\text { TA } \\
T C(L) \\
T A \text { (b) } \\
T C \\
T A(L) \\
T A(L) \\
\text { No }\end{array}$ & $\begin{array}{l}\text { TA } \\
\text { No } \\
\text { No } \\
\text { No } \\
\text { No } \\
\text { TA (L) } \\
\text { No }\end{array}$ & $\begin{array}{l}\text { No } \\
\text { No } \\
\text { Yes } \\
\text { No } \\
\text { No } \\
\text { Yes } \\
\text { No }\end{array}$ \\
\hline $\begin{array}{l}\text { Austria } \\
\text { Belgium } \\
\text { Denmark } \\
\text { Finland } \\
\text { Greece } \\
\text { Ireland } \\
\text { Luxembourg } \\
\text { Netherlands } \\
\text { Norway } \\
\text { Portugal } \\
\text { Spain } \\
\text { Sweden } \\
\text { Switzerland } \\
\text { Turkey }\end{array}$ & $\begin{array}{l}T A(L) \\
T A(L) \\
T A \\
T A(L) \\
T A(L) \\
T A(L) \\
T A(L) \\
T A \\
T A \\
T A(L) \\
\text { TA(L) } \\
\text { TA } \\
\text { TA } \\
\text { No }\end{array}$ & $\begin{array}{l}\text { No } \\
\text { TA (L) } \\
\text { TA } \\
\text { TA (L) } \\
\text { No } \\
\text { No } \\
\text { TA }(L) \\
\text { TA } \\
\text { TA } \\
\text { TA(L) } \\
\text { TA (L) } \\
\text { TA } \\
\text { No } \\
\text { No }\end{array}$ & $\begin{array}{l}\text { No } \\
\text { Yes } \\
\text { Yes } \\
\text { Yes } \\
\text { Yes } \\
\text { No } \\
\text { Yes } \\
\text { Yes } \\
\text { Yes } \\
\text { Yes } \\
\text { Yes } \\
\text { Yes } \\
\text { Yes } \\
\text { No }\end{array}$ \\
\hline $\begin{array}{l}\text { Australia } \\
\text { New Zealand }\end{array}$ & $\begin{array}{l}\operatorname{TC}(L) \\
\text { No }\end{array}$ & $\begin{array}{l}\text { No } \\
\text { No }\end{array}$ & $\begin{array}{l}\text { No } \\
\text { No }\end{array}$ \\
\hline
\end{tabular}

a) 1985 tax rules.

b) Abolished in 1988 .

Note: $T C=$ tax credit: IA $=$ tax allowance: $L=$ limited deductibility: No = no tax relief.

Source: OECD information. 
zable 11

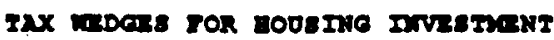

(Porcentage pointe, ueing 1905 tax paramere)

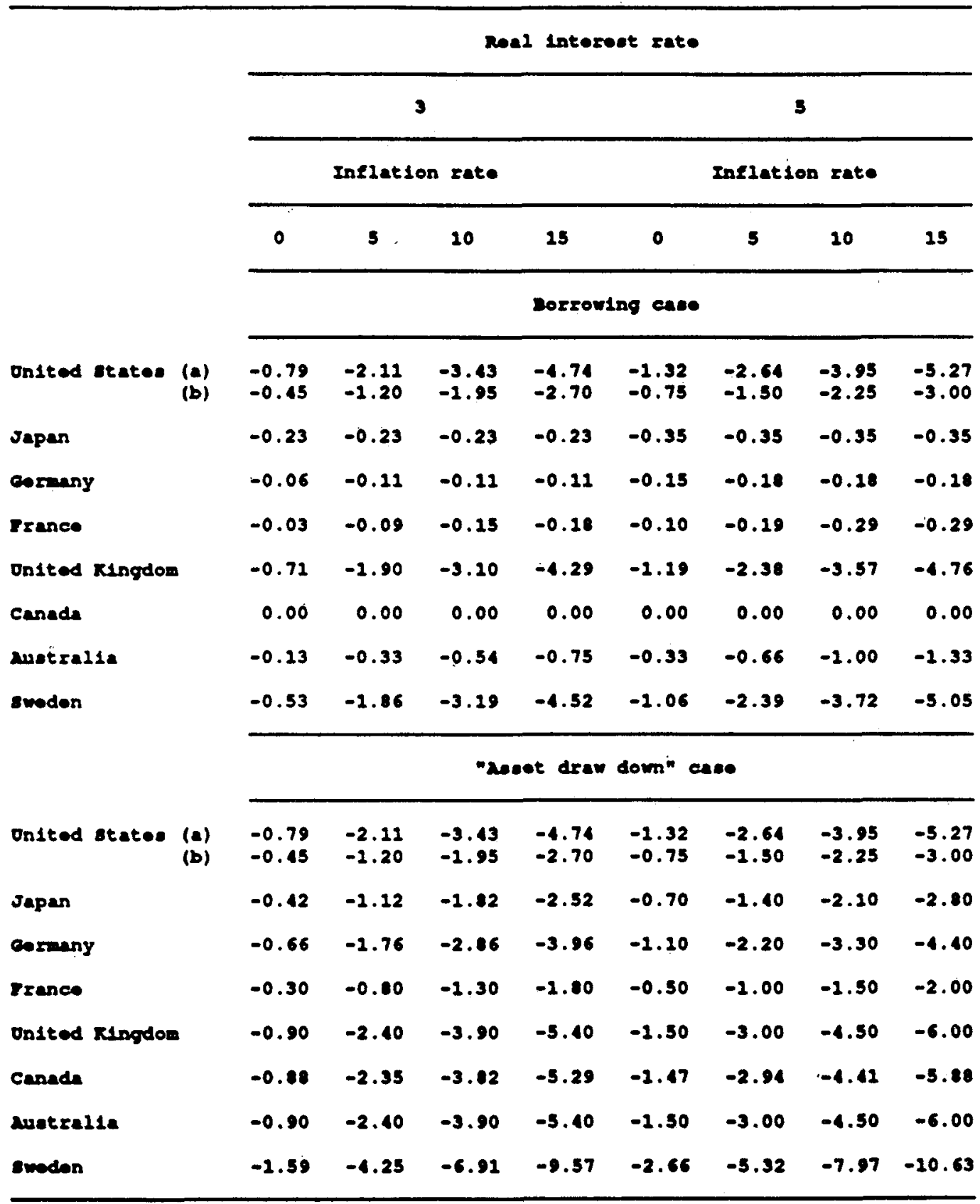

a) 01d.

b) now.

Yote: The celoulatione take Into eccount:

a) the doduct lbility of lnterost paymonte and oventual 11nite,

b) the avallability of tax crodite and oubaldised loane,

c) the taxation of lpputed Incom fron ommer-occupled bousing.

tho "nent drax down" case rasore to flnaneing by tho ifquidation of Elnancial enoete. In this case tho opportunity coot of bousing lnvestiont dopende on the meginal tar rate on lnteront lneom.

Lourea: rukno and ranasak1 (1907). 
Table 12

TAXATION OF CONSURER PURCHASES

(1985 tax rules)

\begin{tabular}{|c|c|c|}
\hline & $\begin{array}{l}\text { Deductibility of } \\
\text { consumer credit } \\
\text { interest }\end{array}$ & $\begin{array}{l}\text { Tax-favoured mortgage } \\
\text { credit is, de facto, used for } \\
\text { consumer purchases }\end{array}$ \\
\hline $\begin{array}{l}\text { United States } \\
\text { Japan } \\
\text { Germany } \\
\text { France } \\
\text { United Bingdom } \\
\text { Italy } \\
\text { Canada }\end{array}$ & $\begin{array}{l}\text { TA }(a) \\
\text { No } \\
\text { No } \\
\text { No } \\
\text { No } \\
\text { No } \\
\text { No }\end{array}$ & $\begin{array}{l}\text { Yes } \\
\text { No } \\
\text { No } \\
\text { No } \\
\text { Yes } \\
\text { No } \\
\text { No }\end{array}$ \\
\hline $\begin{array}{l}\text { Austria } \\
\text { Belgium } \\
\text { Denmark } \\
\text { Finland } \\
\text { Greece } \\
\text { Ireland } \\
\text { Luxembourg } \\
\text { Netherlands } \\
\text { Norway } \\
\text { Portugal } \\
\text { Spain } \\
\text { Sweden } \\
\text { Switzerland } \\
\text { Turkey }\end{array}$ & $\begin{array}{l}\text { No } \\
\text { No } \\
\text { TA } \\
\text { TA (L) } \\
\text { No } \\
\text { No } \\
\text { TA } \\
\text { TA } \\
\text { TA } \\
\text { No } \\
\text { No } \\
\text { TA } \\
\text { TA } \\
\text { No }\end{array}$ & $\begin{array}{l}\text { No } \\
\text { No } \\
\text { Yes } \\
\text { Yes } \\
\ldots \\
\ldots \\
\text { No } \\
\text { Yes } \\
\ldots \\
\text { Yes } \\
\text { Yes } \\
\text { No }\end{array}$ \\
\hline $\begin{array}{l}\text { Australia } \\
\text { New Zealand }\end{array}$ & $\begin{array}{l}\text { No } \\
\text { No }\end{array}$ & $\begin{array}{l}\text { No } \\
\text { No }\end{array}$ \\
\hline
\end{tabular}

a) Phased out under 1986 Tax Reform Act.

Note: $\mathrm{TA}=\operatorname{tax}$ allowance: $\mathrm{L}=$ limited deductibility: No $=$ no tax relief.

Source: OECD information. 
Chart A

TRENDS IN NATIONAL SAVING AND INVESTMENT RATES

(per cent of GNP)

gross saving
$\ldots \ldots$ gross investment

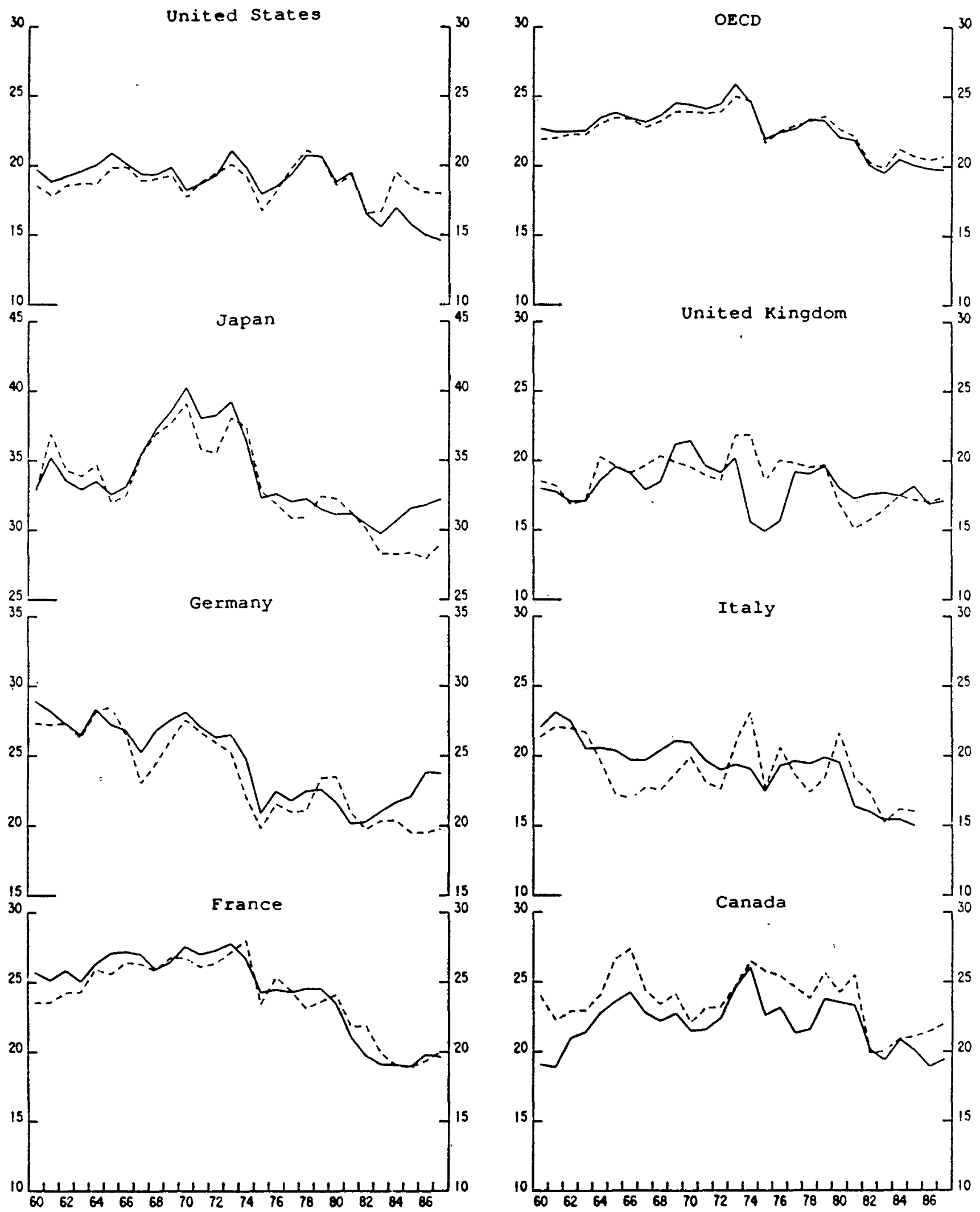


Chart $A$ continued

gross saving
$\ldots \ldots$ gross investment
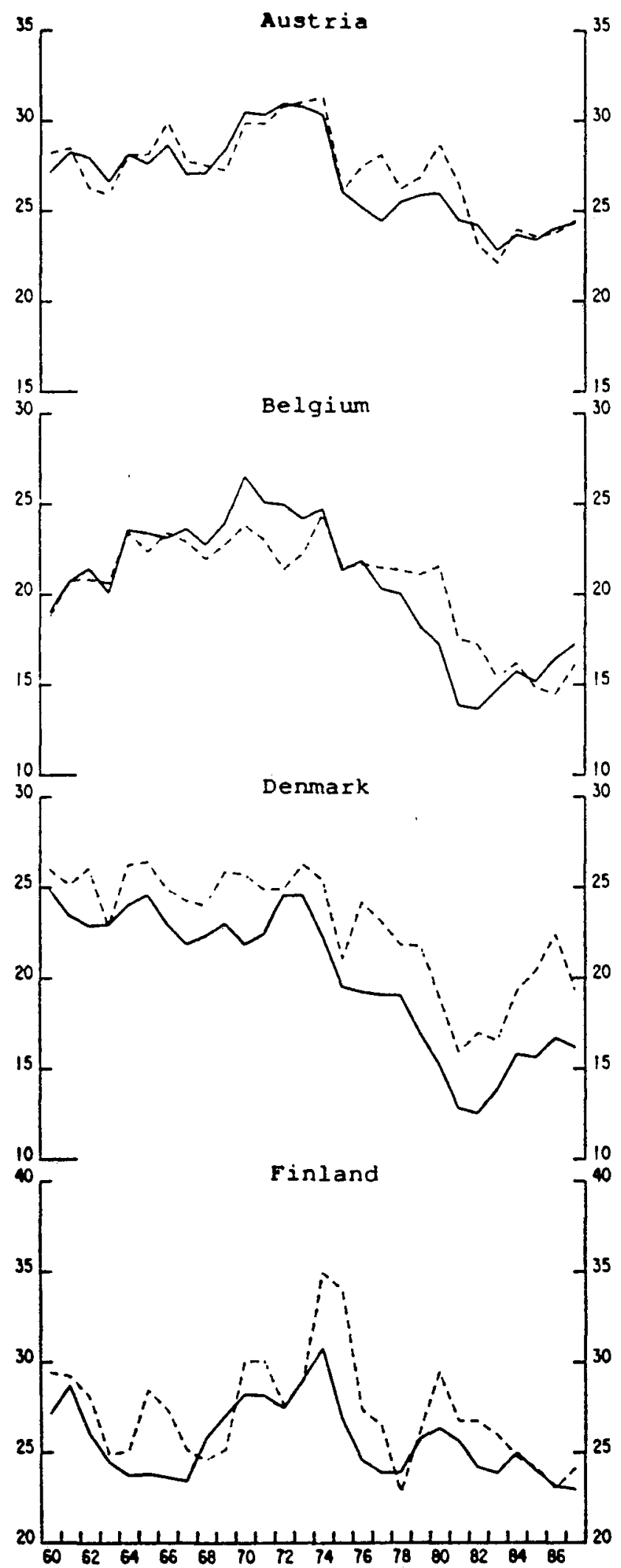
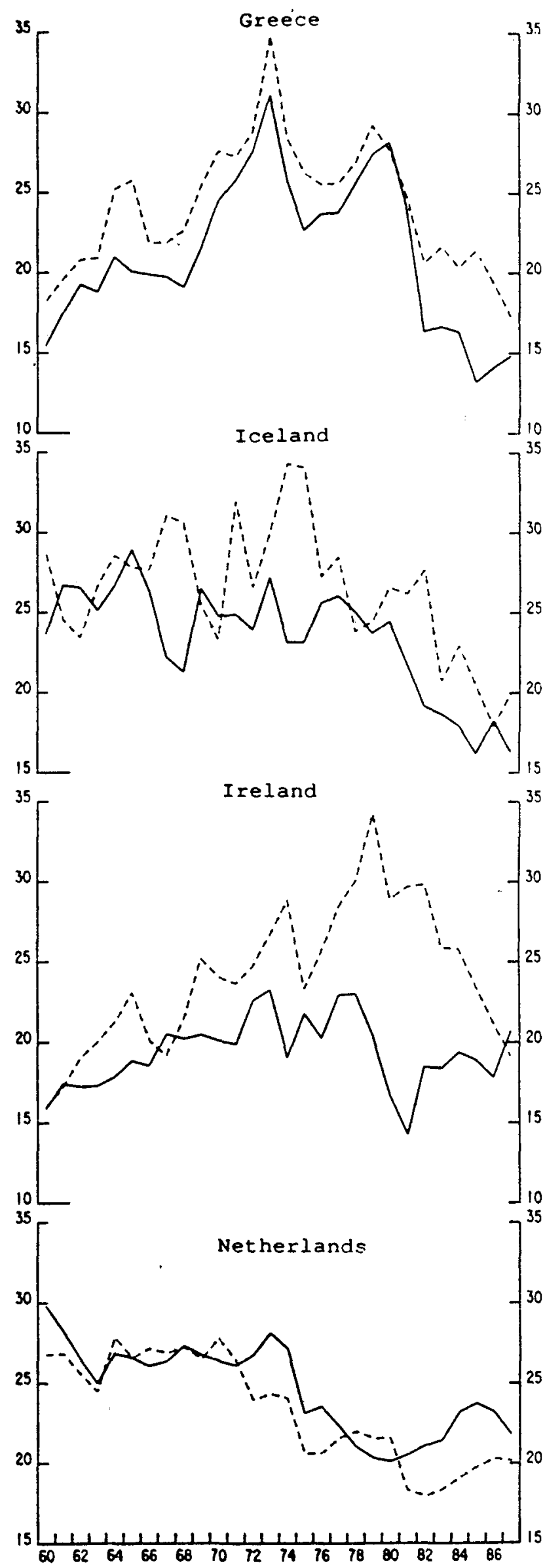
Chart A continued

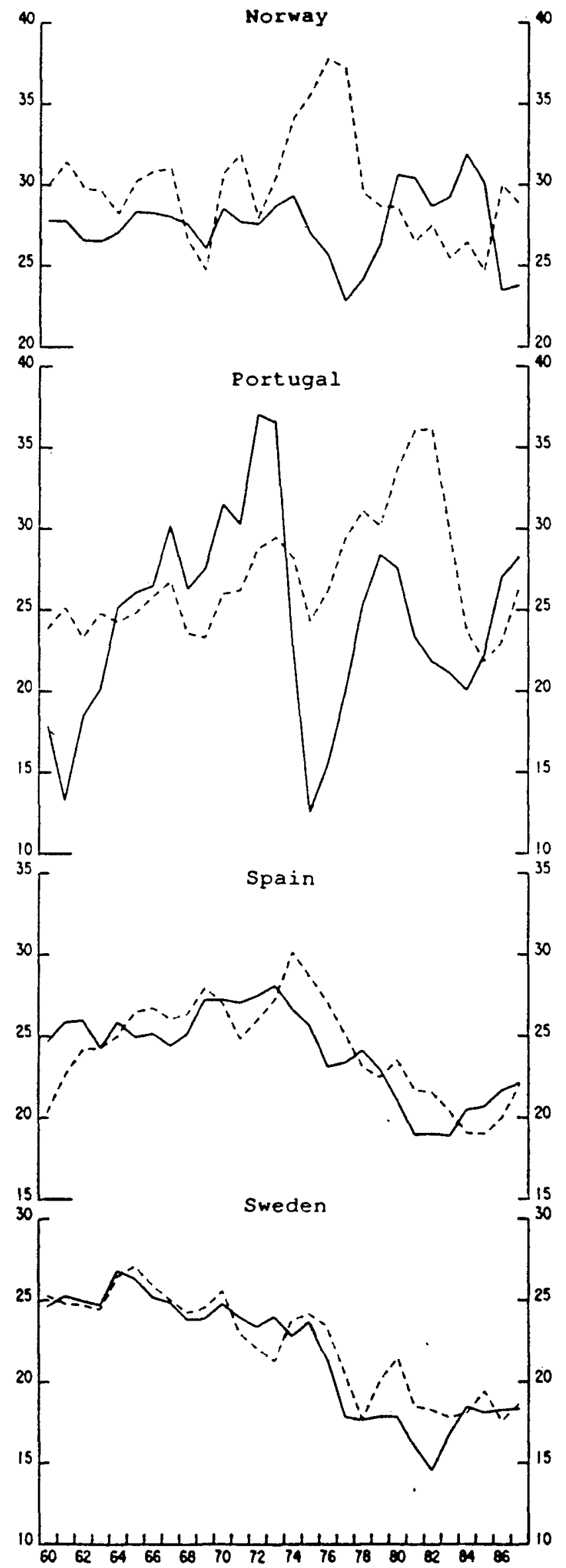

gross saving
$\ldots \ldots$
gross investment
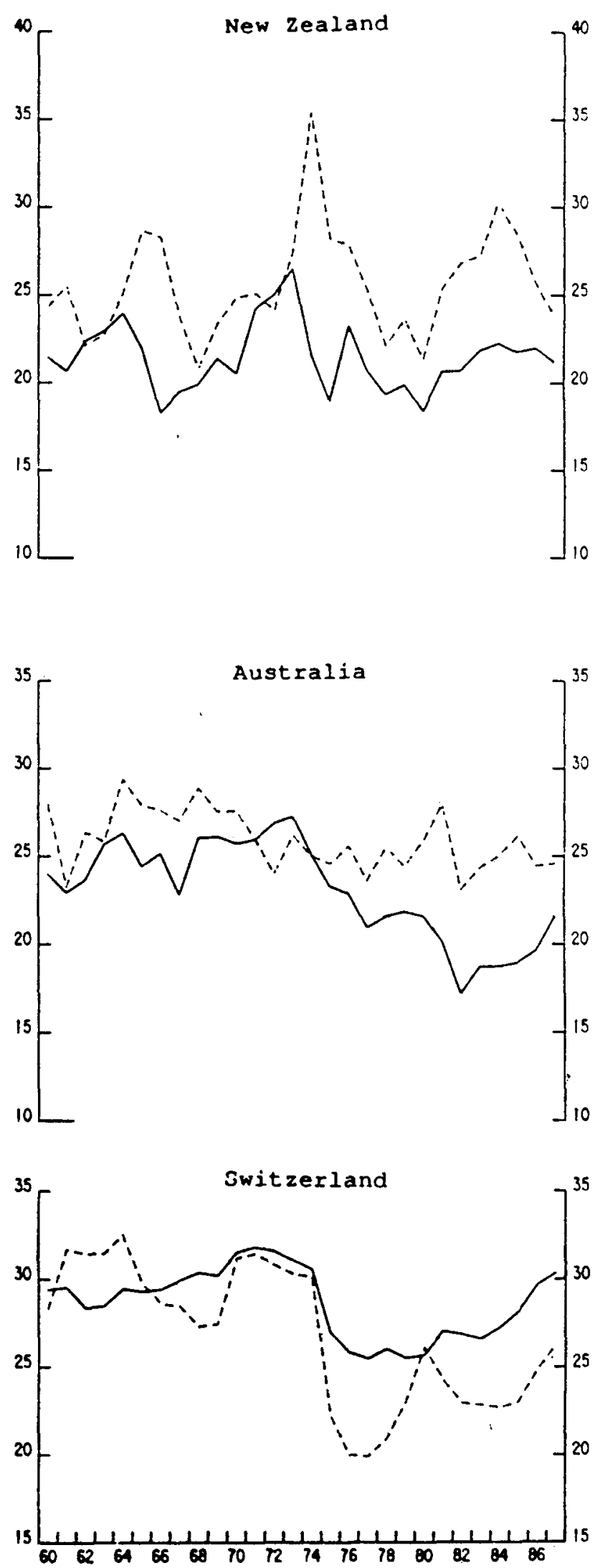

Source: OECD. Annual Netional Accounts. 
Chart 8

\section{REAL GROSS TIXED INVISTMEENT \\ (per cent of GNP/GDP)}

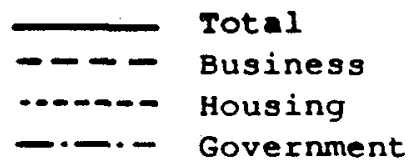

France

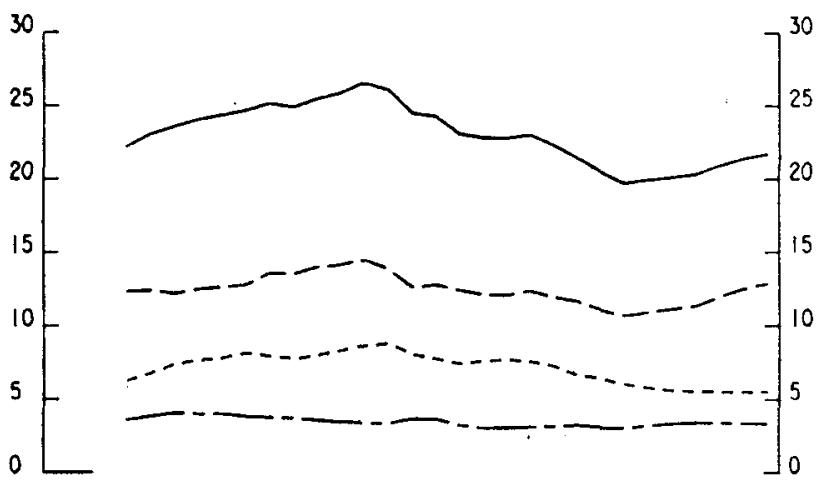

United Kingdom
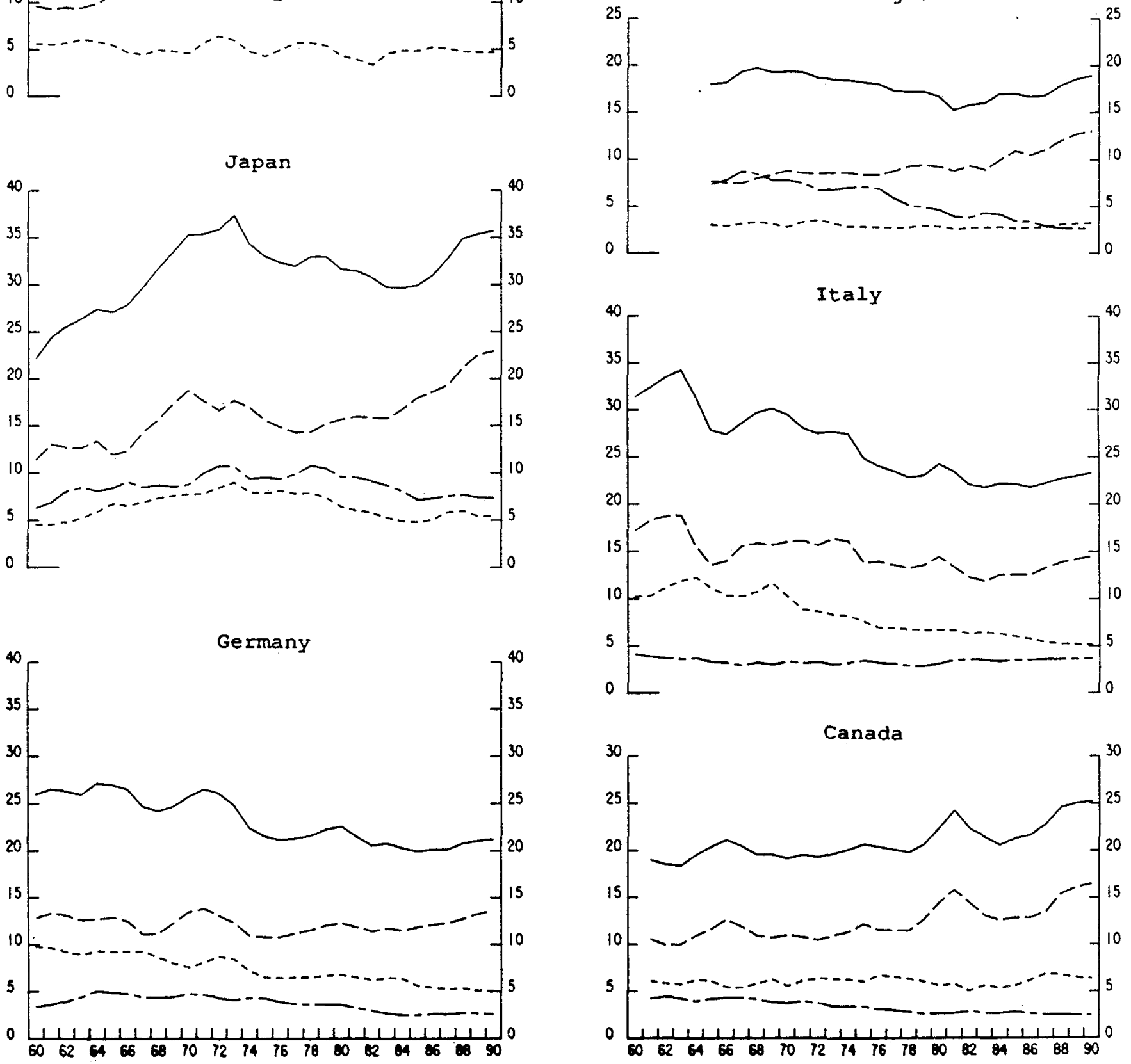

Source: OICD, Icononic Outilook 44. 
Chart C

\section{EXTERNAL ASSETS AND LIABILITIES}

(per cent of GDP)

Miteo sTATES

\section{MPAN}

ortom assers

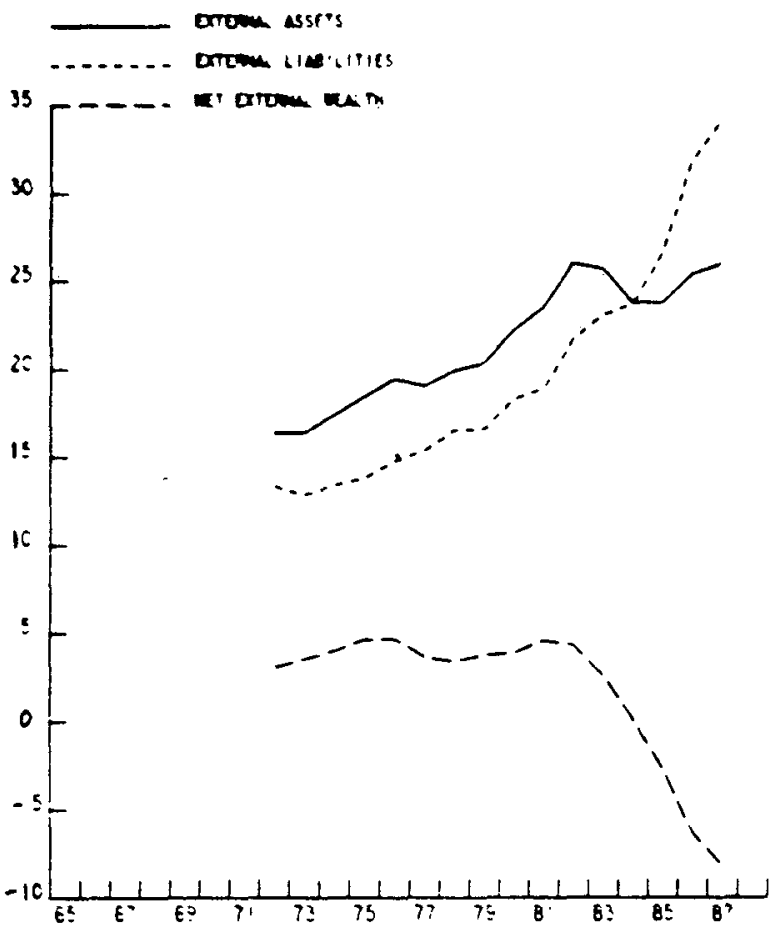

GE PU:S-

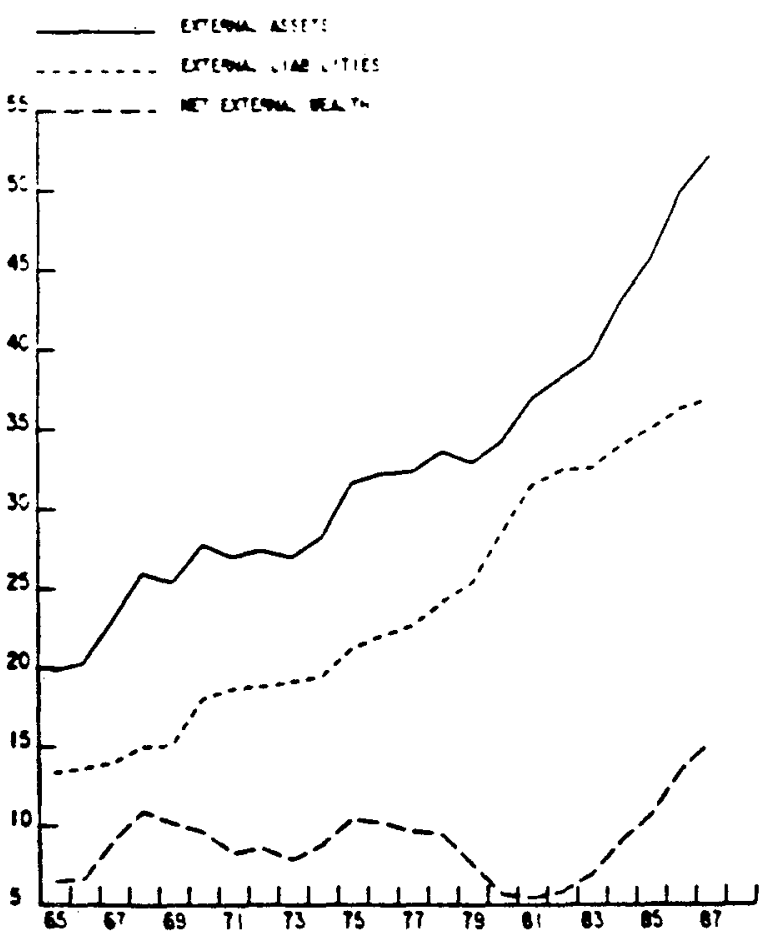

Orremen assers

ontome tivibitiles

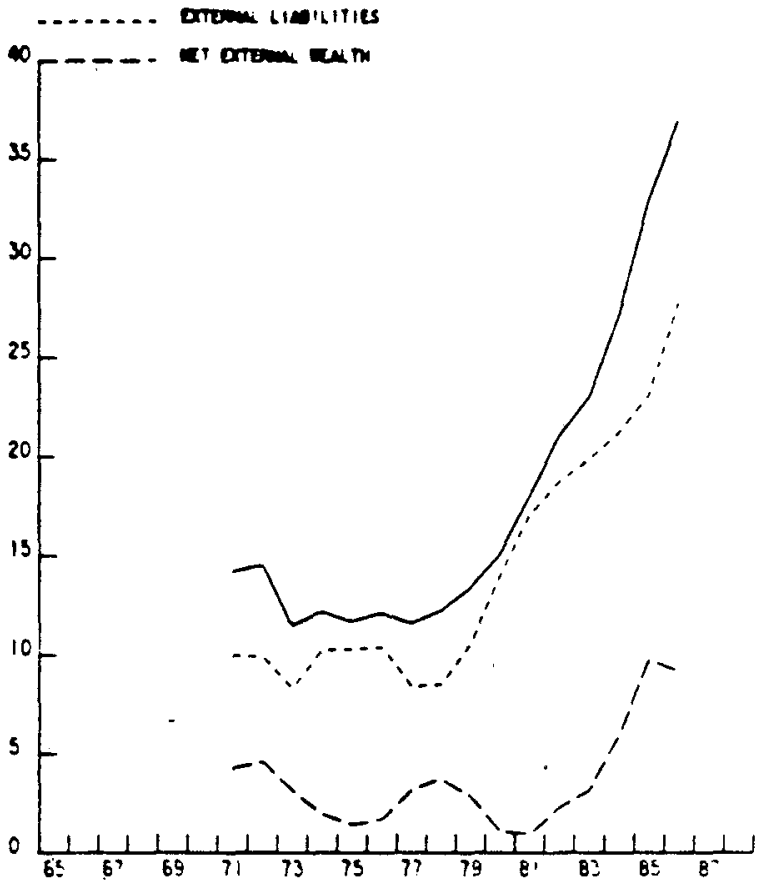

UNITED KINEDON

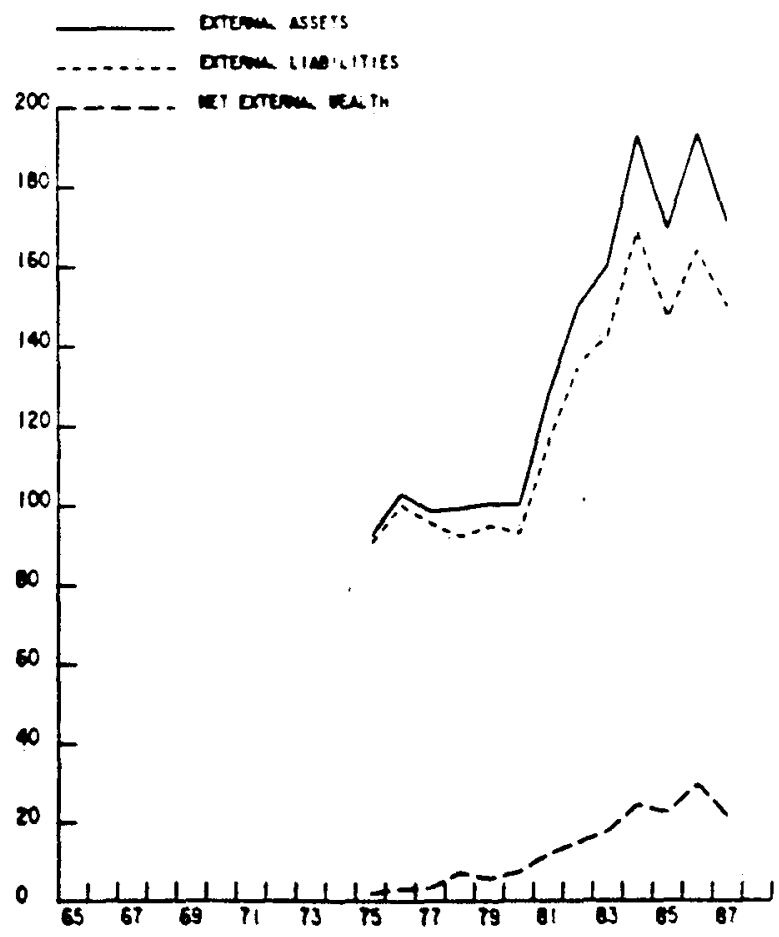

Source: U.S. Department of Commerce, Bank of Japan, U.R. Central Statistical Office. Deutsche Bundesbank. 
Chart D

\section{GROSS SAVIMG RATIOS: RECINT TRENDS AND OUTLOOR (per cent of GNP/GDP)}
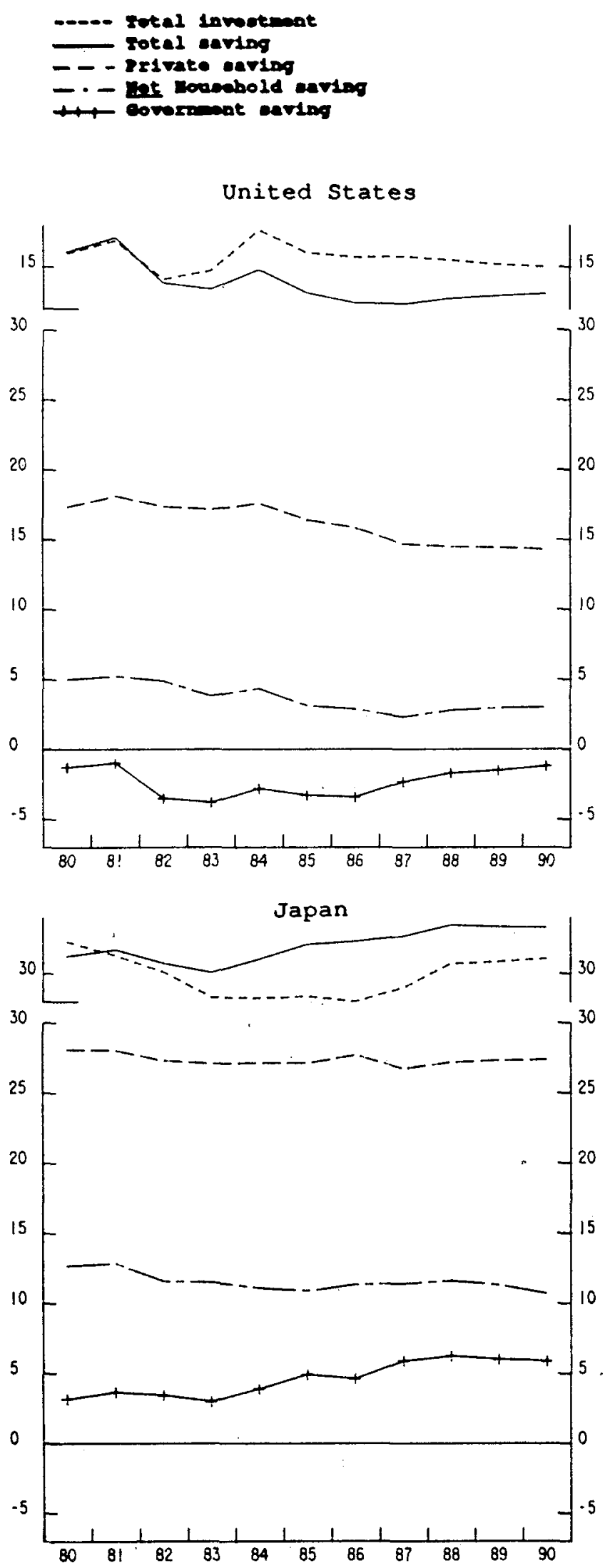

Germany
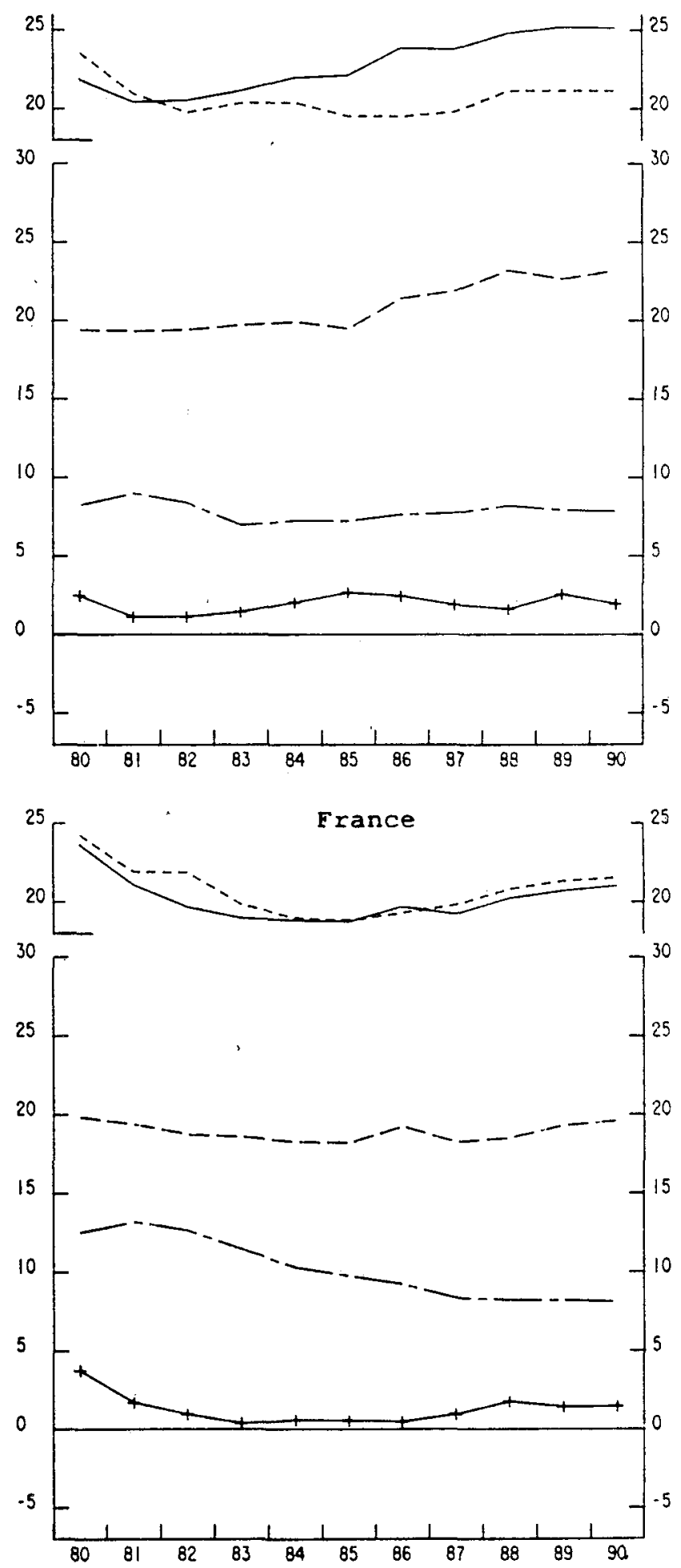


\section{Chart D continued}

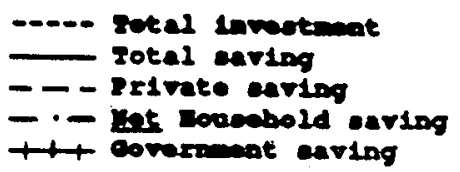

United Kingdom
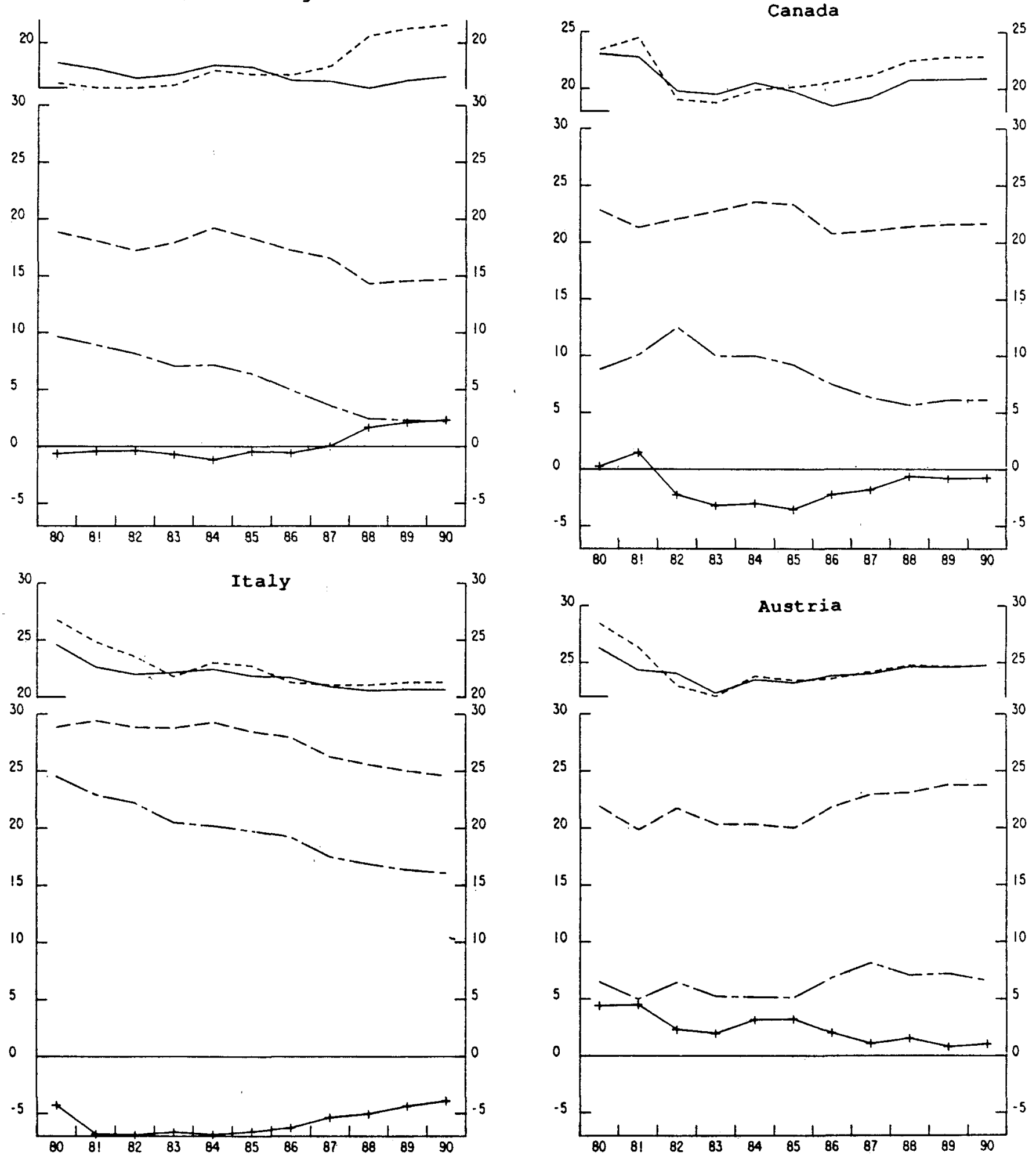


\section{Chart D continued}

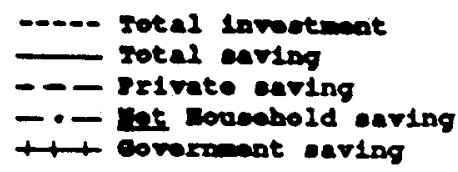

Denmark
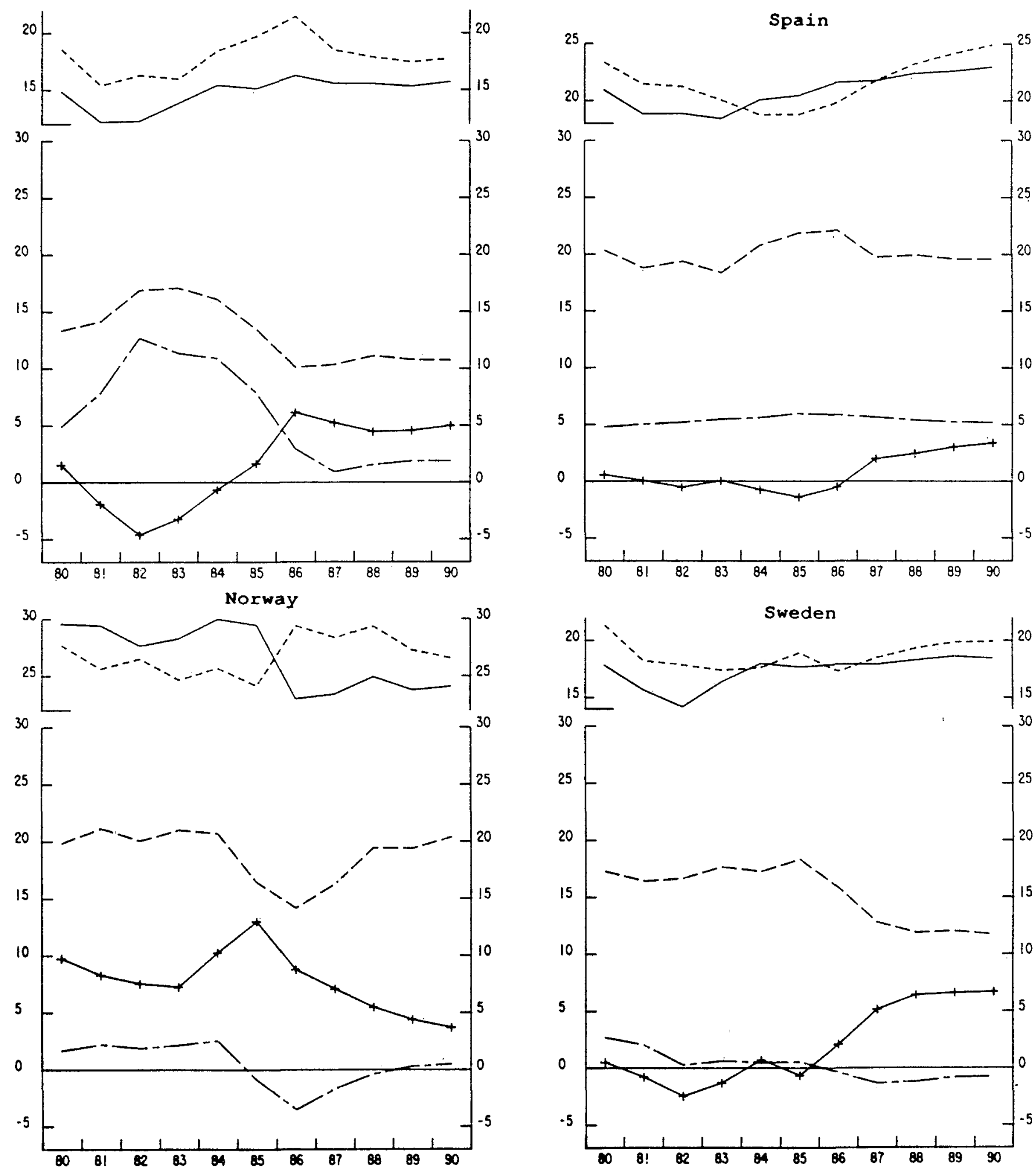

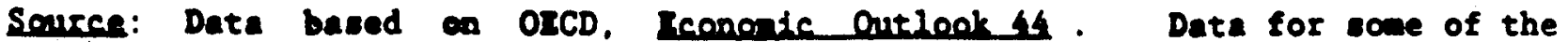
countries refer to national definitions and may not be atrictly comparable to those in the other tables and diagrams. 
Chart E

WEALTH/GNP RATIOS

aen con $\propto$

WITED STATES

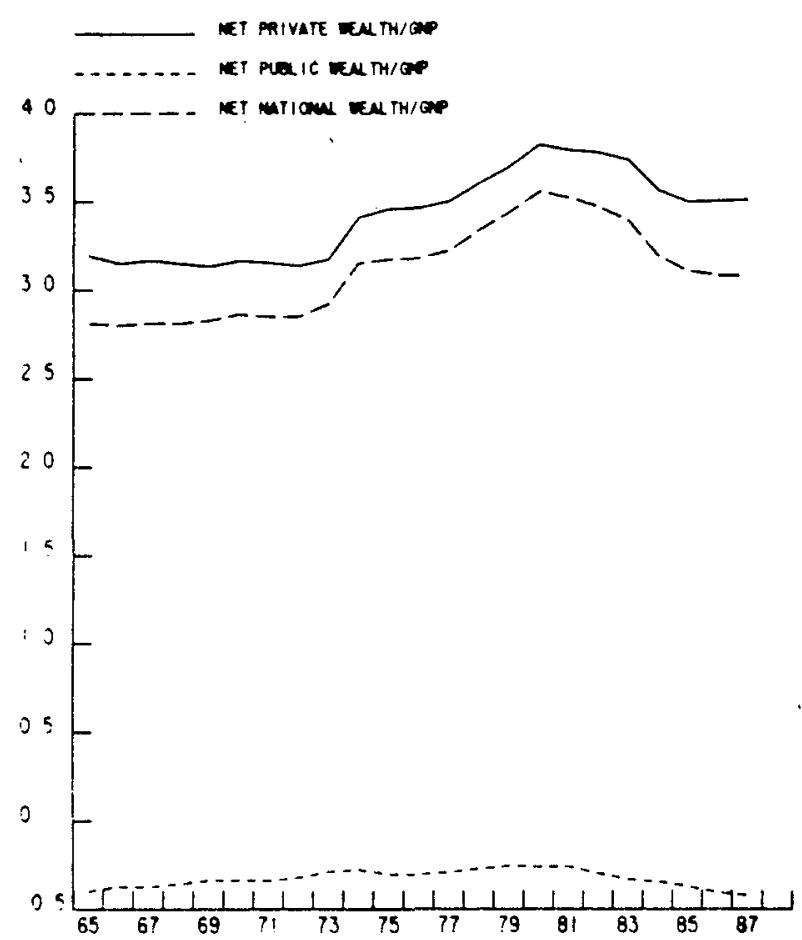

CANAOA

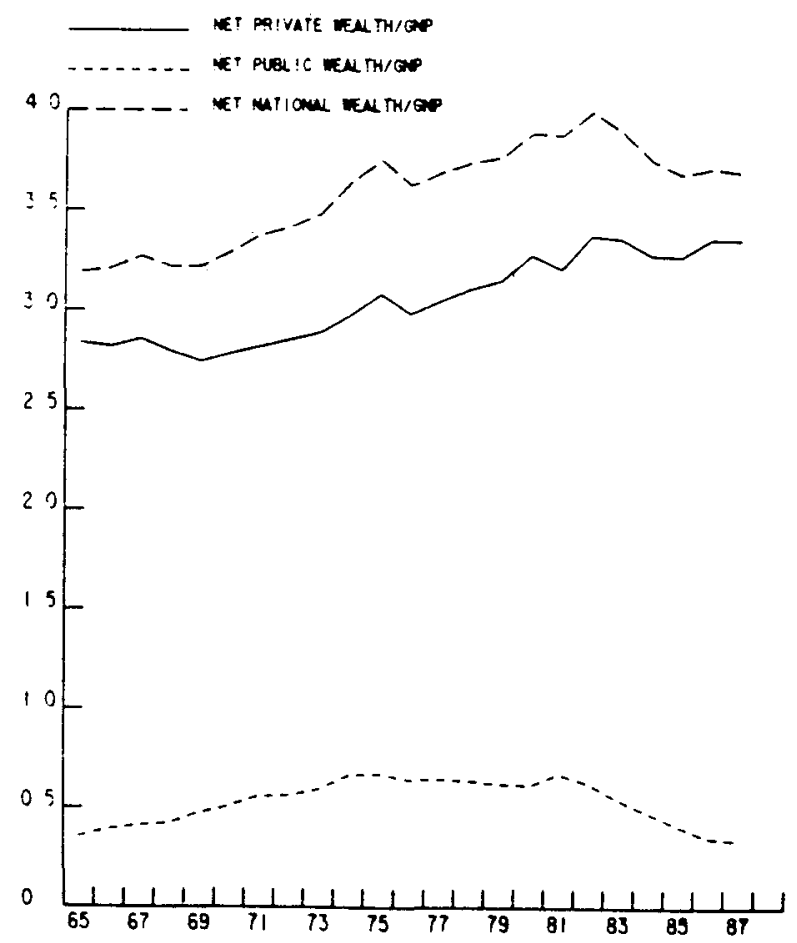

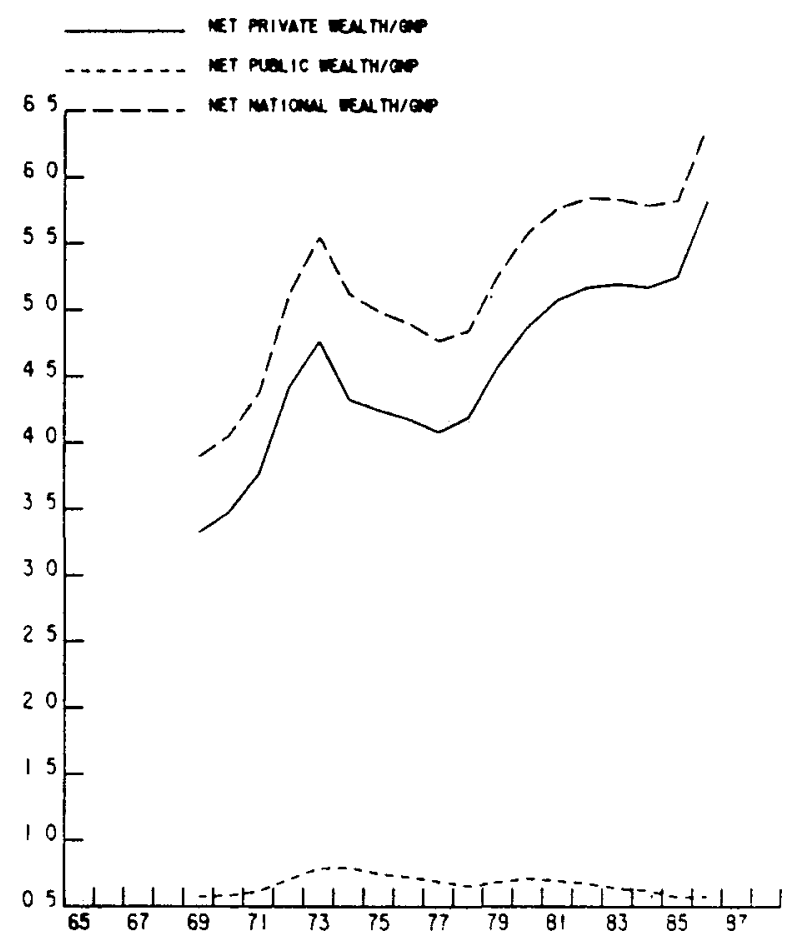

UNI TED KINGDOM

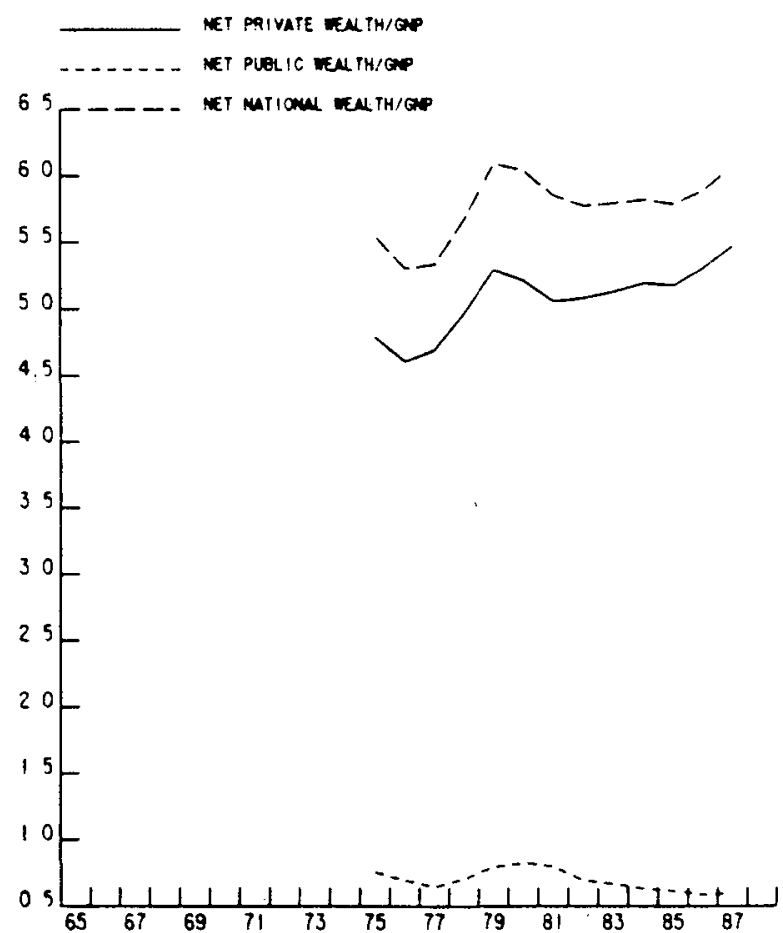

Note: For the public sector of the United States, financial wealth only.

Source: U.S. Federal Reserve, U.K. Central Statistical Cffice, Japanese Economic Flanning Agency, Statistics Canada. 
Chart E

NET AND GROSS HOUSEHOLD SAVING RATIOS

Net saving ratio

- - Gross saving ratio
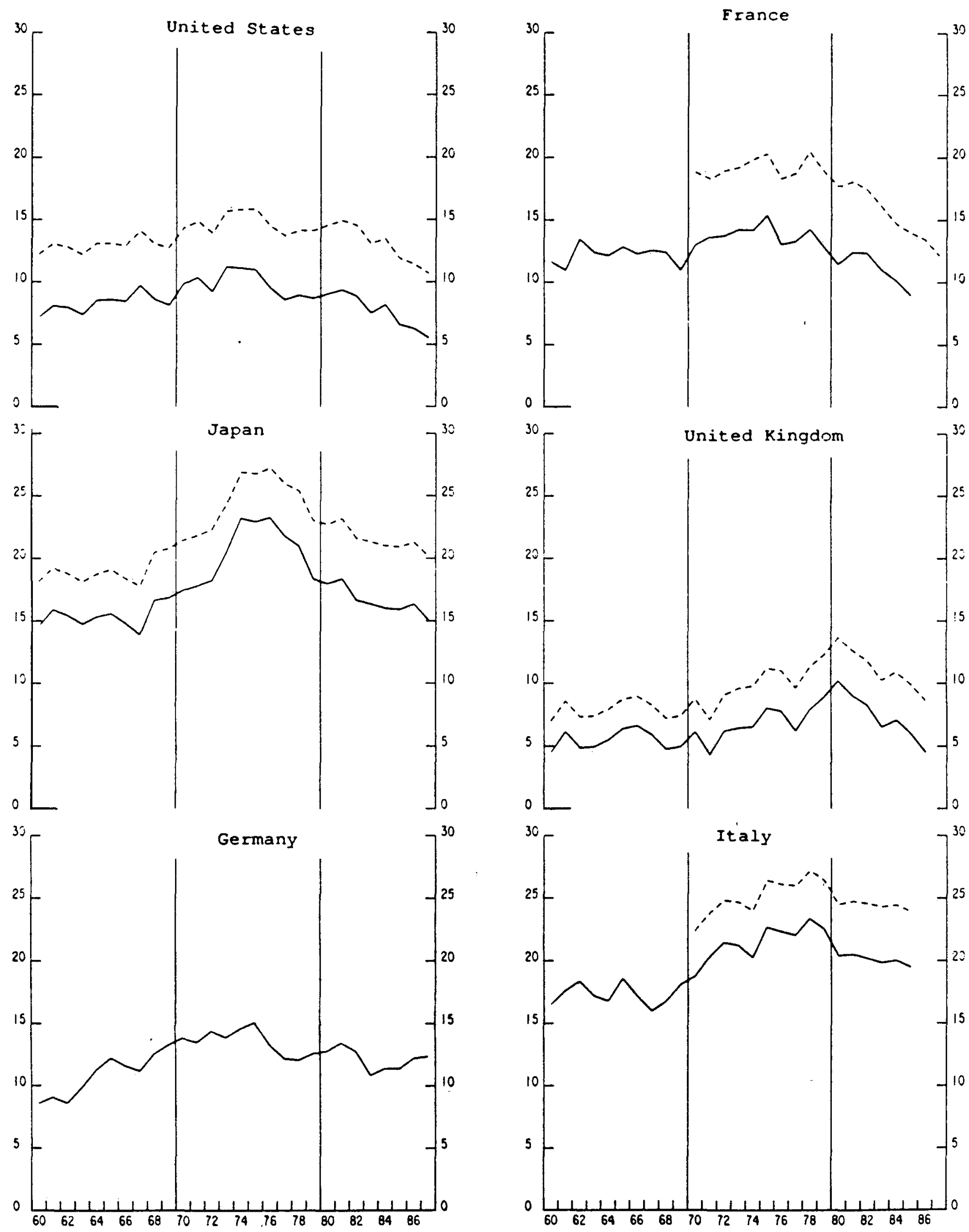

$30 \quad 30$

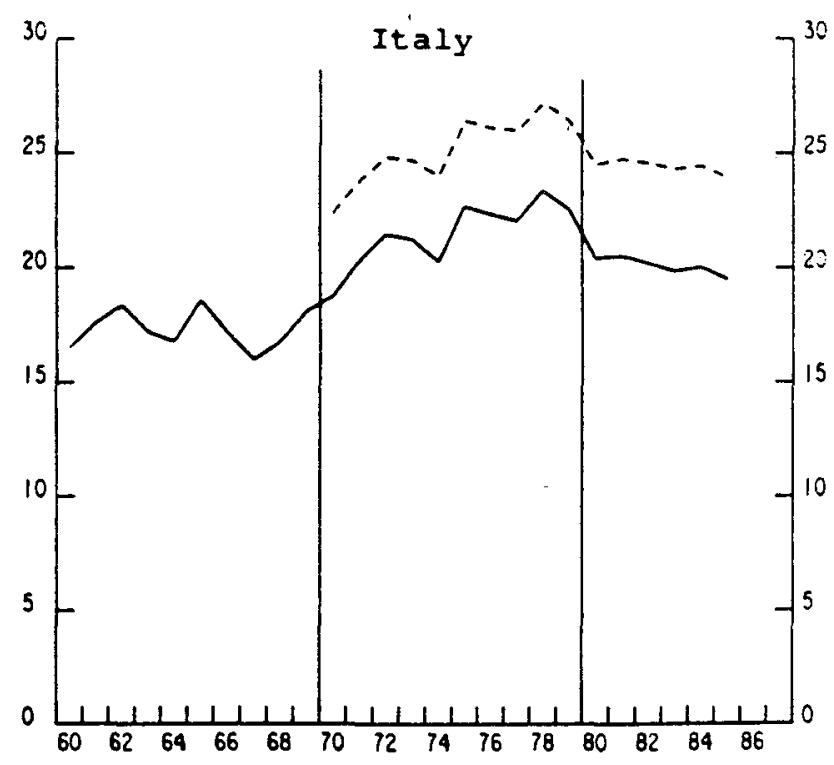


Chart $\mathrm{F}$ continued

Net saving ratio

Gross baving ratio
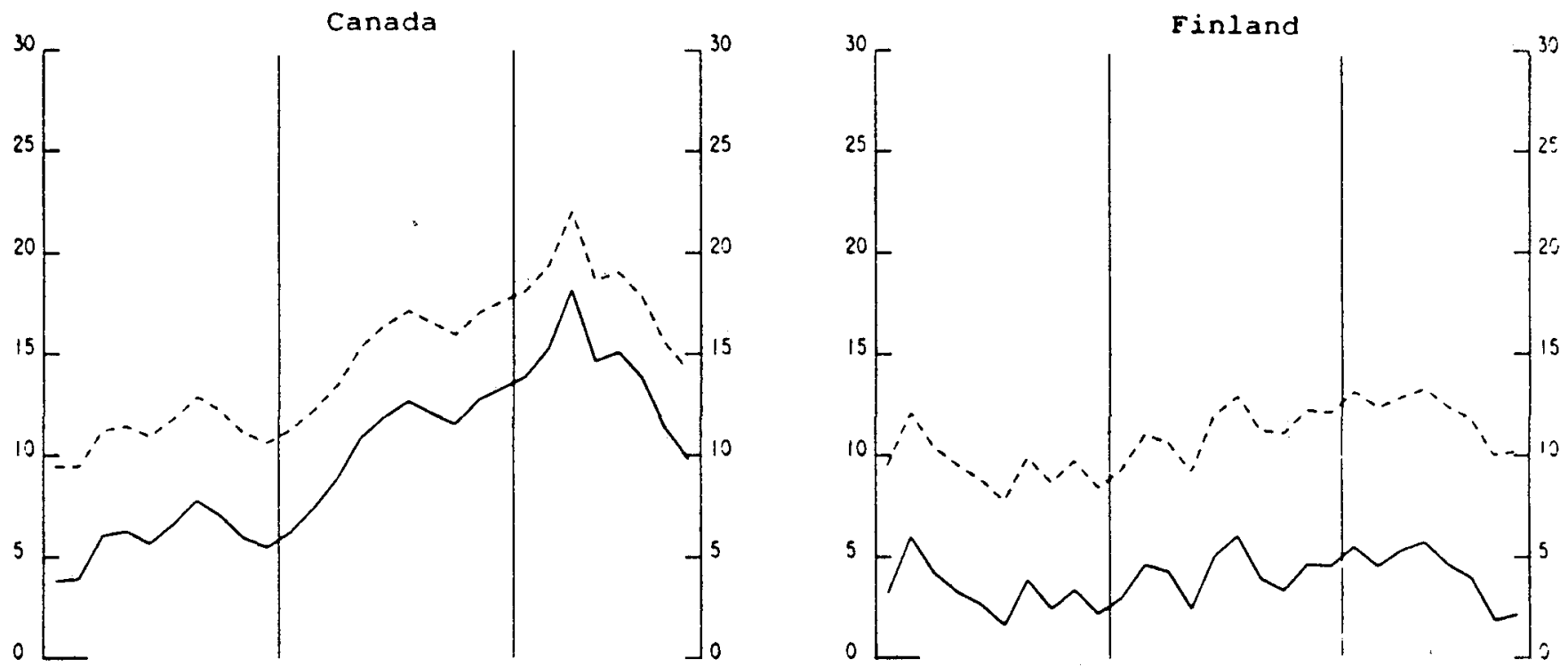

Finland

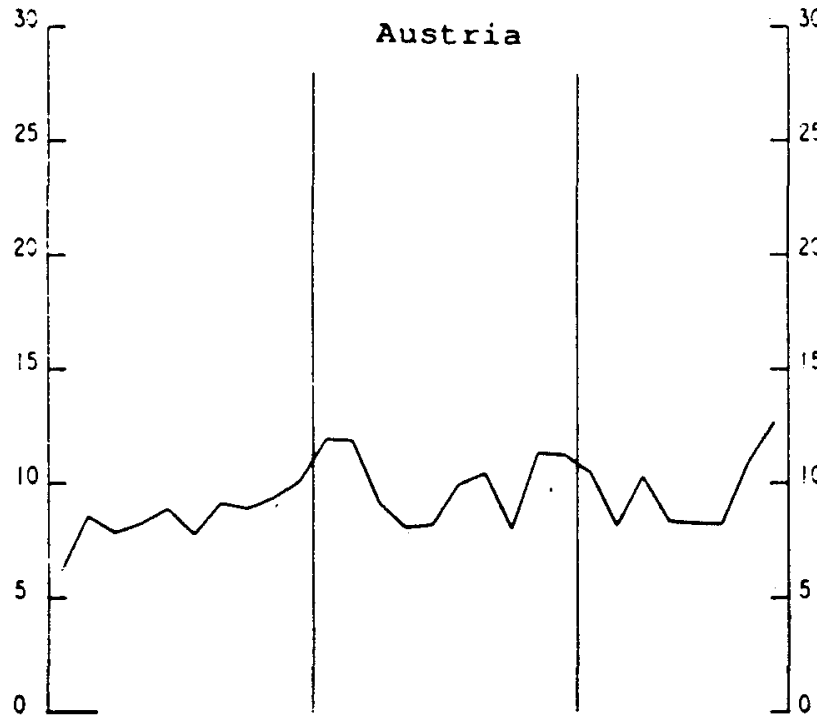

30

-
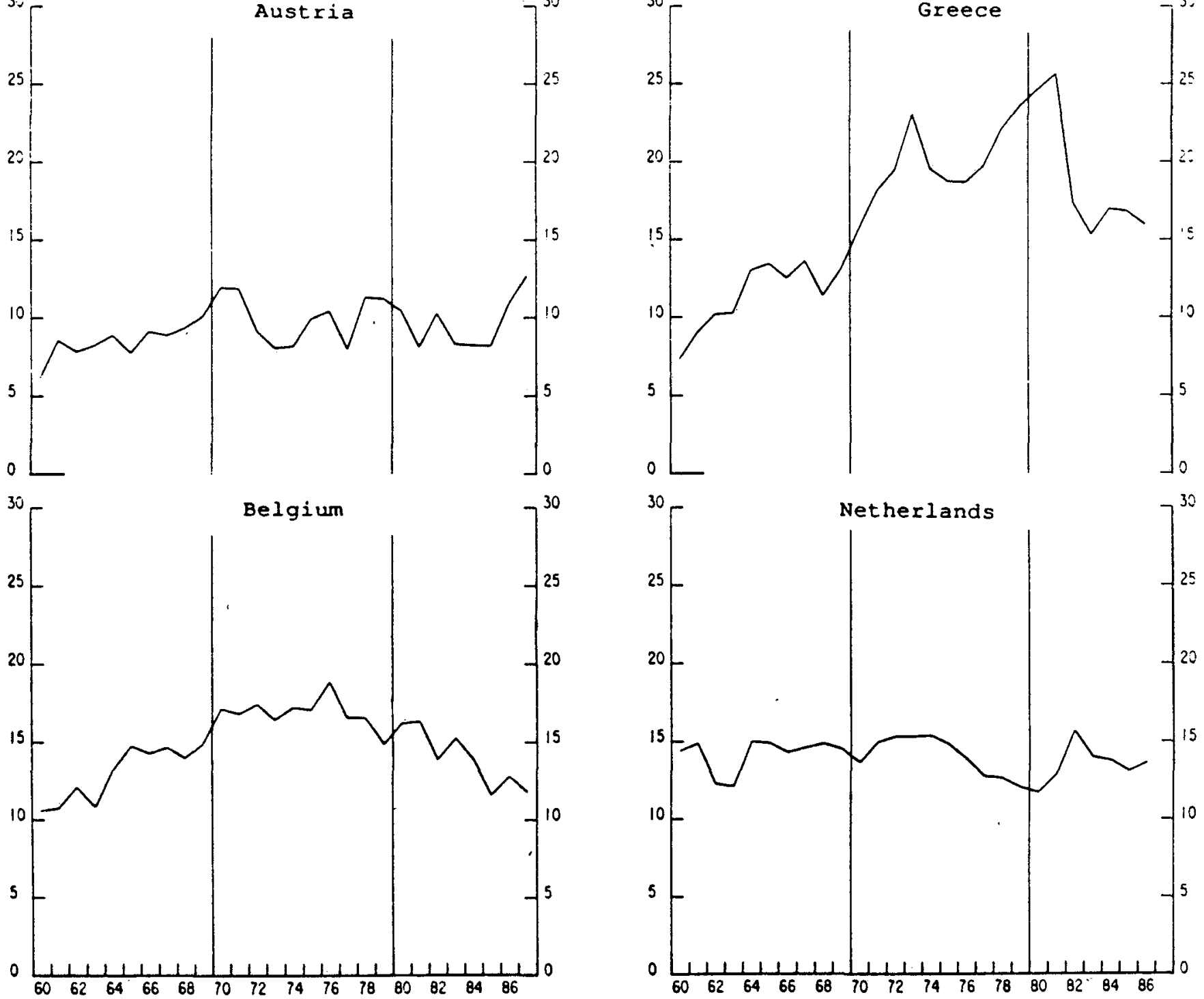


\section{Chart I continued}

Net saving ratio

Gross saving ratio

20

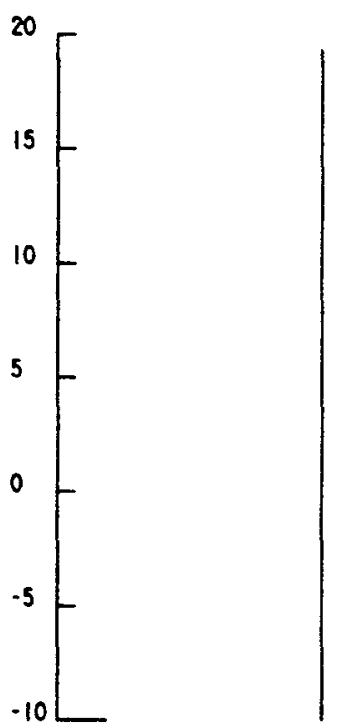

30

25

0
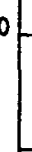

30

25

25

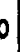

$20-$

10.

(1)

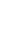

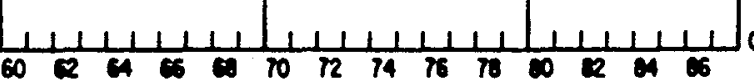

Norway

Spain

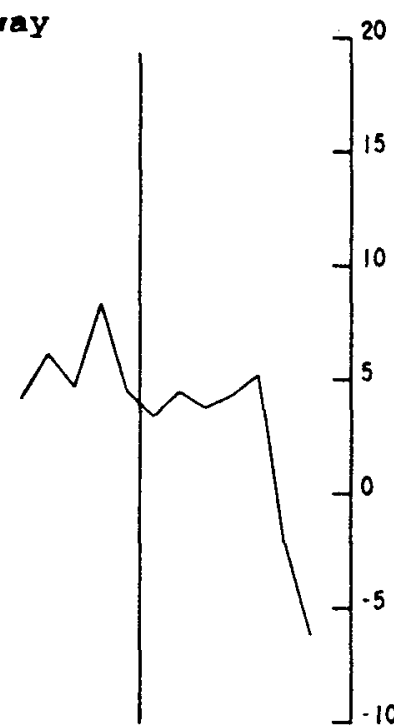

20

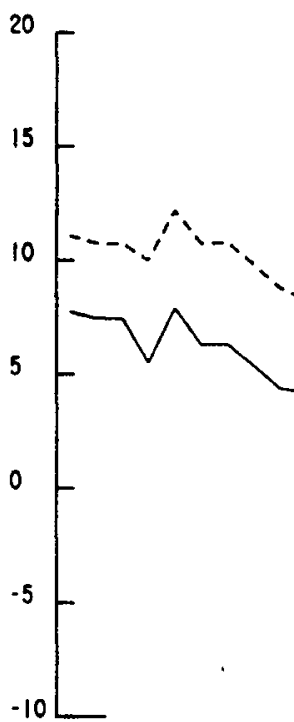

Sweden
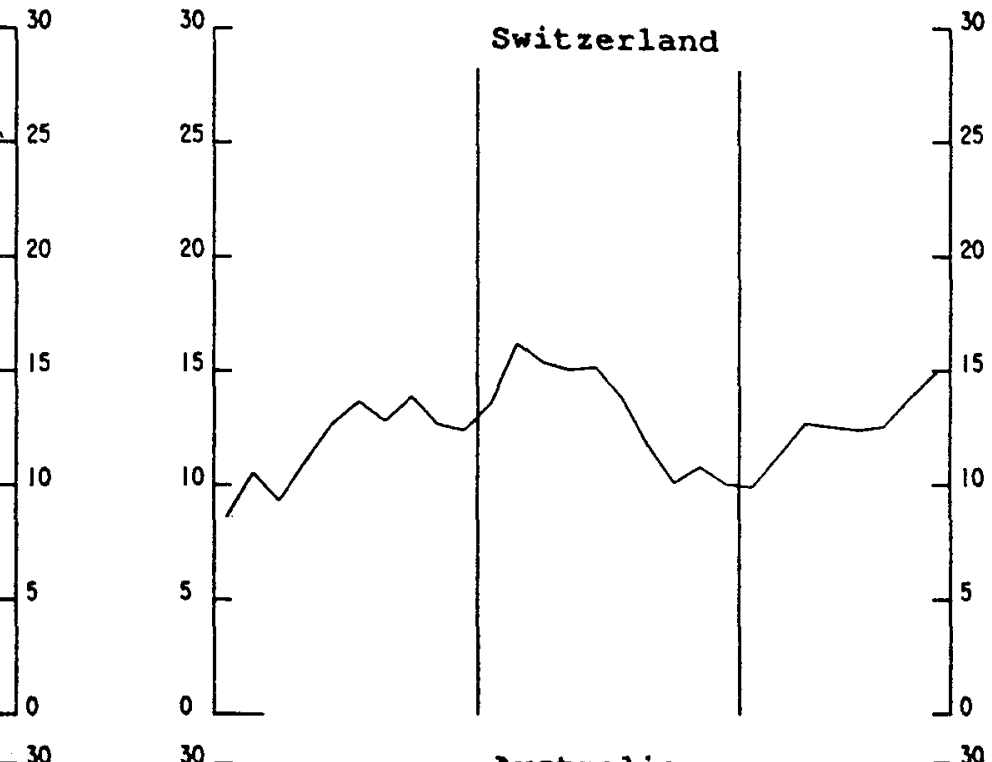

30

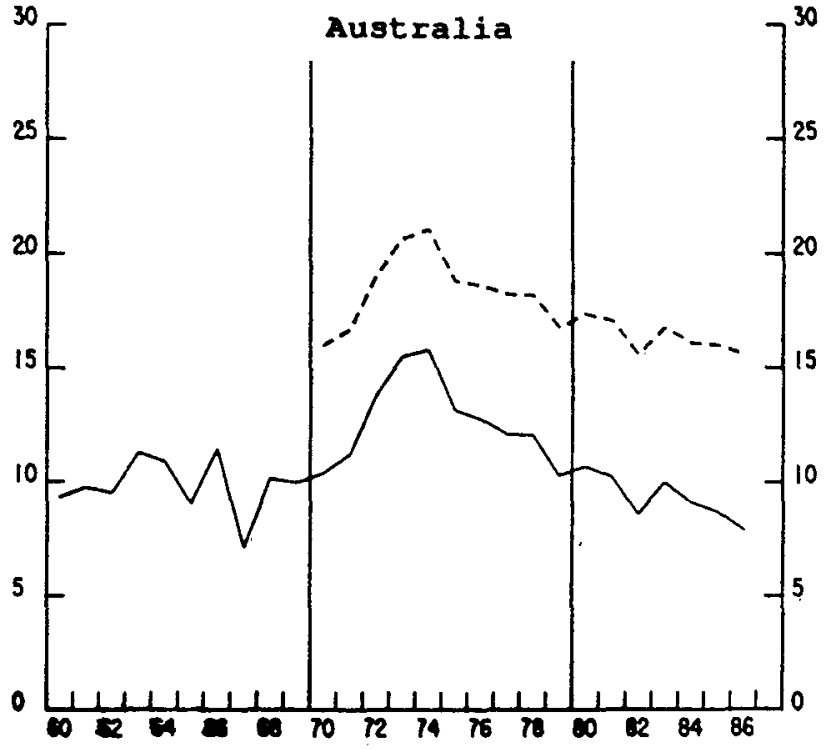

Source: OLCD.

nounl Mntiencl Acaminte. 
Chart G

INFLATION-ADJUSTED GROSS HOUSEHOLD SAVING RATIOS

Gross saving ratio

Inflation-adjusted saving ratio
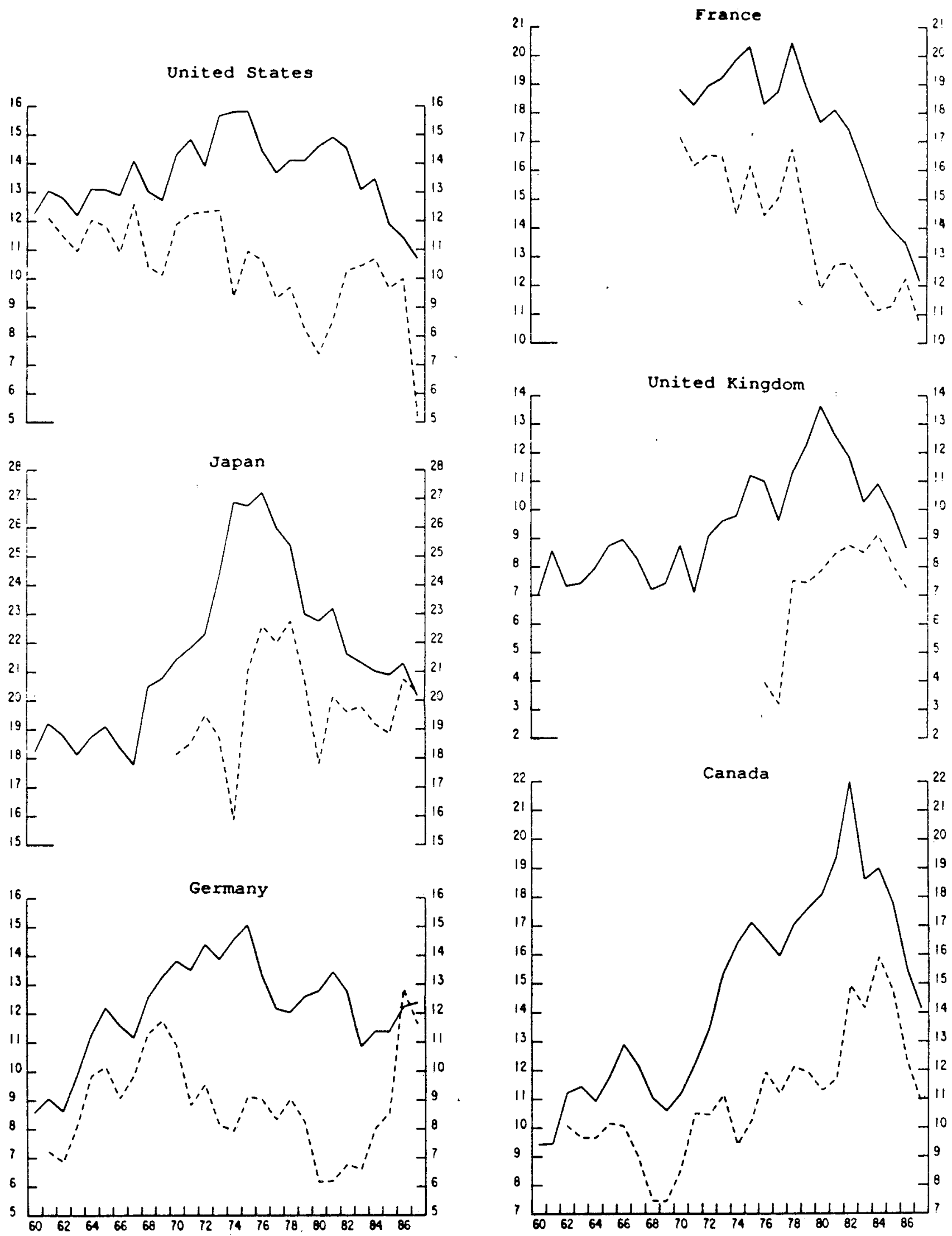

Note: Data for Italy are Included in Annex III.

Source: OECD, Annual National Accounts and Secretariat estimates. 
Chart $\mathrm{H}$

GROSS HOUSEHOLD SAVING. NET WORTH AND DEBT/INCOKE RATIOS UNITED STATES

SAVING RATIO (PER CENT)

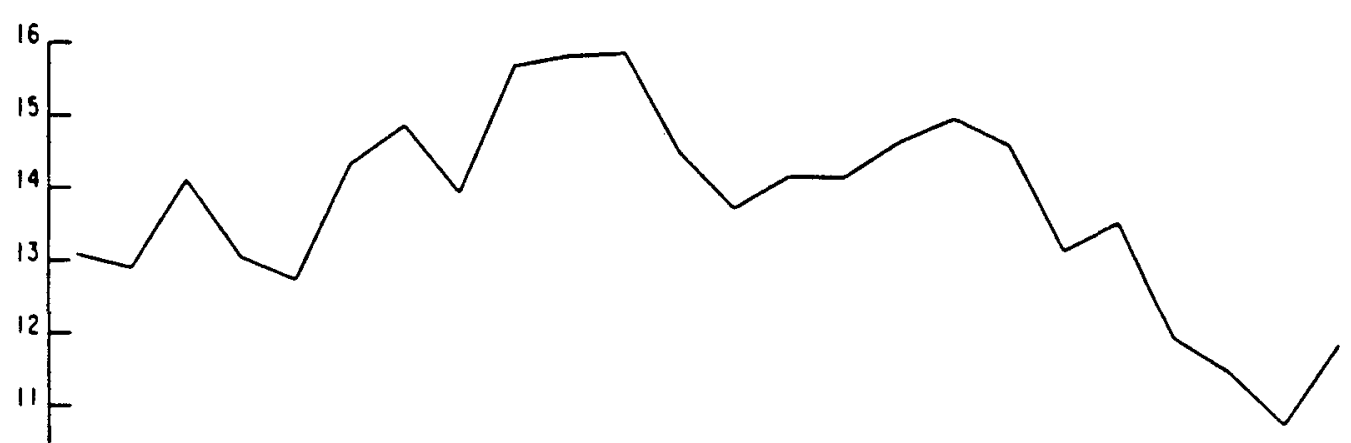

NET WORTH/INCONE

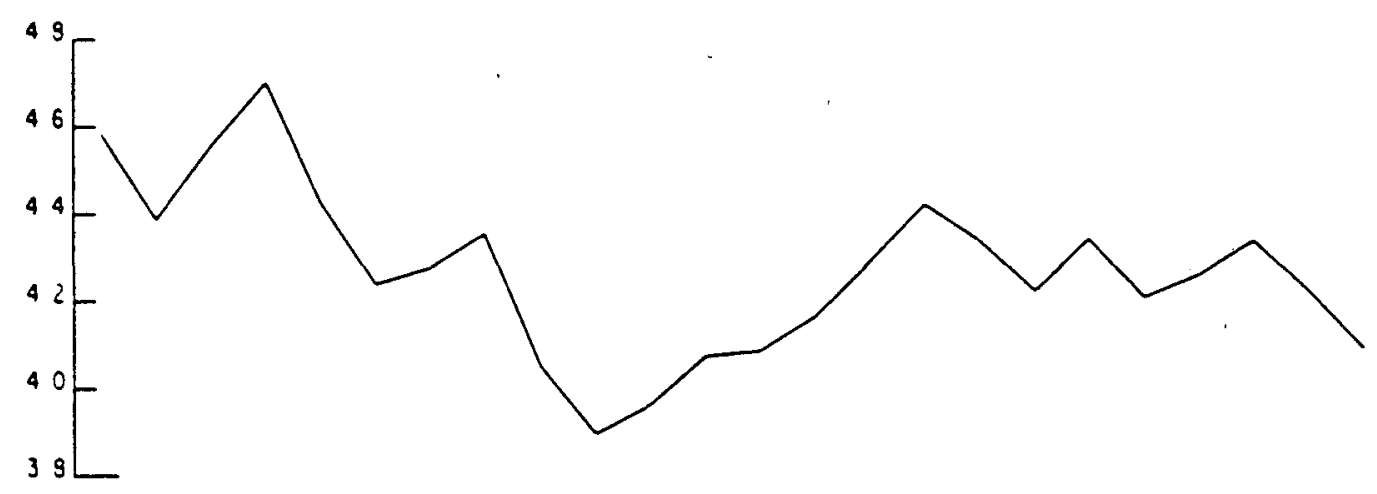

EOUITIES/INCONE
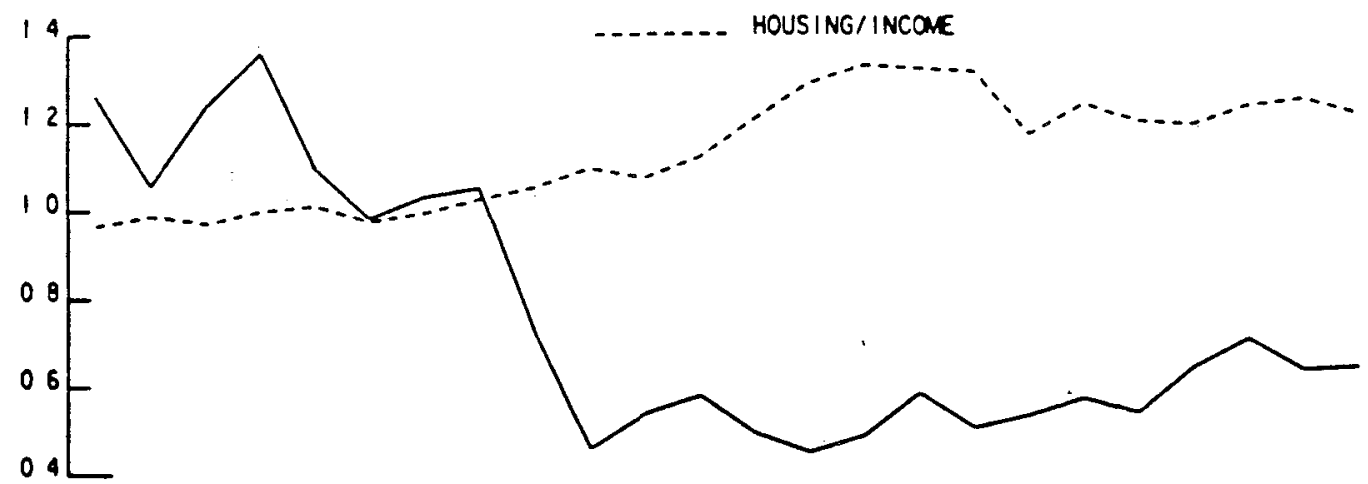

TOTAL LIABILITIES/INCONE

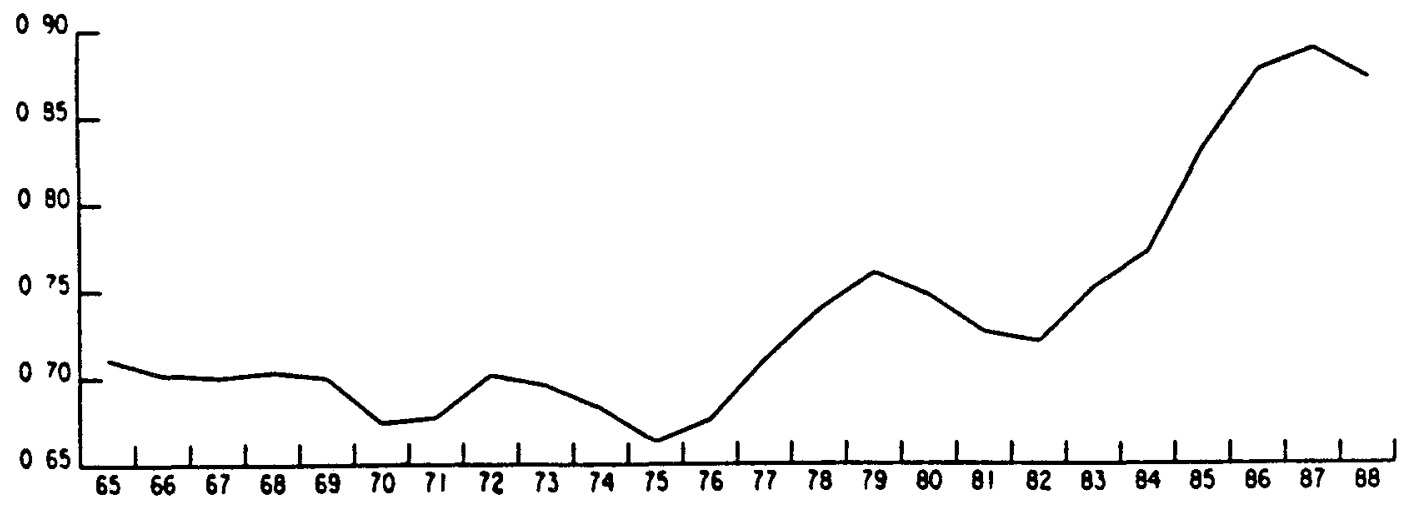




\section{Chart $H$ continued}

JAPAN

SAVING RATIO (PER CENT)
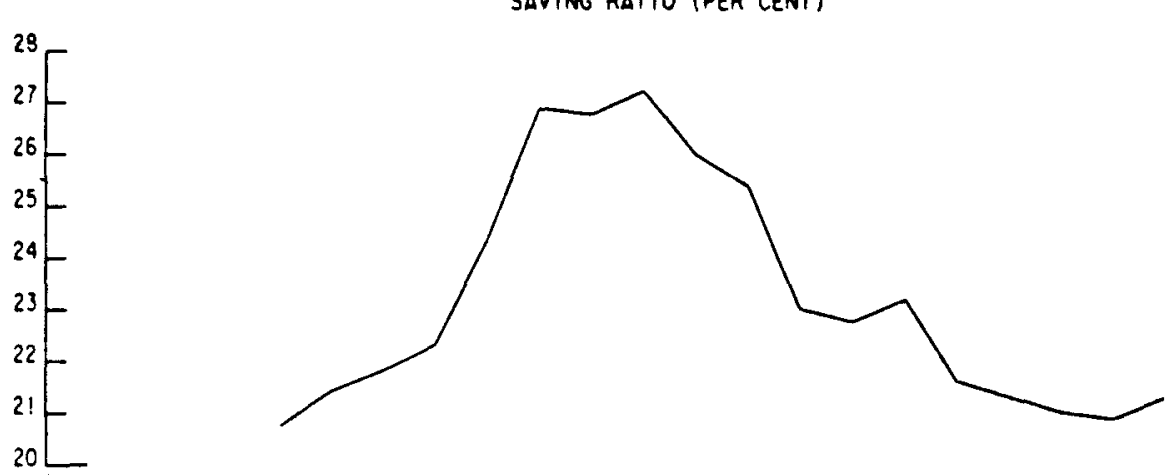

NET WORTH/INCONE
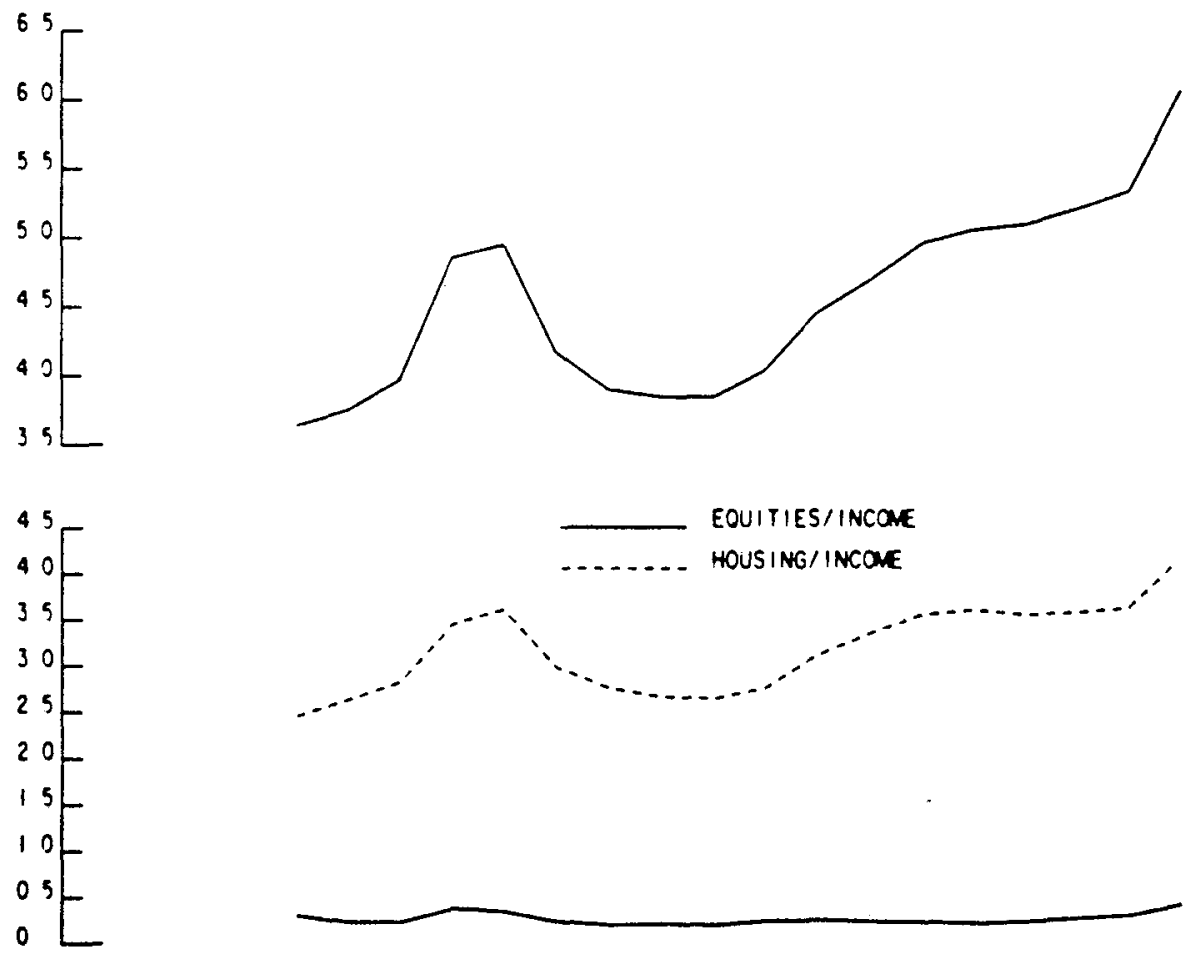

TOTAL LIAB!LITIES/INCONE

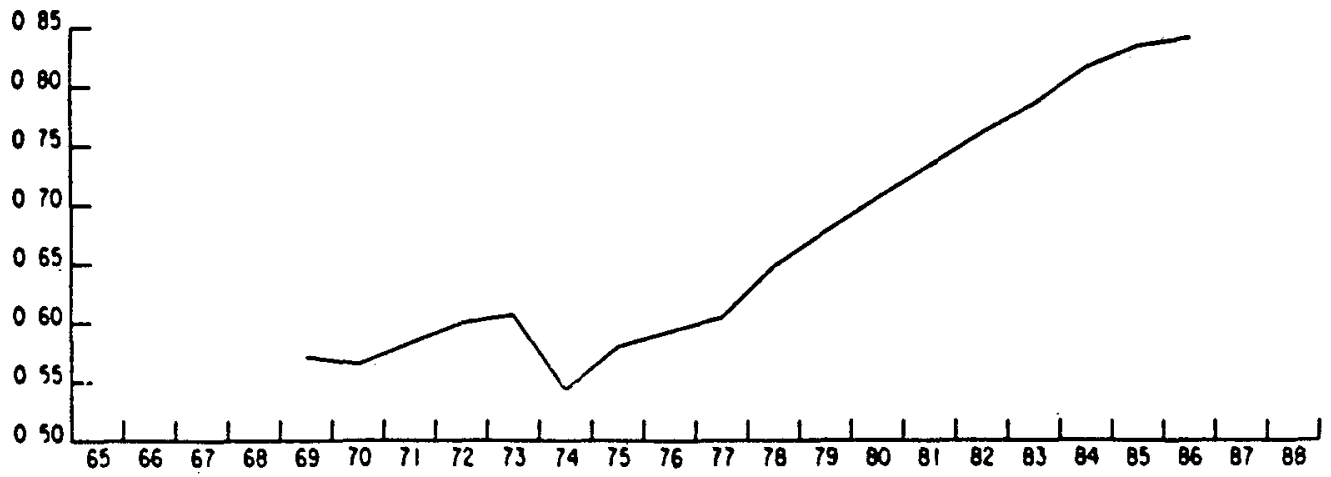


Chart II continued

GEPMANY
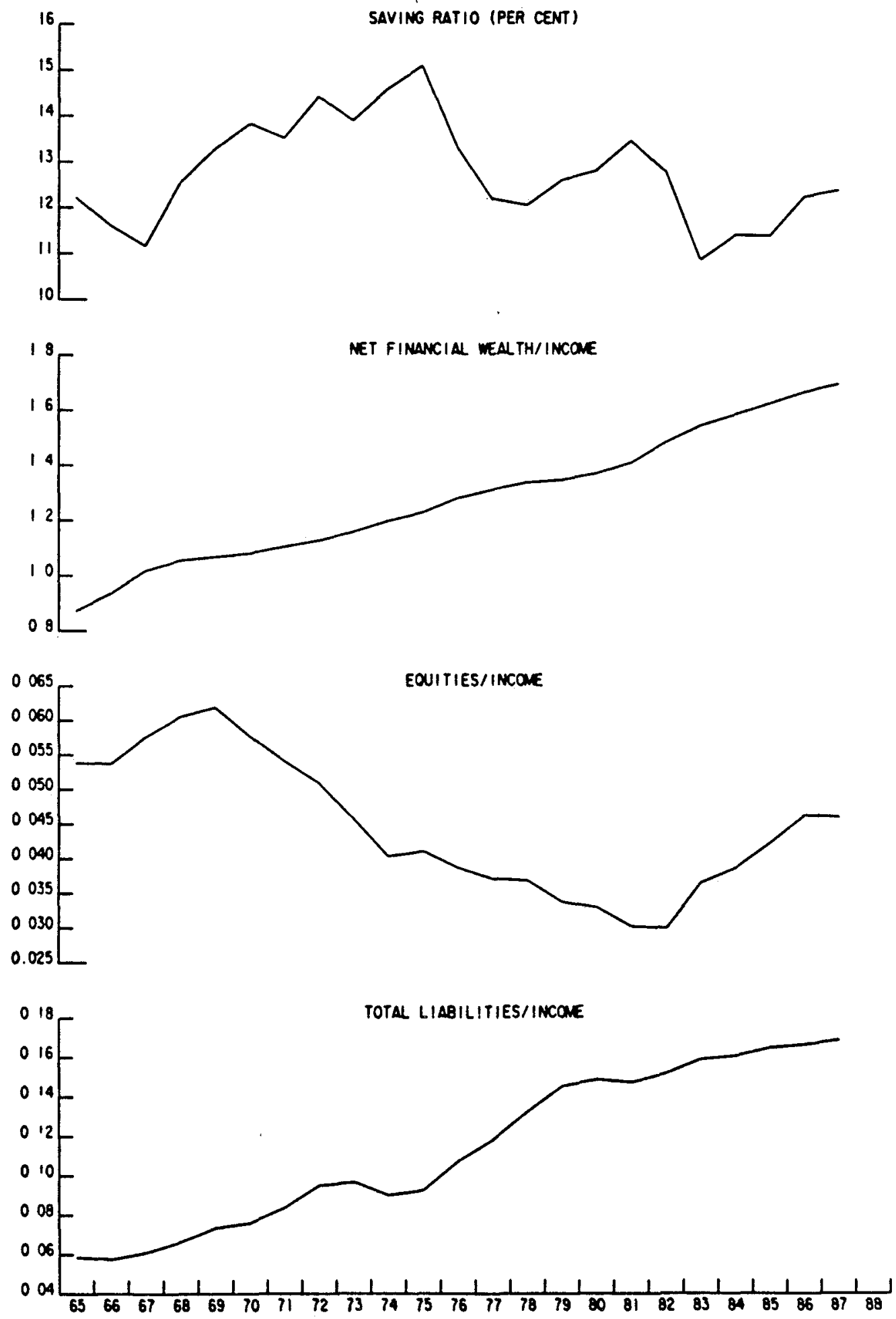


\section{Chart if continued}

\section{UNITED KINGDOM}
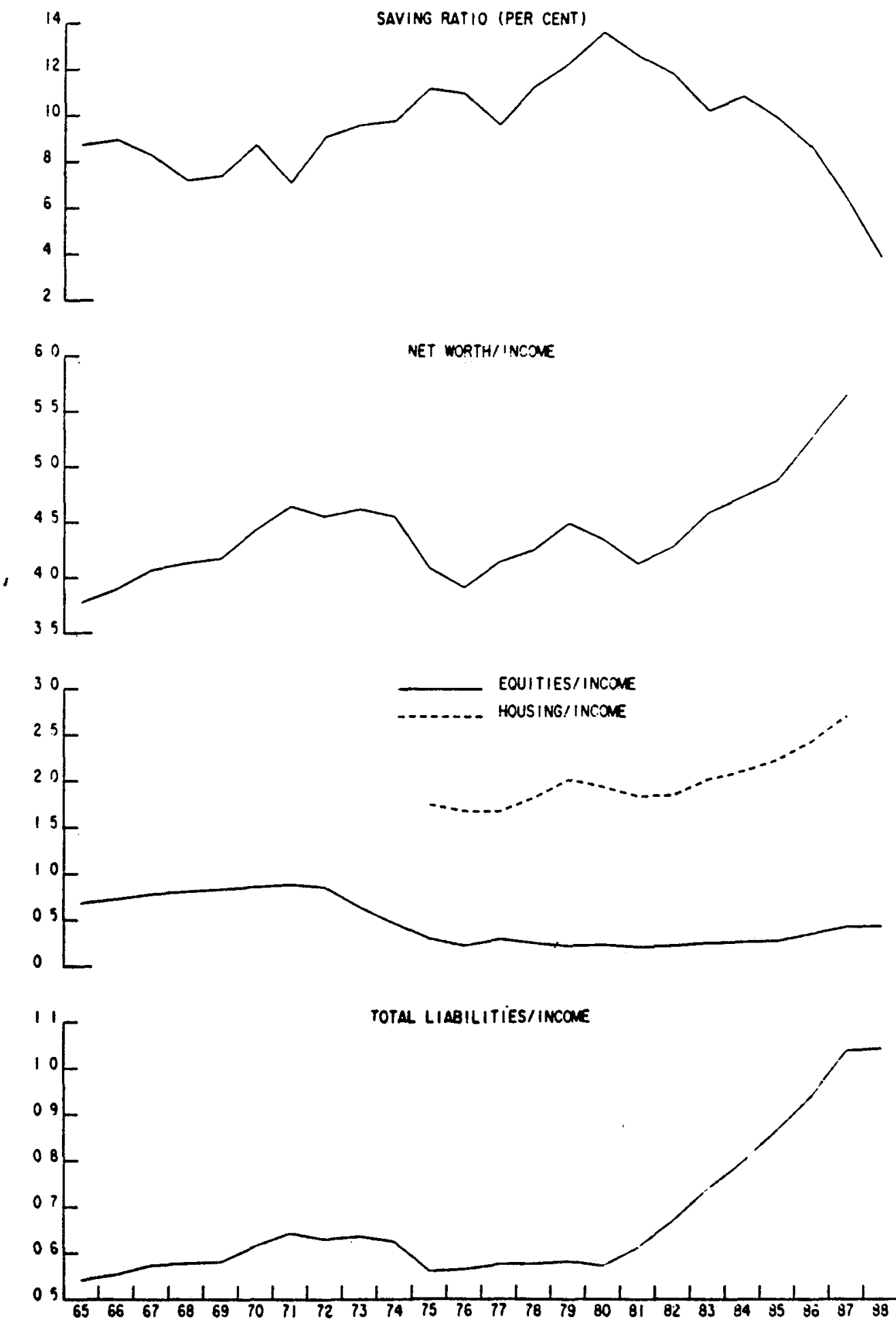


\section{Chart I continued}

\section{CANADA}
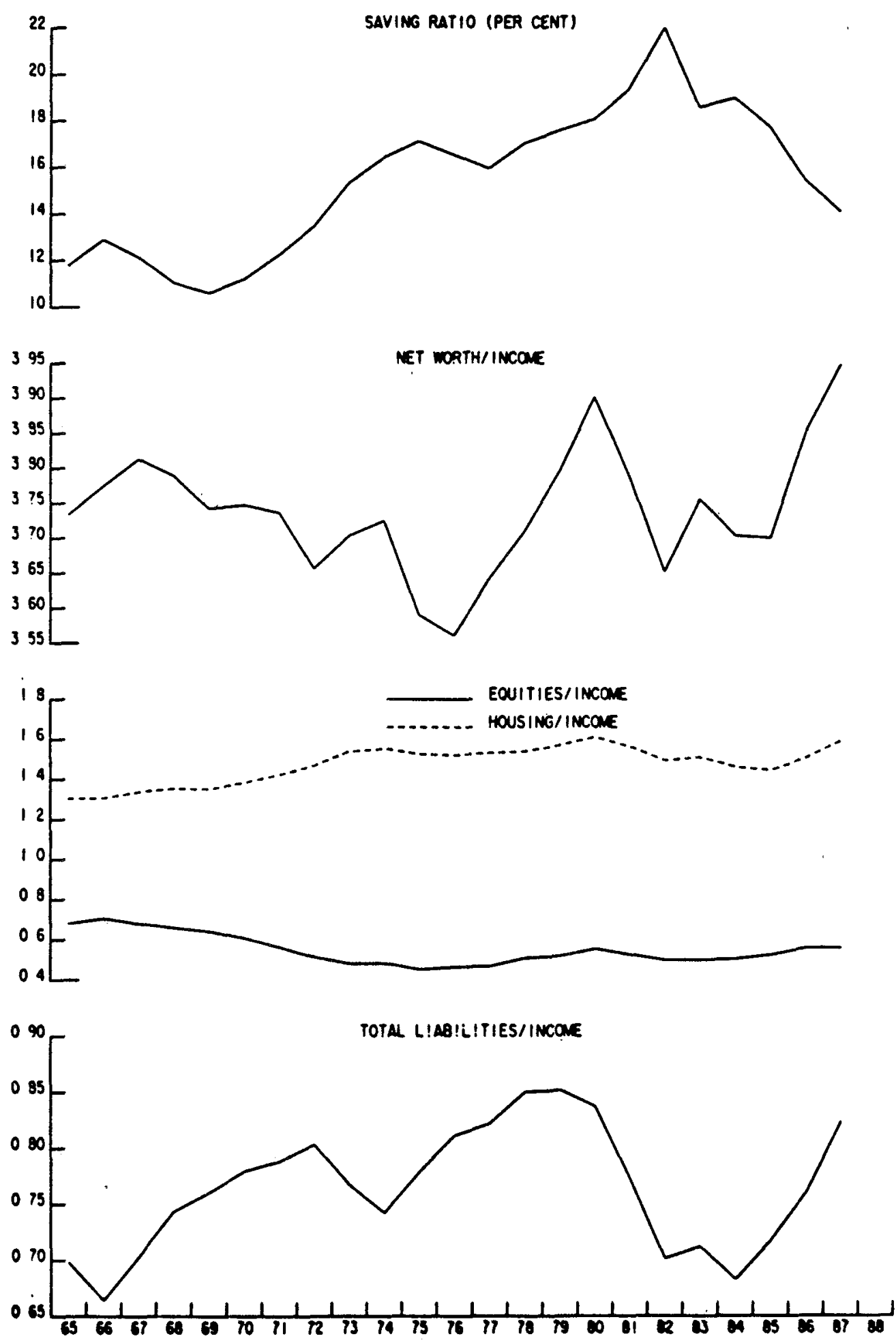

8ource: rederal Reserve, Contral statiatical office, Deutsche Bundesbank, Econouic Planning agency, statistics Canada. 


\section{MNeX I}

\section{BTATISTICAT MVIEX}

The statistical annex contains Table Al which gives extensive coverage of gross and net saving and investment ratios by country and by sector. This table is also the source for summary tables provided with the main paper.

The source of the data is the OECD's Annual National Accounts which attempts to provide data on an internationally comparable basis. Users should nevertheless be warned that the data are still not fully comparable. Major differences are noted at the end of the table and further issues of inter-country data comparability are discussed in Annex III. The latest data are for 1987 or earlier, depending on the country. The starting period also varies so that data for the 1960 s are not available for all countries. Other gaps represent incomplete sectoral coverage or cases where either gross and net figures are not available. 


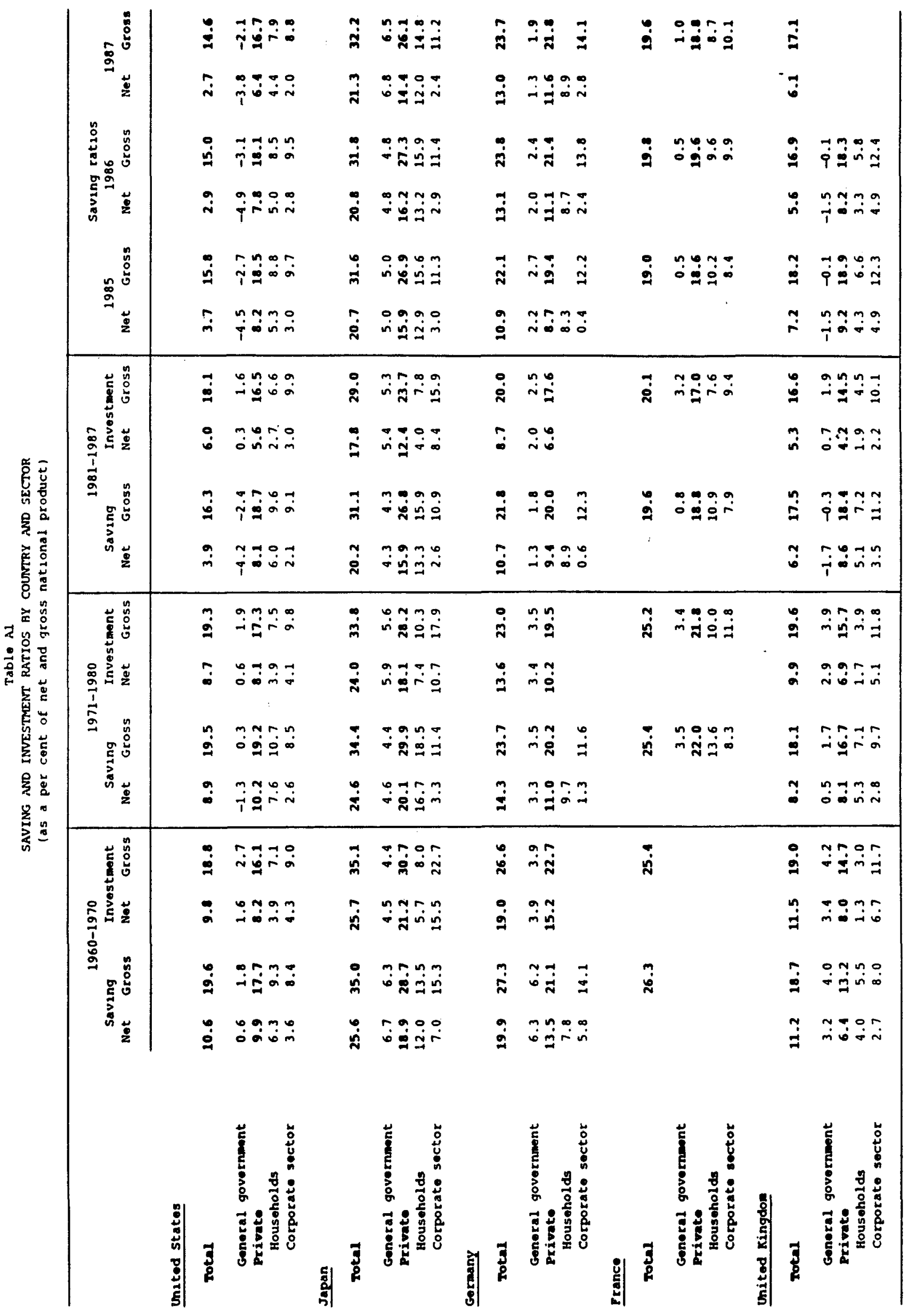




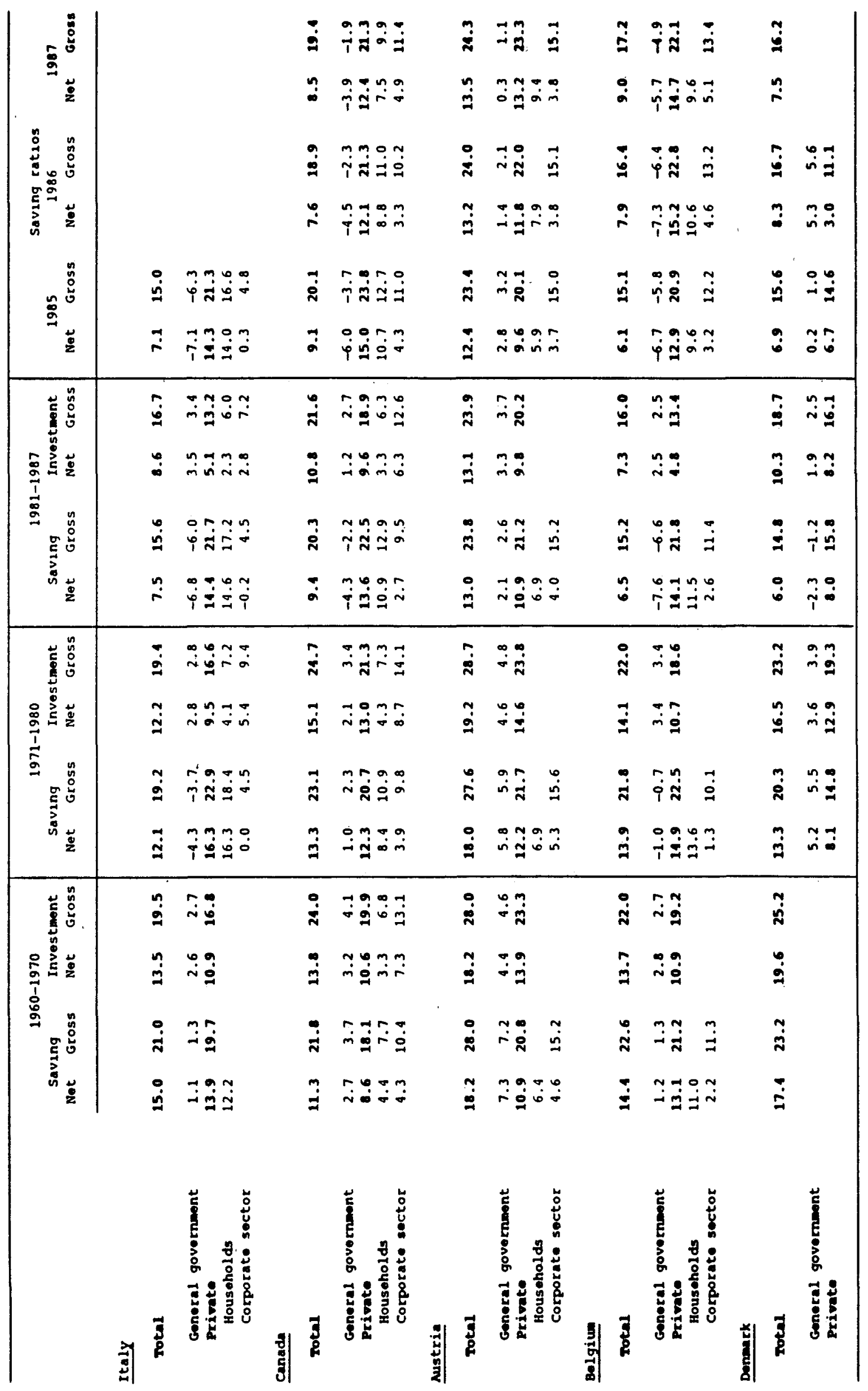




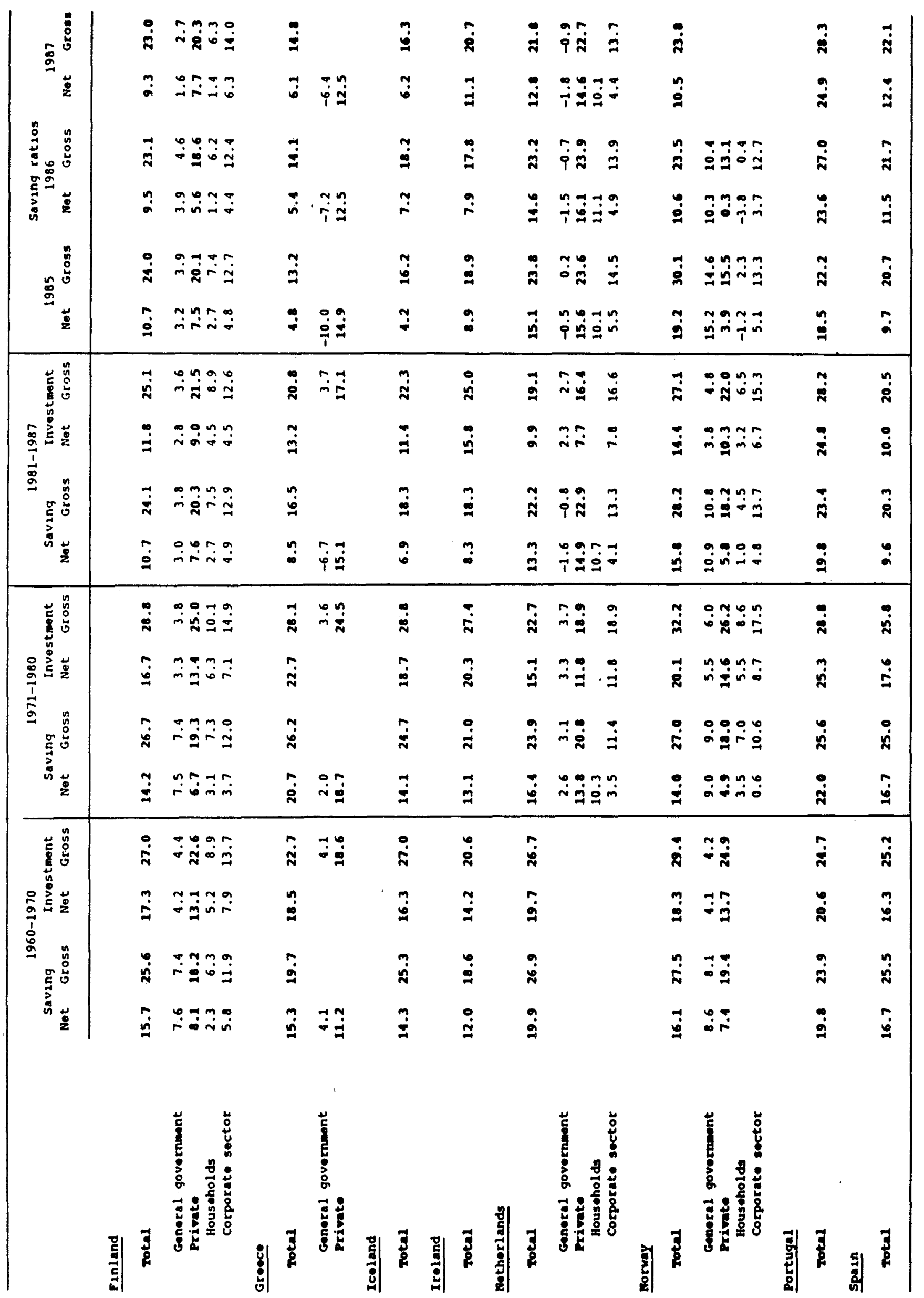




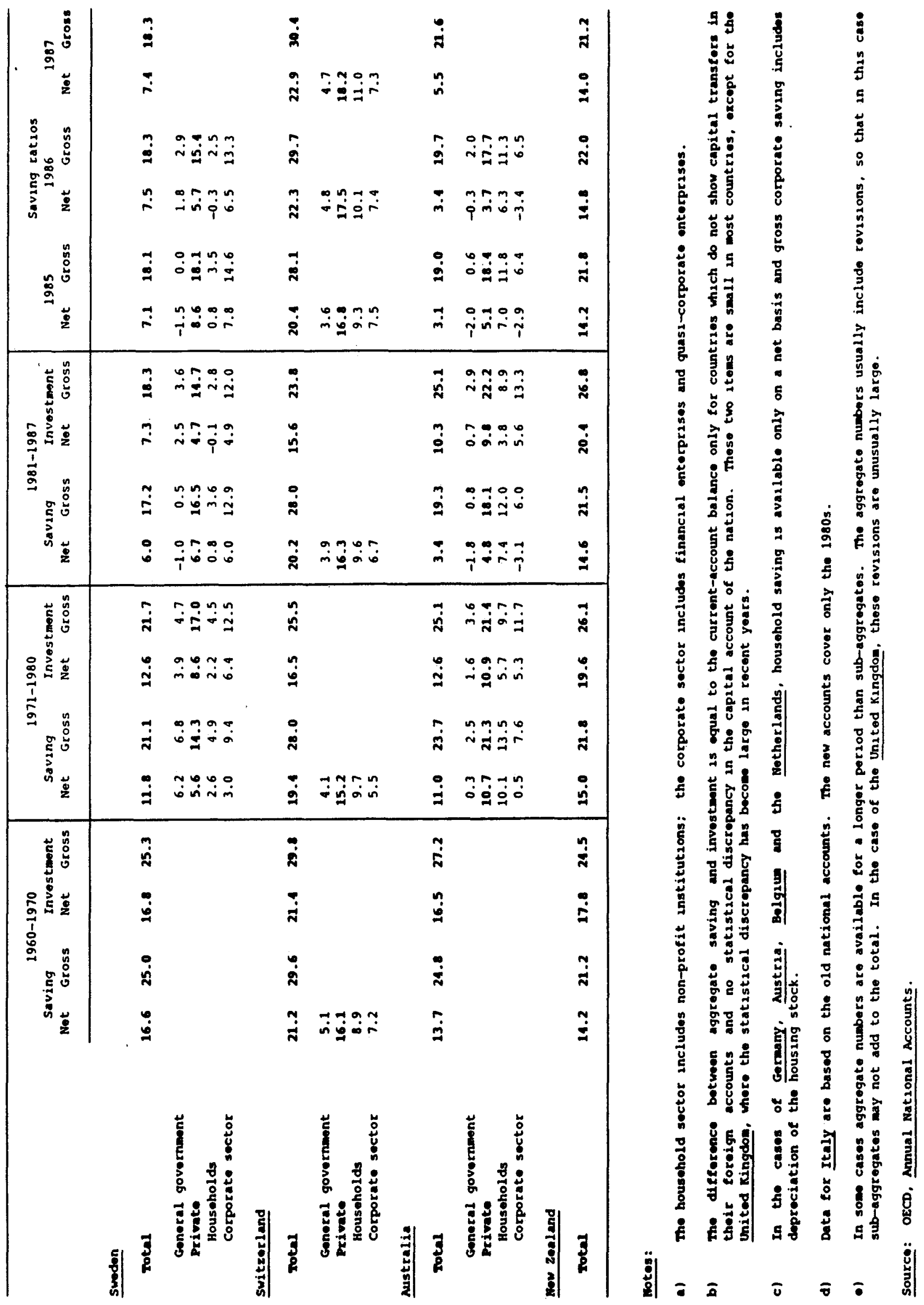


MNREX II

SAYING, INVESTMENT AND INTERNATIONAL CAPITAL TLONS

In a world of integrated markets saving will flow across national borders to seek the highest rate of return (adjusted for risk and taxation). These capital flows should tend to equalise demand and supply of available funds and establish one rate of return globally. In a simple exposition of the long-run determinants of saving and investment domestic investment is a downward-sloping function of the domestic real interest rate, while saving is positively related to the real interest rate; other factors affecting saving and investment are assumed to be purely random, so that apart from the interest rate there are no common determinants of saving and investment (1). Movements in the foreign capital account are a function of the difference between the domestic and foreign rates of return. In the case of perfect capital mobility differences in domestic and foreign rates will disappear completely. If restrictions on capital movements exist the rates of return on capital will differ and domestic investment will be, limited by domestic saving.

In a seminal article Feldstein and Horioka (1980) sought to provide a simple test of the degree of capital mobility between countries by regressing domestic saving on domestic investment ratios. Results for the period 1960 to 1974 for average ratios for the entire period as well as sub-periods showed that domestic saving corresponded with domestic investment nearly one to one. Also a more explicit model of the structural features which could explain inter-country differences in saving behaviour using income growth, differences in pension benefit-earnings replacement ratios or demographic structure as instrumental variables yielded the same results. In addition, Feldstein and Horioka related changes in investment ratios to changes in saving ratios. Although the estimated slope coefficient is somewhat lower in this case, it still implies that domestic investment rates adjust nearly fully to changes in saving rates.

Feldstein (1983) and others (Penati and Dooley (1984), Dooley, Frankel and Mathieson (1987), Tesar (1988)) extended the sample period to the early $1980 \mathrm{~s}$ and increased the country range. Some studies controlled for the endogeneity of saving and investment, for example letting both depend on the secular trend and cyclical fluctuations in income. Furthermore, governments may react to trade deficits by cutting expenditure or increasing taxes. In this case, total saving and investment may be correlated for reasons independent of capital mobility. Other studies tested for the effect of different country size on the basic results. Changes in saving or investment in large countries could influence interest rates in world financial markets as well as saving and investment elsewhere. It was also argued that, given the greater diversity of larger economies, the likelihood that sectoral or regional saving/investment imbalances would cancel was larger than in smaller countries. However, even after taking account of these factors, the close association between national saving and investment still came out as a robust empirical regularity, at least for the industrialised countries. 
In a similar vein Sachs (1981 and 1983) analysed the relationship between cuxrent-account and investment ratios. If foreign capital is in infinitely elastic supply at the given world interest rate, an exogenous increase in domestic investment would be fully financed by capital imports. He found a significant negative relationship and concluded that about two-thirds of a change in the investment ratio is financed by capital inflows and the rest by domestic sources. In a later study Penati and Dooley (1984) re-examined the issue and found that the negative relationship only held for some sub-periods and was heavily dependent on the choice of countries in the sample. Some results of the different studies are summarised in Table A2.

Turnex (1986) was the first to provide evidence that the relationship was less close than before. A pooled cross-section of investment and saving ratios covering 23 OECD countries indicated a somewhat lower coefficient for the years 1960 to 1974 than in the initial reldstein-Horioka study but a considerably lower one for 1975 to 1983: only about two-thirds of domestic investment was financed by domestic saving. A repetition of Feldstein's early work (reported in the main text, Table 2) confirms this finding: domestic saving ratios have become much less important as determinants of domestic investment. While the coefficients in the regressions for the $1960 \mathrm{~s}$ and early 1970 s are close to one, they drift down later to reach a low of only 0.58 for the last five-year period from 1983 to 1987.

A whole range of factors coúld explain substantial imperfections in international capital markets and the close correlation between domestic saving and investment:

a) Investment risks across countries and currencies are not perfectly correlated and risk aversion may become greater for longer-term and less liquid assets.

b) Capital flows may react little to yield differentials due to a low elasticity of substitution in asset demand functions. This point seems to be especially important for substitution between liquid short-term assets and long-term fixed assets.

c) Tariff and non-tariff barriers are important policy parameters which influence the location of investment.

d) Foreign direct investment is also influenced by firm-specific marketing considerations. A recent study (Henry, 1988) points to a close correlation between U.S. export and U.S. direct investment in Canada, the Netherlands, France and Italy.

e) Policy under a system of fixed exchange rates, as prevailed until the early 1970s, was geared towards current-account equilibrium and hence a balance between national saving and investment.

In addition, cross-country differences in effective marginal rates of income taxation, particularly in the context of liberalised capital markets, are an important component in decisions on where to locate physical and financial investment. One condition to achieve the maximisation of world income is the international equalisation of before-tax marginal rates of return. Where international differences in before-tax rates of return exist, 
world income can be increased by simply reallocating investment from low-return countries to high-return countries.

In the presence of international differences in income taxation, cross-country capital flows will tend to equalise after-tax rates of return. Liberalisation of capital markets will thus lead to investment in countries with a suitably attractive combination of high before-tax rate of return and low taxes. Where investment projects are financed by capital inflows, the current-account deficits have to be serviced by the return on the investment projects at the given world interest rate (assuming a "small-country" perspective). Current-account deficits and income outflows are sustainable in the long run, if a country's before-tax return is above the world interest rate. For countries which attract foreign investment via generous tax incentives, but where the before-tax rate of return is far below the servicing cost, balance-of-payments problems are likely to arise -- as may have been the case in Ireland (OECD, 1985) or in New zealand, where the Government promoted large projects, which had some positive employment and output effects in the short term, but were not economically viable (OECD, 1987). If differentially generous tax incentives have been important determinants of the international flow of savings, there is a potential for a world output gain by shifting capital from the low-tax to the high-tax country (Fukao and Hanazaki, 1987).

Results of this simple presentation of the effects of tax wedges on international capital allocation are altered if the country undertaking the investment is sufficiently large to influence world interest rates. Additional investment due to tax changes will increase interest rates and reduce investment elsewhere. The interest-rate increase-will, however, be cushioned as additional saving is induced everywhere (2). Fukao and Hanazaki (1987) estimated that a tax incentive equivalent to a 1 percentage point cut in the real cost of capital would increase the world interest rate by 0.41 percentage point, if the change were to take place in the United states, but by only 0.08 percentage point for the same change in the United Kingdom. Equally important differences are reported in this study concerning changes in the external asset position. The efficient allocation of saving also requires that such saving not be used to sustain high levels of government consumption expenditure in any country -- the complaint made in recent years against the United states -- though given fungibility of saving the key issue is whether the level and quality of investment is sufficient to service the capital infilow.

Openness also changes the perspective on saving promotion schemes. In a closed economy, saving incentives will tend to reduce interest rates, encourage investment, increase capital intensity and labour productivity and finally incomes. An increase in saving in an open economy will partly flow to other countries, with the government incentives providing a subsidy to investment projects elsewhere.

Rules of international taxation are exceedingly complex. The effects of tax wedges are limited to some extent by international tax agreements. They usually prevent double taxation but cannot prevent international competition for investment projects through other fiscal instruments. Recent tax reform measures and proposals show that increased openness has created pressures in many countries to harmonize tax systems (Hagemann et al., 1987). 
MOTzS

1. These propositions are based on a simple model of the long-run determinants of saving, investment and capital flows (see Feldstein, (1983) and Dooley, Frankel and Mathieson (1987)).

2. Adjustment to a new equilibrium is much more complicated than this simple exposition suggests. Short-run effects may differ from long-run effects and a richer description of possible outcomes has to take into account the endogeneity of labour markets, competitiveness, exchange rates, etc. See, for recent work in this area, $L$. Goulder and B. Eichengreen (1988). 
RETRRECES

Dooley, M., J. Frankel and D. Mathieson (1987), "International capital mobility: what do saving-investment correlations tell us?", IMF Staff Papers, International Monetary Fund, Vol. 34 (September).

Feldstein, M. (1983), "Domestic saving and international capital movements in the long run and the short run", European Economic Review 21.

Feldstein, M. and C. Horioka (1980), "Domestic saving and international capital flow", The Economic Journal, 90 (June).

Fukao, M. and M. Hanazaki (1987), "Internationalisation of financial markets and the allocation of capitaln, OECD Economic studies (Spring), Pp. 35-92.

Goulder, L. and B. Eichengreen (1988), "Saving promotion, investment promotion and international competitiveness", NBER horking Paper No. 2635 (June).

Hagemann, R., B. Jones and B. Montador (1987), "Taxation reform in OECD countries: economic rationale and consequences", OECD Working Papers No. 40 (August).

Henry, J. (1988), "Investissement direct des Etats-Unis dans les pays occidentaux depuis 1980 : une évaluation économétrique", Observations et diagnostics économiques, Bureau de l'OFCE, No. 26 (janvier).

OECD (1985), OECD Economic Survey of Ireland (April).

OECD (1987), OECD Economic Survey of New Zealand (March).

Penati, A. and M. Dooley (1984), "Current account imbalances and capital formation", IMF Staff Papers, International Monetary Fund, Vol. 31 (March).

Sachs, J. (1983), "Aspects of the current account behavior of OECD economies", in: E. Claassen and P. Salin (eds.), Recent issues in the theory of flexible exchange rates, Amsterdam.

Sachs, J. (1981), "The current account and macroeconomic adjustment in the 1970s", Brookings Rapers on Economic Activity: 1.

Tesar, I. (1988), "Savings, investment and international capital flows", Brookings Discussion Papers in International Economics, No. 64 (June).

Turner, P. (1986), "Savings, investment and the current account: an empirical study of seven major countries 1965-84", Bank of Japan, Monetary and Economic Studies (October). 
Sable 2

THE RELIION RETWEN BAVTKGB NAD INVERMET RATIOB:

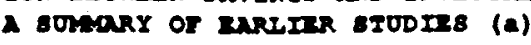

\begin{tabular}{|c|c|c|c|c|c|c|c|}
\hline & & Regreenton & -quation & & $x^{2}$ & $\underset{\text { period (b) }}{\operatorname{sample}}$ & $\begin{array}{l}\text { mumber of } \\
\text { countr10. }\end{array}$ \\
\hline \multirow[t]{4}{*}{$\begin{array}{l}\text { Toldetein, Borloka } \\
(1980)\end{array}$} & $(I / Y)$ & $\begin{array}{c}0.035 \\
(0.018)\end{array}$ & $+\quad \begin{array}{l}0.89 \\
(0.074)\end{array}$ & $(8 / Y)$ & 0.91 & $1960-74$ & 16 \\
\hline & $(I / Y)$ & $\begin{array}{c}0.029 \\
-\quad(0.015)\end{array}$ & $+\quad \begin{array}{c}0.91 \\
(0.060)\end{array}$ & $(8 / Y)$ & 0.92 & $2960-64$ & 16 \\
\hline & $(I / Y)$ & $=\quad \begin{array}{c}0.039 \\
(0.025)\end{array}$ & $+\quad \begin{array}{c}0.87 \\
(0.201)\end{array}$ & $(8 / Y)$ & 0.83 & $1965-69$ & 16 \\
\hline & $(I / Y)$ & $=\quad \begin{array}{c}0.039 \\
(0.024)\end{array}$ & $+\quad \begin{array}{c}0.87 \\
(0.092)\end{array}$ & $(8 / Y)$ & 0.85 & $2970-74$ & 16 \\
\hline Feldatein (2983) & $(I / Y)$ & $\begin{array}{c}0.046 \\
(0.042)\end{array}$ & $+\quad \begin{array}{l}0.87 \\
(0.285)\end{array}$ & $(8 / Y)$ & 0.57 & $1975-79$ & 27 \\
\hline Sachs (1981) & $\Delta(\mathrm{CX} / \mathrm{Y})$ & $\begin{array}{l}-0.30 \\
(0.254)\end{array}$ & $\begin{array}{c}0.59 \\
(0.100)\end{array}$ & $\Delta(I / Y)$ & 0.73 & $1968-73$ to $1974-79$ & 15 \\
\hline \multirow[t]{3}{*}{$\begin{array}{l}\text { Penat1, Dooley } \\
\text { (1984) }\end{array}$} & $(I / Y)$ & $\begin{array}{l}0.030 \\
(0.034)\end{array}$ & $+\begin{array}{c}0.88 \\
(0.141)\end{array}$ & $(8 / Y)$ & 0.71 & $1971-81$ & 19 \\
\hline & $(\mathbf{C X} / \mathbf{Y})$ & $\begin{array}{c}0.033 \\
(0.028)\end{array}$ & $\begin{array}{l}0.19 \\
(0.114)\end{array}$ & $(I / Y)$ & 0.11 & $1971-81$ & 19 \\
\hline & $\Delta(C \lambda / Y)$ & $\begin{array}{l}-0.015 \\
-\quad(0.005)\end{array}$ & $+\begin{array}{c}0.05 \\
(0.208)\end{array}$ & $\Delta(I / Y)$ & 0.01 & $1949-59$ to $1971-81$ & 19 \\
\hline \multirow[t]{2}{*}{$\begin{array}{l}\text { Dooley, Frankel, } \\
\text { Matbleoon (1987) }\end{array}$} & $(I / Y)$ & $\begin{array}{l}0.069 \\
(0.026)\end{array}$ & $+\quad \begin{array}{c}0.75 \\
(0.104)\end{array}$ & $(8 / Y)$ & 0.79 & $1960-73$ & 14 \\
\hline & $(I / Y)$ & $=\quad \begin{array}{c}0.063 \\
(0.039)\end{array}$ & $+\quad \begin{array}{c}0.74 \\
(0.173)\end{array}$ & $(8 / X)$ & 0.57 & $1974-84$ & 14 \\
\hline \multirow[t]{3}{*}{ rurner (1986) } & $(I / Y)$ & $\begin{array}{c}0.033 \\
(0.028)\end{array}$ & $+\quad \begin{array}{c}0.83 \\
(0.073)\end{array}$ & $(8 / Y)$ & 0.85 & $1960-74$ & 23 \\
\hline & $(I / Y)$ & $\begin{array}{cc}-0.073 \\
(0.034)\end{array}$ & $+\quad \begin{array}{c}0.72 \\
(0.153)\end{array}$ & $(B / Y)$ & 0.48 & $2975-83$ & 23 \\
\hline & $(I / Y)$ & $\begin{array}{cc}-\quad 0.102 \\
(0.012)\end{array}$ & $+\quad \begin{array}{l}0.38 \\
(0.054)\end{array}$ & $(8 / Y)$ & 0.36 & $1975-83(c)$ & 23 \\
\hline
\end{tabular}

a) I denotes domet1c invertment, eaving, I grose nat lonal or dowet1c product and ca the curront-account balance. atandard orrore are obow bolow coeflicionta. Tho $\Delta$ Indicatee change in everago ratee botween porlode.

b) Inveatment and eaving rat1es are everages over the aaple porlod.

c) IIne gearly observatione pooled. 
$\operatorname{MngR}$ III

MEASUREMANT ISSUES RELATING TO HOUSTHOLD SAVING

In the Standardized National Accounts (SNA) household saving is measured as the difference between current disbursements and current receipts. It can be regarded as the surplus on current transactions available for financing capital formation or lending abroad or to other domestic sectors. As such, saving is therefore a residual item and is affected by errors in the measurement of the two aggregates from which it is derived. Based on two important papers by Blades (1983, 1988) this section examines some of the measurement issues affecting the construction of household saving ratios and reports adjusted saving ratios for a number of countries.

In the Standardized National Accounts, the household sector includes unincorporated enterprises which consist mainly of farms, small family businesses and owners of dwellings. The relative importance of unincorporated enterprises varies across countries, as does the way they are treated in National Accounts statistics. These differences make international comparisons difficult. In particular, except in Japan, France, Italy and Finland, private non-profit institutions serving households are also included in the household sector.

To adjust gross household saving ratios for the unincorporated enterprises, it would in principle be necessary to exclude from entrepreneurial income, as well as taxes and property income, the parts which arise from "pure" business operations. In the majority of cases, the income and outlay accounts cannot easily be split and it is therefore difficult to derive a "pure" household saving ratio. The net household saving ratios which are reported in the SNA can be viewed as the household saving ratios adjusted for unincorporated enterprises by assuming that gross saving of unincorporated businesses is exactly equal to the consumption of fixed capital (including that of housing), so that their net saving is zero. However, as mentioned in section III.C.ii) of the main text, capital depreciation is difficult to evaluate both within and across countries, so that data on gross saving ratios are more reliable and more appropriate for international comparisons. The adjusted net or "pure" household saving ratios are on average between 3 to 5 percentage points lower than the gross ratios (Table A3) but generally show the same trends. Over the 1980s, the dispersion in the net ratios over the nine countries for which such an adjustment is possible is greater than in the gross ratios.

An alternative way of dealing with the problem of unincorporated enterprises is to combine households and all enterprises into one "private sector". This solution can also be justified by arguing that the level of household saving is not independent of the wealth formation in the business sector. The issue is addressed and trends in private sector saving are discussed in section III.A of the main text.

Purchases of consumer durables are treated in the SNA as final consumption expenditure. Since these goods provide services for a long period 
of time they might also be considered as capital goods rather than current expenditure. Table A3 reports household gross saving ratios when consumer durable goods have been excluded from household consumption expenditure, using the same methodology as in Blades (1983) (1). This adjustment has a marked impact in all countries. In the United States and Canada the average saving ratio is 60 per cent higher and it is more than doubled in Sweden. In Japan; on the other hand, the adjustment for consumer durables raises the average saving ratio by only 20 per cent. In general, the increases are most marked in countries with low gross saving ratios, and in these countries the adjustment tends to dampen the fluctuations over time. In the United states and Canada, for example, the decline in the household gross saving ratios recorded in the $1980 \mathrm{~s}$ is considerably reduced.

The treatment of pensions and social security schemes in the SNA may also bias measured household saving ratios. While saving by employees in private pension funds is included in household saving, this is not the case for government social security schemes. Although both serve the same purpose from the household's point of view, transactions between households and government social security systems are considered as current while those with private schemes are treated as capital transactions. The rationale for this difference reflects the view that households generally regard contributions to private pension schemes as financial investment but consider social security contributions as being of the same nature as income taxes. These different treatments make national account saving ratios difficult to interpret for comparisons between countries because the relative importance of social security and private schemes varies across countries. In principle, household saving can be adjusted either by subtracting saving from private pension and life insurance funds or by adding saving from social security schemes.

Treating private pension systems as public schemes leads to particularly large adjustments to household gross saving ratios in the United Kingdom and the United States where private pension and life insurance schemes represent a large share of the pension systems. In the first two countries, the average gross saving ratios are reduced by 60 and 40 per cent respectively in the $1980 \mathrm{~s}$ while the reduction represents only about 10 per cent in France and Sweden. Adjusting gross household saving to include saving generated by public pension schemes, is difficult because SNA statistics only provide information on saving of social security funds as a whole. Table A3 reports adjusted saving ratios when all saving reported for the social security sector is assumed to arise from pensions. As a result, household saving ratios are increased, since social security schemes generally generate positive saving (except in the United States in the late 1970s), and the adjustment is particularly large in sweden where social security contributions are substantially higher than benefits. In Canada the adjusted saving ratio averaged over the $1980 \mathrm{~s}$ is 3 percentage points higher, while in other countries the difference between the adjusted and gross saving ratios is about 1 percentage point. 
NOT:

1. Because the stock of consumer durables is not available for a number of countries, it is not possible to adjust household income for the flow of services generated by consumer durables so that a number of assumptions have to be made (see Blades, 1983). According to SNA rules the flow of services is equal to the sum of consumption of fixed capital, net operating surplus and intermediate consumption. In the calculations here it was assumed that net operating surplus is zero and that consumption of fixed consumer capital is equal to purchases of new consumer durables. The assumption implies a constant net stock of consumer durables. 
2able 23

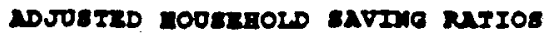

(a)

Onited states

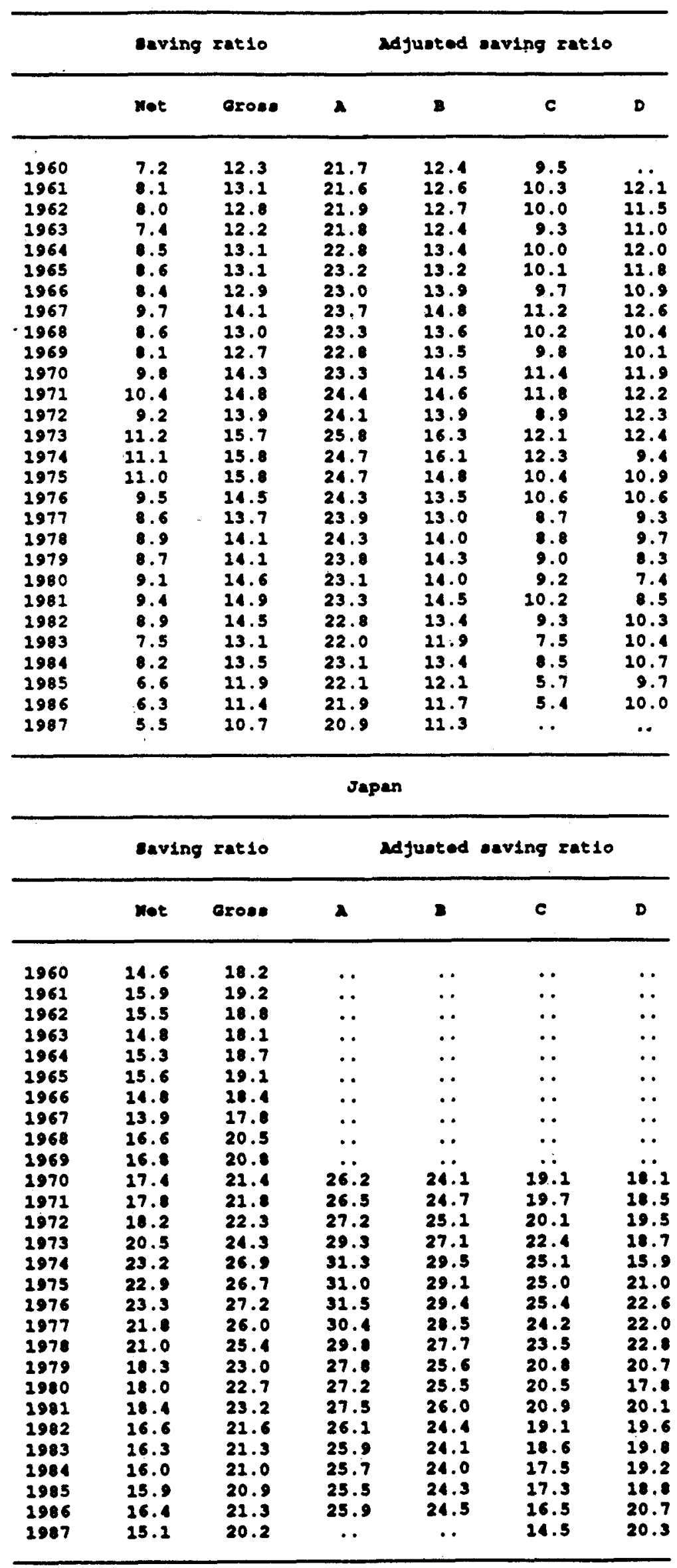


cormany

\begin{tabular}{|c|c|c|c|c|c|c|}
\hline & \multicolumn{2}{|c|}{ Saving rat 10} & \multicolumn{4}{|c|}{ Idfueted aaving ratio } \\
\hline & wot & Grone & $\boldsymbol{\lambda}$ & $\mathbf{x}$ & c & D \\
\hline 1960 & 8.6 & $\cdots$ & .. & 9.9 & .. & .. \\
\hline 1961 & 9.1 & $\ddot{x}$ & $\because$ & $\begin{array}{l}10.3 \\
10.0\end{array}$ & $\cdots$ & 7.2 \\
\hline $\begin{array}{l}1962 \\
1963\end{array}$ & $\begin{array}{l}8.6 \\
9.9\end{array}$ & $\ddot{0}$ & $\because$ & $\begin{array}{l}10.0 \\
11.1\end{array}$ & $\because$ & 6.9 \\
\hline $\begin{array}{l}1963 \\
1964\end{array}$ & 11.3 & $\because$ & $\because$ & 21.16 & $\ddot{.}$ & $\begin{array}{l}8.1 \\
9.8\end{array}$ \\
\hline 1965 & 12.2 & . & .. & 13.3 & $\because$ & 10.2 \\
\hline 1966 & 11.6 & $\cdots$ & $\cdots$ & 22.6 & .. & 9.1 \\
\hline 1967 & 21.2 & $\cdots$ & . & 10.9 & . & 9.9 \\
\hline 2968 & 12.5 & $\ldots$ & . & 12.5 & . & 11.3 \\
\hline 1969 & 23.3 & . & $\cdots$ & 13.6 & $\therefore$ & 12.8 \\
\hline 1970 & 13.8 & $\cdots$ & . & 25.1 & 11.5 & 10.9 \\
\hline 1971 & 23.5 & $\cdots$ & . & 14.9 & 21.0 & 8.8 \\
\hline 1972 & 14.4 & $\cdots$ & .. & 15.7 & 21.7 & 9.6 \\
\hline 2973 & 13.9 & $\cdots$ & . & 15.8 & 11.1 & 0.2 \\
\hline 1974 & 14.6 & $\cdots$ & $\cdots$ & 25.1 & 12.6 & 7.9 \\
\hline 1975 & 15.1 & . & . & 14.7 & 22.3 & 9.2 \\
\hline 1976 & 13.3 & $\cdots$ & $\cdots$ & 13.3 & 10.3 & 9.0 \\
\hline 2977 & 22.2 & . & . & 11.8 & 9.2 & 8.3 \\
\hline 1978 & 12.0 & $\cdots$ & . & 11.9 & 8.8 & 9.1 \\
\hline 1979 & 12.6 & $\ldots$ & . & 12.7 & 9.2 & 8.3 \\
\hline 1980 & 12.8 & . & $\ldots$ & 13.2 & 9.2 & 6.2 \\
\hline 1981 & 23.4 & . & . & 14.1 & 9.8 & 6.2 \\
\hline 1982 & 12.8 & . & . & 13.6 & 9.3 & 6.8 \\
\hline 1983 & 10.9 & . & . & 11.1 & 7.1 & 6.6 \\
\hline 1984 & 11.4 & $\ldots$ & $\ldots$ & 11.6 & 7.5 & 8.0 \\
\hline 1985 & 11.4 & .. & .. & 12.0 & 7.4 & 8.6 \\
\hline 1986 & 12.2 & . & $\ldots$ & 13.2 & 8.2 & 12.8 \\
\hline \multirow[t]{4}{*}{1987} & 12.4 & . & . & 13.1 & 0.5 & 21.6 \\
\hline & \multicolumn{6}{|c|}{ Irance } \\
\hline & \multicolumn{2}{|c|}{ saving rat 10} & \multicolumn{4}{|c|}{ adjusted eaving ratio } \\
\hline & Not & Grose & $\mathbf{x}$ & B & c & D \\
\hline 1960 & $21: .6$ & .. & .. & $\cdots$ & $\cdots$ & $\cdots$ \\
\hline 1961 & 21.0 & . & . & . & . & $\cdots$ \\
\hline 1962 & 13.5 & . & .. & . & $\cdots$ & $\cdots$ \\
\hline 1963 & 12.4 & . & .. & $\cdots$ & $\cdots$ & $\cdots$ \\
\hline 1964 & 12.2 & . & . & . & $\cdots$ & $\cdots$ \\
\hline 1965 & 12.8 & . & . & $\cdots$ & $\cdots$ & $\cdots$ \\
\hline 1966 & 12.3 & $\cdots$ & $\cdots$ & $\cdots$ & .. & .. \\
\hline 1967 & 12.6 & . & . & . & . & .. \\
\hline 1968 & 12.4 & . & . & . & $\cdots$ & $\cdots$ \\
\hline 1969 & 11.0 & . & $\cdots$ & . & . & .. \\
\hline 1970 & 23.0 & 18.8 & 24.7 & 19.9 & . & 17.1 \\
\hline 2971 & 13.6 & 18.3 & 24.6 & 19.4 & .. & 16.2 \\
\hline 1972 & 13.7 & 18.9 & 25.5 & 19.9 & . & 16.5 \\
\hline 1973 & 14.2 & 19.2 & 26.0 & 19.9 & . & 16.5 \\
\hline 2974 & 14.2 & 19.8 & 26.3 & 20.6 & . & 24.5 \\
\hline 2975 & 15.4 & 20.3 & 26.8 & 21.1 & .. & 16.2 \\
\hline 1976 & 13.0 & 18.3 & 25.7 & 19.5 & . & 14.4 \\
\hline 1977 & 13.3 & 18.7 & 26.0 & 19.8 & 18.3 & 15.0 \\
\hline 1970 & 14.2 & 20.4 & 27.6 & 20.7 & 20.0 & 16.8 \\
\hline 2979 & 12.8 & 18.9 & 26.2 & 19.8 & 28.4 & 14.3 \\
\hline $\begin{array}{l}1980 \\
1981\end{array}$ & $\begin{array}{l}12.5 \\
12.4\end{array}$ & $\begin{array}{l}17.7 \\
18.1\end{array}$ & $\begin{array}{l}25.0 \\
25.2\end{array}$ & $\begin{array}{l}19.0 \\
18.3\end{array}$ & $\begin{array}{l}27.1 \\
27.5\end{array}$ & $\begin{array}{l}11.9 \\
12.7\end{array}$ \\
\hline 1982 & 12.4 & 17.4 & 25.0 & 27.6 & 16.8 & 12.8 \\
\hline 2983 & 11.0 & 16.1 & 23.4 & 27.0 & 25.3 & 12.9 \\
\hline 1984 & 10.1 & $\begin{array}{l}14.7 \\
14.0\end{array}$ & $\begin{array}{l}21.4 \\
20.6\end{array}$ & $\begin{array}{l}13.6 \\
14.7\end{array}$ & $\begin{array}{l}13.7 \\
12.7\end{array}$ & $\begin{array}{l}11.1 \\
11.3\end{array}$ \\
\hline $\begin{array}{l}1985 \\
1986\end{array}$ & $\begin{array}{l}9.0 \\
. .\end{array}$ & $\begin{array}{l}14.0 \\
13.5\end{array}$ & $\begin{array}{l}20.6 \\
20.6\end{array}$ & $\begin{array}{l}14.7 \\
23.4\end{array}$ & $\begin{array}{l}12.7 \\
11.8\end{array}$ & 12.2 \\
\hline 1987 & 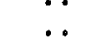 & 12.2 & 29.7 & 12.7 & 10.2 & 10.7 \\
\hline
\end{tabular}


onsted Kingdon

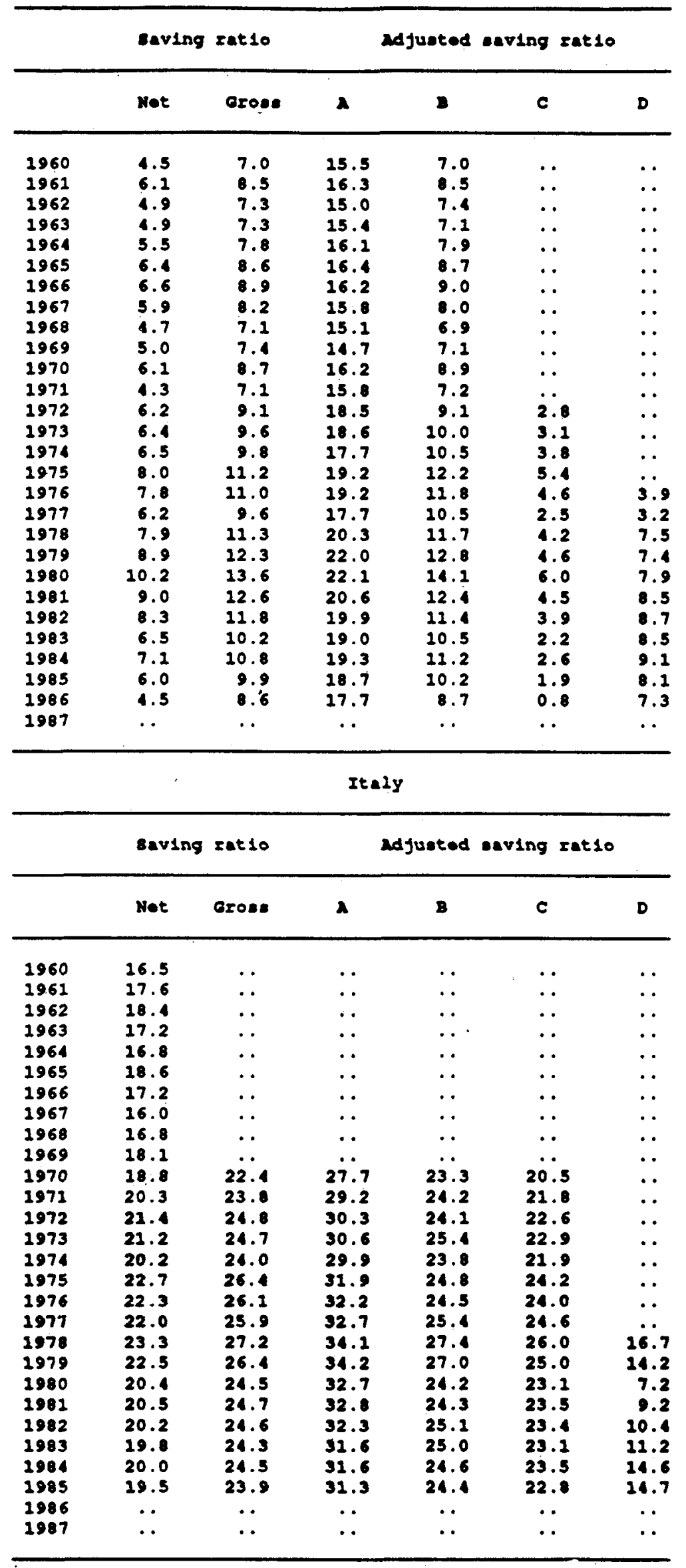


censede

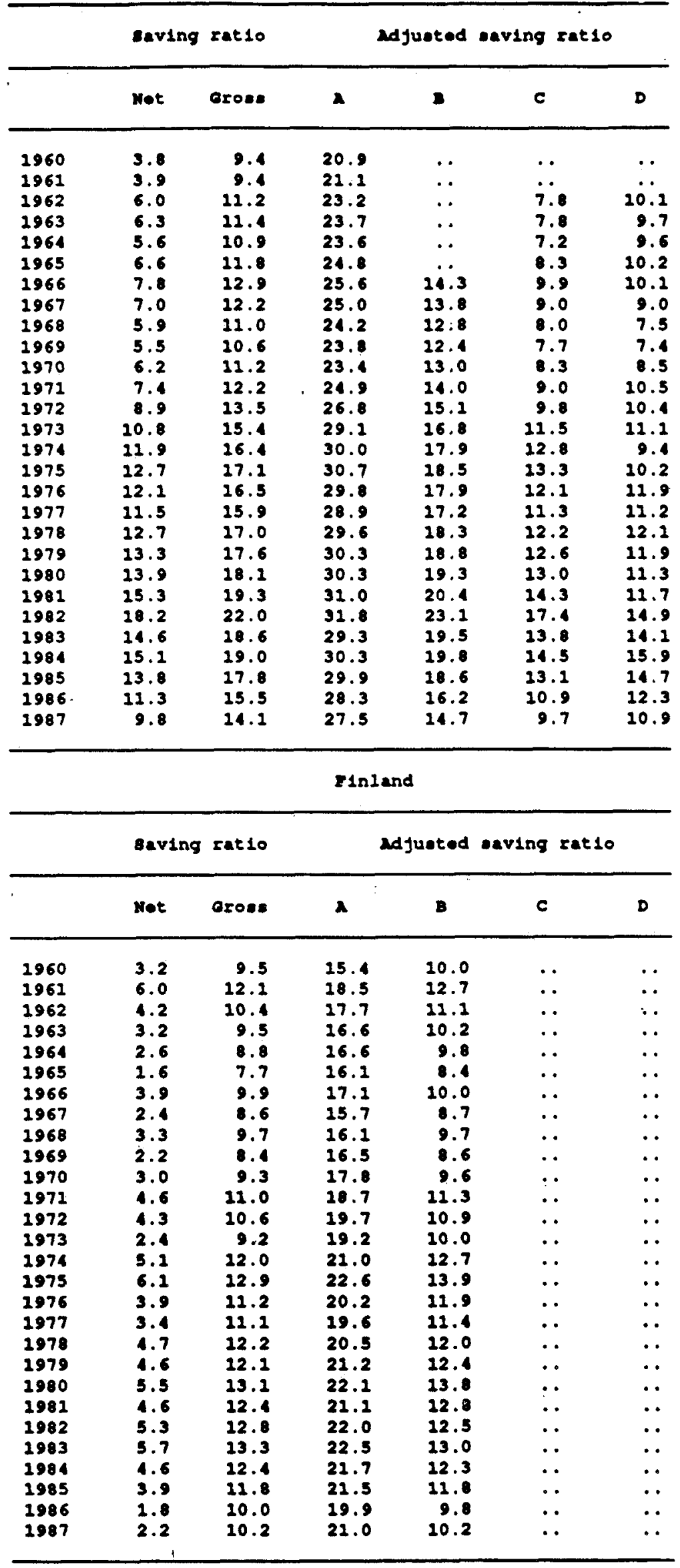


owodon

\begin{tabular}{|c|c|c|c|c|c|c|}
\hline & \multicolumn{2}{|c|}{ saving rat 10} & \multicolumn{4}{|c|}{ Idjueted eaving rat10 } \\
\hline & not & Eroea & $\mathbf{x}$ & $\mathbf{2}$ & c & $\mathbf{D}$ \\
\hline 1960 & 7.7 & 11.1 & . & - & . & $\cdots$ \\
\hline 1961 & 7.4 & 20.7 & . & . & - & . \\
\hline 1962 & 7.4 & 20.7 & . & .. & . & . \\
\hline 1963 & 5.5 & 10.0 & . & . & . & . \\
\hline 1964 & 7.9 & 22.2 & .. & $\cdots$ & $\cdots$ & $\cdots$ \\
\hline 1965 & 6.3 & 10.7 & . & - & $\cdots$ & $\cdots$ \\
\hline 1966 & 6.3 & 10.8 & . & - & $\cdots$ & - \\
\hline 1967 & 5.4 & 9.8 & .. & .. & . & . \\
\hline 1968 & 4.4 & 8.8 & .. & . & $\cdots$ & .. \\
\hline 1969 & 4.2 & 8.3 & $\therefore$ & $\therefore$ & 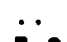 & . \\
\hline 1970 & 4.2 & 8.3 & 17.4 & 24.3 & 7.2 & . \\
\hline 1971 & 4.4 & 8.4 & 27.3 & 24.9 & 7.2 & . \\
\hline 1972 & 2.6 & 6.7 & 16.2 & 13.8 & 5.4 & . \\
\hline 1973 & 4.0 & 0.1 & 17.7 & 14.6 & 6.8 & . \\
\hline 1974 & 5.3 & 9.3 & 19.5 & 25.4 & 8.2 & . \\
\hline 1975 & 5.0 & 9.0 & 19.5 & 24.8 & 7.7 & $\cdots$ \\
\hline $\begin{array}{l}2976 \\
1977\end{array}$ & 2.7 & 6.9 & 17.8 & 13.2 & 5.8 & $\cdots$ \\
\hline 1977 & 4.3 & 8.6 & 18.3 & 14.5 & 7.7 & . \\
\hline 1978 & 4.8 & 9.2 & 18.3 & 14.7 & 0.3 & . \\
\hline 1979 & 3.2 & 7.8 & 27.1 & 13.0 & 6.8 & . \\
\hline 2980 & 5.2 & 9.8 & 28.2 & 14.6 & 8.9 & . \\
\hline 1981 & 4.0 & 8.8 & 26.9 & 13.7 & 7.7 & . \\
\hline 1982 & 0.8 & 5.8 & 14.5 & 10.5 & 4.5 & $*$ \\
\hline 1983 & 1.4 & 6.5 & 14.7 & 10.8 & 4.3 & . \\
\hline 1984 & 1.1 & 6.3 & 14.6 & 21.0 & 4.2 & . \\
\hline 1985 & 1.3 & 6.2 & 14.4 & 20.3 & 4.0 & . \\
\hline 1986 & -0.5 & 4.4 & 13.8 & 8.7 & 1.3 & . \\
\hline 2987 & . & . & $\ldots$ & $\therefore$ & $\cdots$ & - \\
\hline
\end{tabular}

a) A: Grose bouebhold eaving rat10 adjusted for convumer durablee,

B: Groes bousbold eaving ratio adfueted for sociel accurity funds,

c: Grose bousebold saving ratio adjueted for private ponsion schome and 11 e inourance funde,

D: Groas bousebold eaving ratio adjueted for inflation. 


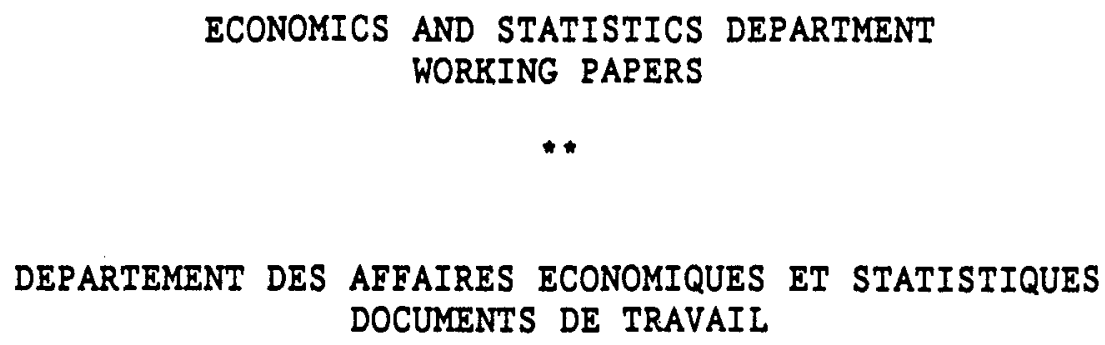

DOCUMENTS DE TRAVAIL

In April 1983, the Economics and Statistics Department initiated a new series of economic studies entitled ESD Working Papers.

The following titles have been circulated:

1. Use of Demand Elasticities in Estimating Energy Demand (out of print) Utilisation des Elasticités de la Demande dans l'Estimation de la Demande de 1'Energie

Axel Mittelstadt

2. Capital, Energy and Labour Substitution: the supply block in OECD medium-term models

Substitution du Capital, de l'Energie et du Travail : le bloc de 1 'offre dans les modèls à moyen terme de 1'OCDE (épuisé)

Patrick Artus

3. Wage Formation in France: sectoral aspects (out of print)

Formation des Salaires en France : aspects sectoriels (épuisé)

Patrick Artus

4. Service Lives of Fixed Assets (out of print)

Durée de Vie Utile des Actifs Fixes (épuisé)

Derek Blades

5. Resource Prices and Macroeconomic Policies: Lessons from Two Oil

Price Shocks

Prix des Ressources Naturelles et Politique Macro-Economique : Les Enseignements de Deux Chocs Pétroliers (épuisé)

John Llewellyn

6. Output Responsiveness and Inflation: An Aggregate Study Souplesse de la Production et Inflation : Etude Globale

David T. Coe and Gerald Holtham 
7. The Determinants of Exchange Rate Movements (out of print) Les Déterminants des Mouvements des Taux de Change (épuisé)

Graham Hacche

8. Simulated Macroeconomic Effects of a Large Fall in Oil Prices (out of print)

Simulation des Effets Macro-économiques d'une Forte Baisse des Prix Pétroliers

Elemming Larsen and John Llewellyn

9. Medium-Term Financial Strategy: The Co-ordination of Eiscal Monetary Policy (out of print)

Stratégie Financière à Moyen Terme : la Coordination des Politiques Monétaire et Budgétaire (épuisé)

Jean-Claude Chouraqui and Robert Price

10. Price Dynamics and Industrial Structure: A Theoretical and Econometric Analysis (out of print)

Dynamique des Prix et Structure Industrielle : Une analyse théorique économétrique (épuisé)

David Encaoua (with collaboration from Paul Geroski and Riel Miller

11. Evidence on Income Distribution by Governments (out of print)

L'Action Exercée par 1'Etat sur la Redistribution du Revenu

Peter Saunders

12. Labour Force Participation: An Analysis with Projections Taux d'Activité : Analyse et Projections

James H. Chan-Lee

13. The Demand for Money and Velocity in Major OECD Countries (out of print)

La Demande de Monnaie et la Vitesse de Circulation dans les Grands Pays de 1'OCDE

A. Blundel1-Wignal1, M. Rondoni and H. Ziegelschmidt

14. The Conduct of Monetary Policy in the Current Recovery La Conduite de la Politique Monétaire dans la Phase Actuelle de Reprise Economique

Paul Atkinson and Jean-Claude Chouraqui

15. Structural Budget Deficits and Fiscal Stance (out of print)

Déficits Budgétaires Structurels et Orientation de la Politique Budgétaire (épuisé)

Patrice Muller and Robert W.R. Price 
16. Monetary Policy in the OECD Interlink Model La Politique Monétaire dans le Modèle Interlink

A. Blundell-Wignall, M. Rondoni, H. Ziegelschmidt and J. Morgan

17. Real Gross Product in OECD Countries and Associated Purchasing Power Parities (out of print)

Produit Brut Réel et Parités de Pouvoir d'Achat dans les pays de 1'OCDE (épuisé)

Peter Hill

18. The OECD Compatible Trade and Production Data Base (out of print) Base de Données Compatibles sur le Commerce et la Production de I'OCDE

Derek Blades and Wendy Simpson

19. Nominal Wage Determination in Ten OECD Economies

Détermination des Salaires Nominaux dans Dix Economies de 1'OCDE

David T. Coe and Francesco Gagliardi

20. Profits and Rates of Return in OECD Countries

Profits et Taux de Rendement dans les Pays Membres de 1'OCDE

James H. Chan-Lee and Helen Sutch

21. Real Interest Rates and the Prospects for Durable Growth

Taux d'Intérêt Réels et Perspectives de Croissance Durable

Paul Atkinson and Jean-Claude Chouraqui

22. Energy Prices: Trends and Prospects

Les Prix de l'Energie : Evolution et Perspectives

Axel Mittelstadt

23. Changes in the Composition of Output and Employment

Changements dans la Composition de la Production et de 1'Emploi

Axel Mittelstadt and Françoise Correia

24. Labour Market Flexibility and External Price Shocks

Flexibilité du Marché du Travail et Chocs Extérieurs sur les Prix

F. Klau and A. Mittelstadt

25. Discrepancies Between Imports and Exports in OECD Foreign Trade Statistics (out of print)

Ecart entre les Importations et les Exportations dans les Statistiques du Commerce Extérieur de 1'OCDE

Derek Blades and Marina Ivanov 
26. Aggregate Supply in Interlink: Model Specification and Empirical Results

John Helliwe11, Peter Sturm, Peter Jarrett and Gérard Salou

27. Commodity Prices in Interlink

Gerry Holtham, Tapio Saavalainen, Paul Saunders and Helen Sutch

28. Exchange Rates and Real Long-Term Interest Rate Differentials:

Evidence for Eighteen OECD Countries

David T. Coe and Stephen S. Golub

29. Method of Calculating Effective Exchange Rates and Indicators of Competitiveness (out of print)

Martine Durand

30. Public Debt in a Medium-Term Context and its Implications for Fiscal Policy

Jean-Claude Chouraqui, Brian Jones and Robert Bruce Montador

31. The OECD Compatible Trade and Production Data Base 1970-1983

Anders Brodin and Derek Blades

32. The Formulation of Monetary Policy: A Reassessment in the Light of Recent Experience

Paul Atkinson and Jean-Claude Chouraqui

33. Mécanismes de Transmission et Effets Macro-Economiques de la Politique Monétaire en France : les Principaux Enseignements Econométriques

Marc-Olivier Strauss-Kahn

34. Pure Profit Rates and Tobin's $q$ in Nine OECD Countries

James H. Chan-Lee

35. Wealth and Inflation Effects in the Aggregate Consumption Function G.H. Holtham and H. Kato

36. The Government Household Transfer Data Base

Rita Varley 
37. Internationalisation of Financial Markets: Some Implications for Macroeconomic Policy and for the Allocation of Capital

Mitsuhiro Fukao and Masaharu Hanazaki

38. Tracking the US External Deficit, 1980-1985: Experience with the OECD Interlink Model

Pete Richardson

39. Monetary Policy in the Second Half of the 1980s: How Much Room For Manoeuvre?

Kevin Clinton and Jean-Claude Chouraqui

40. Tax Reform in OECD Countries: Economic Rationale and Consequences Bob Hagemann, Brian Jones and Bruce Montador

41. A Revised Supply Block for the Major Seven Countries in Interlink Peter Jarrett and Raymond Torres

42. OECD Economic Activity and Non-0il Commodity Prices: Reduced-Form Equations for INTERLINK

Gerald Holtham and Martine Durand

43. Import and Export Price Equations for Manufactures

Richard Herd

44. Price Determination in the Major Seven Country Models in INTERLINK Ulrich Stiehler

45. International Investment-Income Determination in INTERLINK: Models for 23 OECD Countries and Six Non-OECD Regions

David T. Coe, Richard Herd and Marie-Christine Bonnefous

46. Recent Developments in OECD's International Macroeconomic Model

Pete Richardson

47. A Review of the Simulation Properties of OECD's INTERLINK Model Pete Richardson

48. The Medium-Term Macro-Economic Strategy Revisited Jean-Claude Chouraqui, Kevin Clinton and Robert Bruce Montador

49. Are Commodity Prices Leading Indicators of OECD Prices?

Martine Durand, Sveinbjörn Blöndal 
50. Private Consumption. Inflation and the "Debt Neutrality Hypothesis" The case of Eight OECD Countries

Giuseppe Nicoletti

51. The Effects of Monetary Policy on the Real Sector: An overview of Empirical Evidence for Selected OECD Economies

Jean-Claude Chouraqui, Michael Driscoll and Marc Olivier Strauss-Kahn

52. The So-Called "Non-Economic" Objectives of Agricultural Policy

\section{Alan Winters}

53. Alternative Solution Methods in Applied General Equilibrium Analysis

Richard G. Harris

54. Tests of Total Factor Productivity Measurement
A. Steven Englander

55. Quantifying the Economy-Wide Effects of Agricultural Policies: A General Equilibrium Approach

Jean-Marc Burniaux, François Delorme, Ian Lienert, John P. Martin and Peter Hoeller

56. On Aggregation Methods of Purchasing Power Parities

J.R. and M. Cuthbert

57. An International Sectoral Data Base for Thirteen OECD Countries

F.J.M. Meyer-zu-Schlochtern

58. Empirical Research on Trade Liberalisation with Imperfect Competition: A Survey.

J. David Richardson

59. Eliminating the US Federal Budget Deficit by 1993: the Interaction of Monetary and Fiscal Policy

$R$. Herd and B. Ballis

60. Compatible Trade and Production Data Base: 1970-1985

Claude Berthet-Bondet, Derek Blades and Annie Pin 
61. Ageing Populations: Implications for Public Finances Robert P. Hagemann, Giuseppe Nicoletti

62. The Economic Dynamics of an Ageing Population: the Case of Four OECD Economies

Alan J. Auerbach, Laurence J. Kotlikoff, Robert P. Hagemann, Giuseppe Nicoletti

63. Modelling Housing Investment for Seven Major OECD Countries Thomas Egebo and Ian Lienert

64. Revised Groupings for non-OECD Countries in OECD's macroeconomic mode1 INTERLINK

Paul O'Brien, Laure Meuro, Arthur Camilleri

65. A post mortem on OECD short-term projections from 1982 to 1987 Byron Ballis

66. Potential Output in the Seven Major OECD Countries Raymond Torres and John P. Martin 